


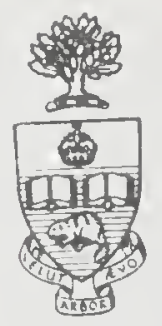

Presented to the

LIBRARY of the

UNIVERSITY OF TORONTO

by

The Estate of

N. Roy Clifton 


$$
\begin{aligned}
& x_{x=2}= \\
& \text { 1.2 }= \\
& \text { o4i }
\end{aligned}
$$


Digitized by the Internet Archive in 2020 with funding from University of Toronto 


\section{"Great Volriters."}

EDITED BY

PROFESSOR ERIC S. ROBERTSON, M.A.,

LIFE OF DARIVIN. 



\section{I F E}

OF

\section{CHARLES DARWIN}

G. T. BETTANY

921

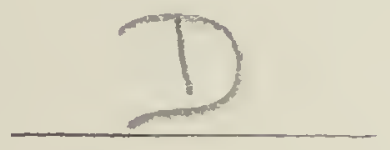

cat

LONDON :

IV A L T ER SCOT T, LIM ITE D,

24 WARWICK LANE. 



\section{CONTENTS.}

\section{CHAPTER I.}

Darwin's ancestry; his grandfather, Dr. Erasmus Darwin, a successful physician, and author of "The Botanic Garden," "The Temple of Nature," \&c. ; his father, Robert Waring Darwin, also a successful physician; his maternal grandfather, Josiah Wedgwood, the celebrated potter; his mother's education and training; Charles Robert Darwin, born at Shrewsbury, Feb. I2, I809; Mrs. Darwin dies in July, I8I7; her eldest son, Erasmus, friend of the Carlyles; Charles Darwin's education by Mr. Case, and at Shrewsbury Grammar School ; his character as a boy ; is sent to Edinburgh University in 1825 . . .

\section{CHAPTER II.}

Darwin a member of the Plinian Society, of Edinburgh; makes natural history excursions; his first scientific paper read March, 27, 1827 ; friendship with Dr. Grant ; Jameson's lectures on zoology ; Darwin enters Christ's College, Cambridge, in I828; his friendship with Prof. Henslow; his account of Henslow; Darwin at this time specially an entomologist; his excursions with Henslow; takes B.A. degree in 1831 , M.A. in 1837 ; voyage of Beagle proposed, and Darwin appointed as naturalist; the Beagle sails on Dec. 27, 1831; Darwin's letters to Henslow published 1835; 1832, Darwin at Teneriffe, Cape de Verde Islands, St. Paul's Rocks, Bahia, Rio de Janeiro (April); excursions into interior and amusing adventures; his experiences and horror of slavery; at Monte Video, July ; Maldonado, 
Rio Negro; visit to Tierra del Fuego, Dec. I832-Jan. I833; rencontre with General Rosas; many extinct animals discovered; Buenos Ayres, Sept. I833; excursion to Santa Fé; Port Desire, Dec. I $\$ 33$; Port St. Julian, Jan. I 834 ; Valparaiso, July I 834 ; expeditions to the Andes, Santiago, \&c. ; Chiloe, Nov. I834; the Chonos Archipelago, Dec. I834; Valdivia, Feb. I835; an earthquake experience; expedition across the Cordillera in March, I835; voyage across the Pacific commenced in September ; the Galapagos Archipelago and its interesting animals; Tahiti, Nov. I835; Darwin's opinion of English products, and of the influence of Christian missionaries; New Zealand, Dec. I835; Port Jackson, Jan. I836 ; Tasmania, Feb. ; the Keeling Islands, April ; the homeward journey; Falmouth reached, Oct. 2, I836 ; Capt. Fitzroy's opinion of Darwin ; Darwin's first impression of savages

\section{CHAPTER III.}

Darwin elected F.G.S. ; Lyell's high opinion of him; secretary of the Geological Society, Feb. I838-4I; reads numerous papers before the Society; elected F.R.S., Jan. 24, I839; marries his cousin, Miss Wedgwood, early in I S39 ; "Journal of Researches," published I839, highly praised in Quarterly Revieww ; publication of zoology of the Beagle (IS39-43); extraordinary animals described therein; other results of the voyage ; plants described by Hooker and Berkeley; work on "Coral Reefs" published I 842; Darwin's new theory at once accepted; subsequent views of Semper, Dana, and Murray ; second and third parts of Geology of Beagle ("Volcanic Islands" and "South America "); other geological papers; Darwin settles at Down House, near Beckenham, I842; appears at Oxford meeting of British Association, I847; contributes chapter on Geology to Herschel's manual of Scientific Enquiry; publishes great works on recent and fossil cirripedia, I85I-4; receives Royal Medal of Royal Society, I 853 , and Wollaston Medal of Geological Society, I 859

\section{CHAPTER IV.}

Confusion in description of species; labours of Professors Owen and Huxley; Darwin's ideas on the origin of species germinated during the voyage of the Beagle; he collected facts, 
I 837-42; drew up a sketch, I 842 ; cnlargcd it in I844; previous speculations on the subject; views of Erasmus Darwin, Geoffroy St. Hilaire, and Lamarck; Darwin's opinion of Lamarck; influence of Lyell ; influence of South American experience; reads Malthus on Population ; "Vestiges of Creation"; Mr. Herbert Spencer and evolution; Lyell's lettcrs; Sir Joseph Hooker on species; Mr. A. R. Wallace communicates his vicws to Darwin; Lyell and Hooker persuade Darwin to publish his views together with those of Wallace; introductory letter by Lyell and Hooker to Linnean Society, June 30, IS58; Darwin's and Wallace's papers, read July I, I858; Sir J. Hooker announces his adhesion to Darwin's views, I859.

\section{CHAPTER V.}

Analysis of the "Origin of Species," published Nov. I859; special notes of Darwin's personal experiences; remarkable growth of morphology and embryology since its publication; opposition to the new views; criticisms of leading journals and reviews ; second edition of "Origin," called for in six wecks; third, in March I86I ; historical sketch of progress of opinion prefixed; alterations in successive editions; sixth edition, I872; foreign translations

\section{CHAPTER VI.}

Darwin's physical appearance, habits, distinguished visitors; his kindliness; attachment of friends; his family; he reads important botanical papers before the Linnean Society ; publishes the "Fertilisation of Orchids," I S62 ; analysis of the book; Darwin receives Copley Medal of Royal Society, I 864 ; "Movements and Habits of Climbing Plants," I 865 ; "Variation of Animals and Plants under Domestication," I868 ; the hypothesis of pangenesis not favourably received.

\section{CHAPTER VII.}

"The Descent of Man," I87 I ; Darwin's varied use of personal experiences; his views on the differences between mon and women; his views on happiness and its promotion in mankind ; reception of the "Descent of Man"; Punch, the Quarterlies, The Saturday Review 
CHAPTER VIII.

"Expression of the Emotions," I872; Darwin's methods of studying the question; his personal experiences; studies of children; reminiscences of South American travel; studies of monkeys; his wide study of novels; his influence on mental science

\section{CHAPTER IX.}

"Insectivorous Plants," I 875; how Darwin was led to study them; analysis of the book; "Effects of Cross and SelfFertilisation," I 876 ; competitive germination and growth ; "The Different Forms of Flowers," I877; "The Power of Movement in Plants," I880 . . . . . .

\section{CHAPTER X.}

Honours bestowed on Darwin; his reception at Cambridge in I877; portraits by Richmond and Collier; Haeckel's and De Candolle's descriptions of visits to Darwin; "The Formation of Vegetable Mould by Earthworms," I88I ; the long series of experiments on which it was based; obligations of archæologists to worms ; gradual exhaustion in I882; his death on April I9, I882

\section{CHAPTER XI.}

Darwin buried in Westminster Abbey, April 26, I882; quotation from The Times; subscriptions to Darwin memorial; large number of subscriptions from Sweden; statue exe. cuted by Mr. Boehm, placed in Museum of Natural History, South Kensington, unveiled by Prince of Wales, June 9, I885; remainder of fund handed to Royal Society to promote biological research; The Saturday Revieze on Darwin; his geniality and humour; his influence on others; his lack of prejudice; extracts from his letters; letter on experiments on living animals; Darwin as an experimenter ; his attitude towards Christianity and revela. tion; his literary style; his imagination ; Prof. Huxley on Darwin; Dr. Masters on his influence on horticulture; Messrs. Sully and Winchell on his philosophy; conclusion 154 


\title{
NOTE.
}

\begin{abstract}
ARWIN revealed himself so largely in his books, that a vivid picture of much of his life can be extracted from them. Thus it has been found possible to combine much biographical interest with sketches of his most important works. Like other biographers of Darwin, I am much indebted to Mr. Woodall's valuable memoir, contributed to the Transactions of the Shropshire Archæological Society. But original authorities have been consulted throughout, and the first editions of Darwin's books quoted, unless the contrary is explicitly stated. I am greatly obliged to Messrs. F. Darwin and G. J. Romanes for kindly permitting me to quote from $\mathrm{Mr}$. Darwin's letters to Mr. Romanes. I must also express my thanks to my friends, Mr. Romanes and Prof. D'Arcy W. Thompson, for doing me the great service of looking over the proof-sheets of this book.
\end{abstract}





\section{LIFE OF DARWIN.}

\section{CHAPTER I.}

T $\mathrm{F}$ ever a man's ancestors transmitted to him ability 1 to succeed in a particular field, Charles Darwin's did. If ever early surroundings were calculated to call out inherited ability, Charles Darwin's were. If ever a man grew up when a ferment of thought was disturbing old convictions in the domain of knowledge for which he was adapted, Charles Darwin did. If ever a man was fitted by worldly position to undertake unbiassed and long-continued investigations, Charles Darwin was such a man. And he indisputably found realms waiting for a conqueror. Yet Darwin's achievements far transcend his advantages of ancestry, surroundings, previous suggestion, position. He stands magnificently conspicuous as a genius of rare simplicity of soul, of unwearied patience of observation, of striking fertility and ingenuity of method, of unflinching devotion to and belief in the efficacy of truth. He revolutionised not merely half-adozen sciences, but the whole current of thinking men's mental life.

The Darwins were originally a Lincolnshire family of some position, and being royalists suffered heavy losses 
under the Commonwealth. The third William Darwin (born 1655), whose mother was a daughter of Erasmus Earle, serjeant-at-law, ${ }^{\mathbf{1}}$ married the heiress of Robert Waring, of Wilsford, Notts, who also inherited the manor of Elston, near Newark, in that county, which still remains in the family. Robert Darwin, second son of this William Darwin, succeeded to the Elston estate, and was described by Stukeley, the antiquary, as "a person of curiosity," an expression conveying high commendation. His eldest son, Robert Waring Darwin, studied botany closely, and published a "Principia Botanica," which reached a third edition; but his youngest son, Erasmus, born I 73I, was destined to become the first really famous man of the family.

Erasmus Darwin's personal characteristics, his medical talents, and his poetic writings were such as to overshadow, for his own generation, his scientific merit. We have not space here to describe his career and his works, which has been so well done by his grandson, and by Ernst Krause ("Erasmus Darwin," I 879). Horace Walpole regarded his description of creation in "The Botanic Garden" (part i., canto I, lines I03-I I4) as the most sublime passage in any language he knew: and The Edinburgh Reviezer (vol. ii., 1803, p. 501) says of his "Temple of Nature" : "If his fame be destined in anything to outlive the fluctuating fashion of the day, it is on his merit as a poet that it is likely to rest; and his reveries

" This is the Erasmus Earle who forms the subject of " A Lawyer's Love Letters," in The National Review, February, 1887. Letters of his are also printed in the Tenth Report of the Historical MSS. Commission. 
in science have probably no other chance of being saved from oblivion but by having been 'married to immortal verse.'"

The present age regards it as next to impossible to write science in poetry; although few have succeeded better in the attempt than Erasmus Darwin. It is singular that he should have partially anticipated his illustrious grandson's theories, but without supporting them by experimental proof or by deep scientific knowledge. Suffice it to say now, that Erasmus contemplated to a great extent the same domain of science as Charles Darwin, having also a mechanical turn ; and was educated at Edinburgh and Cambridge. His observations on Providence in 1754 , when only twenty-three, in commenting on his father's death, are very interesting to compare with his grandson's attitude: "That there exists a superior Ens Entium, which formed these wonderful creatures, is a mathematical demonstration. That $\mathrm{He}$ influences things by a particular providence is not so evident. The probability, according to my notion, is against it, since general laws seem sufficient for that end. . . . The light of Nature affords us not a single argument for a future state : this is the only one, that it is possible with God, since $\mathrm{He}$ who made us out of nothing can surely re-create us; and that $\mathrm{He}$ will do this we humbly hope." $\mathrm{He}$ published an ode against atheism, with which he has strangely enough often been charged, beginning-

"Dull atheist, could a giddy dance

Of atoms lawless hurl'd

Construct so wonderful, so wise,

So harmonised a world ?" 
and his moral standpoint is shown by the declaration that "the sacred maxims of the author of Christianity, 'Do as you would be done by,' and 'Love your neighbour as yourself,' include all our duties of benevolence and morality; and if sincerely obeyed by all nations, would a thousandfold multiply the present happiness of mankind" ("Temple of Nature," I803, p. I 24). His principal poetical writings were "The Botanic Garden," in two parts; Part I. containing "The Economy of Vegetation," first published in I790; and Part II., "The Loves of the Plants," in I 788 , before the first part had appeared. "The Temple of Nature, or the Origin of Society," was published after his death, in 1803 . His chief prose works are "Zoonomia, or the Laws of Organic Life," in two volumes, I 794-6, the second volume being exclusively medical ; and "Phytologia, or the Philosophy of Agriculture and Gardening," I800. All these books are in quarto, with plates. His views on species are referred to on pages 66 and 67 .

Robert Waring Darwin, third son of Erasmus by his first wife, Mary Howard, waś born in I 766. As a boy he was brought much into association with the Wedgwoods of Stoke, Josiah Wedgwood being one of Erasmus Darwin's most intimate friends. In I 779 Robert, already destined to be a doctor, stayed at Etruria for some time, sharing with Wedgwood's children in Warltire's private chemical instruction; and Josiah Wedgwood wrote at this time: "The boys drink in knowledge like water, with great avidity." Before he was twenty Robert Darwin had taken his medical degree with distinction at Edinburgh, where he had the advantage of the lectures of 
Black, Cullen, and Gregory, and had also studied at Leyden, and travelled in Germany. In I 786 his father set him up in practice at Shrewsbury, leaving him with twenty pounds, which was afterwards supplemented by a similar sum from his uncle, John Darwin, Rector of Elston. On this slender capital he contrived to establish himself, in spite of severe competition; and his burly form and countenance, as he sat in his invariable yellow chaise, became well known to every man, woman, and child around Shrewsbury for many miles. Before long, no one thought of sending to Birmingham for a consultant, and Dr. Darwin was for many years the leading Shropshire physician, and accumulated an abundant fortune.

According to his son Charles, Robert Darwin "did not inherit any aptitude for poetry or mechanics, nor did he possess, as I think, a scientific mind. He published, in vol. Ixxvi. of the 'Philosophical Transactions,' a paper on Ocular Spectra, which Wheatstone told me was a remarkable production for the period; but I believe that he was largely aided in writing it by his father. He was elected a Fellow of the Royal Society in I788. I cannot tell why my father's mind did not appear to me fitted for advancing science, for he was fond of theorising, and was incomparably the most acute observer whom I ever knew. But his powers in this direction were exercised almost wholly in the practice of medicine and in the observation of human character. He intuitively recognised the disposition or character, and even read the thoughts, of those with whom he came into contact, with extraordinary astuteness. This skill partly accounts for his great 
success as a physician, for it impressed his patients with belief in him; and my father used to say that the art of gaining confidence was the chief element in a doctor's worldly success."

Sensitive, sociable, a good talker, high-spirited and somewhat irascible, a man who admitted no one to his friendship whom he could not thoroughly respect, the friend of the poor, prescribing gratuitously to all who were needy, pre-eminent for sympathy, which for a time made him hate his profession for the constant suffering it brought before his eyes-such was Charles Darwin's father. Miss Meteyard, in her "Group of Englishmen," I87 I, gives a vivid picture of the old doctor, his acknowledged supremacy in Shrewsbury, his untiring activity and ubiquity, his great dinner parties, his liberal and rather unpopular opinions, tolerated for the sake of his success in curing his patients. His face, powerful, unimpassioned, mild, and thoughtful, was always the same as he rolled through the streets and lanes, for he sat "as though carved in stone." His love of children was marked. "He would address them in his small, high-pitched falsetto voice, and if their answers pleased him he would reply; and occasionally, lifting them on to a chair or table, he would measure their heads with his broad hand, as though reading character, and mentally prognosticating their future fate."

The successful doctor bought a piece of land near the Holyhead road, and built on it a large square house, of plain architecture, which from its charming position, a hundred feet above the Severn, received the name of 
"The Mount." I Having thus provided the nest, in I 796 he brought home his wife, Susannah Wedgwood, eldest daughter of the celebrated potter, to whom he was married at Marylebone Church on April r8th.

The character and education of Charles Darwin's mother is a matter of considerable interest, notwithstanding that her death when he was only eight years old cut short her opportunities of influencing him. She was born at Burslem in January, 1765 , and a year after her father describes her as a "fine, sprightly lass :" she became his best-beloved child. She was partly educated in London, under the eye of her father's partner, the accomplished Thomas Bentley, in whose heart she won as tender a place as in her father's. Later she continued her education at home with her brothers, under good tuition. Many visits were exchanged between the Darwins and the

I "The house is seen," says Mr. Woodall, "from the line immediately beyond the low tower of St. George's Church. Visitors who make a pilgrimage there, after crossing the Welsh Bridge, follow the main street until St. George's Church is passed, and the continuous line of houses ceascs. The ncxt carriage drive, on the right, cutting in two a lofty side-walk, is the entrance to The Mount. A short street of new houses, ncar St. Georgc's Church, has been called 'Darwin Street;' as yct the only public recognition in the town of the greatest of Salopians. A memorial of a more private character has been placed in the Unitarian Chapel, in the form of a tablet bearing the following inscription:- "To the memory of Charles Robert Darwin, author of "The Origin of Specics," born in Shrcivsbury, February r2th, I809. In early life a member and constant worshipper in this church. Died April I9th, I882.' Mrs. Darwin, we believe, was not strict in her adhesion to the communion in which she had been brought up, but often attended St. Chad's Church, where Charles and his brother were baptized." 
Wedgwoods, and old Erasmus Darwin became very fond of Miss Wedgwood. By the time of her marriage she was matured by much intercourse with notable people, as well as by extensive reading, and from her experience of London society and varied travel in England was well fitted to shine as the county doctor's wife. From her father, who died in I795, she had doubtless inherited, in addition to a handsome fortune, many valuable faculties, and probably she transmitted more of them to her son Charles than she herself manifested. Josiah Wedgwood, over whose career it would be delightful to linger, is well described by Miss Meteyard in words which might be precisely applied to Charles Darwin, as "patient, stedfast, humble, simple, unconscious of half his own greatness, and yet by this very simplicity, patience, and stedfastness displaying the high quality of his moral and intellectual characteristics, even whilst insuring that each step was in the right direction, and firmly planted." $\Lambda$ truly experimental genius in artistic manufacture, Wedgwood foreshadowed a far greater experimental genius in science.

Before her famous son was born, however, Mrs. Darwin's health had begun to fail, and in $\mathrm{x} 807$ she wrote to a friend: "Every one seems young but me." Her second son (four daughters having preceded him) was born at The Mount on February r 2, I 809, and christened "Charles Robert," at St. Chad's Church, Shrewsbury, on November 1 th following. No doubt her declining health emphasised her attachment to home pursuits, to quiet reading, to the luxuriant garden, and to her numerous domestic pets. The beauty, variety, and tameness of The Mount pigeons was well known in the town and far 
beyond. Mr. Woodall states that one of Darwin's schoolfellows, the Rev. W. A. Leighton, remembers him plucking a plant and recalling one of his mother's elementary lessons in botany. Too soon however the mother was taken from The Mount; she died in July, r8r 7 , when Charles was between eight and nine years old.

The eldest son of Dr. Robert Darwin, on whom the grandfather's name of Erasmus had been bestowed, is notable as the intimate friend of the Carlyles. "He had something of original and sarcastically ingenious in him," says Carlyle, in his "Reminiscences," "one of the sincerest, naturally truest, and most modest of men. . . . E. Darwin it was who named the late Whewell, seeing him sit, all ear (not all assent), at some of my lectures, "The Harmonious Blacksmith.' My dear one had a great favour for this honest Darwin always; many a road to shops, and the like, he drove her in his cab, in those early days when even the charge of omnibuses was a consideration, and his sparse utterances, sardonic often, were a great amusement to her. 'A perfect gentleman,' she at once discerned him to be, and of sound worth and kindliness, in the most unaffected form." He died in I8SI, aged 77, leaving no memorial to the public of his undloubtedly great abilities. Like his younger brother, he was a member of Christ's College, Cambridge, where he graduated M.B., in 1828 .

Early in 1817 , the closing year of his mother's life, Charles Darwin was placed at school with the Rev. George Case, minister of the Shrewsbury Unitarian church, to which the Darwins were attached, in this rescmbling ife Wedgwoods. At midsummer, i 8 i 8 , how- 
ever, the boy entered Shrewsbury Grammar School, then under Samuel Butler, afterwards Bishop of Lichfield. Classics, as ever, formed the staple of the instruction there afforded, and proved but little to the future naturalist's taste. Unfortunately for the repute of English schools, Charles Darwin was little benefited by his schooling; and Euclid, then an extra subject, constituted, to his mind, the only bit of real education Shrewsbury school gave him. Seventy years later, the study of mother earth and her tceming productions, which Darwin made so attractive, is still but scantily represented in the instruction afforded by our great schools.

Thus out of sympathy with the prevalent studies, the youth showed no fondness for his schoolfellows' sports. He was reserved, frequently lost in thought, and fond of long solitary rambles, according to one schoolfellow, the Rev. W. A. Leighton; another, the Rev. John Yardley, Vicar of St. Chad's, Shrewsbury, remembers him as cheerful, good-tempered, and communicative. One of the recorded incidents of his boyish days is a fall from the old Shrewsbury wall, while walking in a "brown study." Even at this early period he was fond of collecting objects which many schoolboys delight in, such as shells and minerals, seals, franks, and coins; and the mechanical aptitude derived from both the Darwins and the IVedgwoods was manifested by keen interest in mechanism. One especially remembered youthful treat was when his uncle Josiah Wedgwood explained to him the principle of the vernier. No doubt the pigeons, the exotics, the shrubs and flowers of his father's grounds impressed themselves indelibly on the boy's mind and 
unconsciously prepared him for his future. Schooldays were for him fortunately not protracted, for in 1825 , at the age of sixteen, he went to Edinburgh University, where his father and grandfather had likewise studied, with the idea of devoting himself to medicine. The youth of sixteen was well equipped with the results of long thinking and observing rather than with booklearning, and was prepared to play an independent part without noise and show, assimilating that which commended itself to his mind, and rejecting that which found no appropriate soil in him, in a manner characteristic of genuine originality. 


\section{CHAPTER II.}

T HEN Charles Darwin went to Edinburgh, the university was not in one of its palmiest periods. The medical professors failed to attract him to their profession, and two years of Edinburgh satisfied him that medicine should not absorb him. With natural history the case was different. Its attractiveness for Darwin increased. He found congenial companionship in the Edinburgh Plinian Society, and Mr. W. F. Ainsworth relates (in The Athenceum, May r3, I882) that Darwin and himself made frequent excursions on the shores of the Firth of Forth in pursuit of objects of natural history, sometimes visiting the coasts of Fifeshire, and sometimes the islands off the coast. On one occasion, accompanied by Dr. Greville, the botanist, they went to the Isle of May, and were both exceedingly amused at the effect produced upon the eminent author of the Scottish Cryptogamic Flora by the screeching of the kittiwakes and other water-fowl. He had actually to lie down on the greensward to enjoy his prolonged cachinnation. On another occasion the young naturalists were benighted on Inch Keith, but found refuge in the lighthouse.

Darwin was now not merely a collector and exploring 
naturalist, but he observed biological facts of importance. On the 27 th of March, 1827 , he nuade a communication to the Plinian Society on the ova, or rather larva, of the Flustra or sea-mat, a member of the class Polyzon, forming a continuous mat-like colony of thousands of organisms leading a joint-stock existence. He announced that he had discovered in these larvæ organs of locomotion, then so seldom, now so frequently, known to exist on such bodies. At the same time, he made known that the small black body which until that time had been mistaken for the young state of a species of seaweed, was in reality the egg of Pontobdella muricata, a sort of sea-leech. On the 3 rd of April following, the discoverer exhibited specimens of the latter creature with eggs and young.

In making these researches, Darwin was no doubt stimulated and aided by the teaching of Dr. Grant, afterwards Professor of Natural History at University College, London, who was then at Edinburgh, making discoveries in the structure of sponges. Professor Jameson, too, who was then forming his splendid museum of natural history, cannot fail to have influenced Darwin somewhat; and we find that the first lecture of the concluding portion of Jameson's zoological course, dealing with "The Philosophy of Zoology," had the suggestive title of "The Origin of the Species of Animals." Thus we must acknowledge that already at Edinburgh Darwin was fairly started in the paths of zoological inquiry, and the northern university must be admitted to share with Cambridge, the distinction of being the foster-parent of this giant-child. 
Medicine being distasteful, Edinburgh had no other distinctive charms to offer to young Darwin, and he was entered at Christ's College, Cambridge, early in $\mathrm{s} S 2 S$, with the idea of his becoming a clergyman of the Church of England. It might have been thought that there was scant stimulus for a biological student in the Cambridge of that period; but although the old literary and mathematical studies were still the only paths to a degree, there wcre men of original force and genius at work preparing the ground for a coming revolution. Sedgwick was teaching geology with the fire of a prophet, and Henslow as a botanist was showing that lessons of enthralling interest were to be learned from the humblest flower. Henslow especially attracted young Darwin, who never forgot his old teacher. In the preface to the journal of his voyage in the Beagle he returns his most sincere thanks to Professor Henslow, "who," he says, "when I was an undergraduate at Cambridge, was one chief means of giving me a taste for natural history; who, during my absence, took charge of the collections I sent home, and by his correspondence directed my endeavours-and who, since my return, has constantly rendered me every assistance which the kindest friend could offer."

No better idea of Darwin's Cambridge days can be given than that which is derived from reading his account of Professor Henslow, contributed to the Rev. L. Jenyns's "Memoirs" of that accomplished man. There can be no doubt, also, that in thus pourtraying the character of another, he was at the same time, as Mr. Romanes puts it, "unconsciously giving a most accurate description of his own." 
"I went to Cambridge," wrote Darwin, "early in the year 1828 , and soon became acquainted, through some of my brother entomologists, ${ }^{\mathrm{I}}$ with Professor Henslow, for all who cared for any branch of natural history were equally encouraged by him. Nothing could be more simple, cordial, and unpretending than the encouragement which he afforded to all young naturalists. I soon became intimate with him, for he had a remarkable power of making the young feel completely at ease with him; though we were all awe-struck with the amount of his knowledge. Before I saw him I heard one young man sum up his attainments by simply saying that he knew everything. When I reflect how immediately we felt at perfect ease with a man older and in every way so immensely our superior, I think it was as much owing to the transparent sincerity of his character, as to his kindness of heart, and,

I This statement by Darwin disposes of Mr. Grant Allen's assertion that geology was Darwin's "first love" (p. 36). IIe reckoned himself an entomologist when he went to Cambridge, and certainly Mr. Ainsworth's statement shows that he was a naturalist in a wide sense while at Edinburgh. C. V. Riley, the well-known American entomologist, says (Procecdings of the Biological Society of Washington, U.S., vol. i., I882, p. 70) "I have the authority of my late associate editor of The American Entomolo. gist, Benjamin Dann Walsh, who was a class-mate of Darwin's at Cambridge, that the latter's love of natural history was chiefly manifested, while there, in a fine collection of insects." Indeed, he was one of the original members of the Entomological Society of London, founded in $\mathrm{I} \delta 33$, and showed an active interest in its affairs throughout life, being elected a member of its council in 1838 . As early as January 4, I836, a memoir based on insects sent home by Darwin from Chiloe, was read before the Society by Charles Babington, now Professor of Botany at Cambridge. 
perhaps, even still more to a highly remarkable absence in him of all self-consciousness. One perceived at once that he never thought of his own varied knowledge or clear intellect, but solely on the subject in hand. Another charm, which must have struck every one, was that his manner to old and distinguished persons and to the youngest student was exactly the same: to all he showed the most winning courtesy. He would receive with interest the miost trifling observation in any branch of natural history, and however absurd a blunder one might make, he pointed it out so clearly and kindly, that one left him in no way disheartened, but only determined to be more accurate the next time. In short, no man could be better formed to win the entire confidence of the young, and to encourage them in their pursuits.

"His lectures on botany were universally popular, and as clear as daylight. So popular were they, that several of the older nembers of the university attended successive courses. Once every week he kept open house in the evening, and all who cared for natural history attended these parties, which, by thus favouring intercommunication, did the same good in Cambridge, in a very pleasant manner, as the scientific societies do in London. At these parties many of the most distinguished members of the university occasionally attended; and when only a few were present, I have listened to the great men of those days conversing on all sorts of subjects, with the most varied and brilliant powers. This was no small advantage to some of the younger men, as it stimulated their mental activity and ambition. 'Two or three times in each session he took excursions with 
his botanical class, either a long walk to the habitat of some rare plant, or in a barge down the river to the fens, or in coaches to some more distant place, as to Gamlingay, to see the wild lily-of-the-valley, and to catch on the heath the rare natter-jack. These excursions have left a delightful impression on my mind. He was, on such occasions, in as good spirits as a boy, and laughed as heartily as a boy at the misadventures of those who chased the splendid swallow-tail butterflies across the broken and treacherous fens. He used to pause every now and then and lecture on some plant or other object; and something he could tell us on every insect, shell, or fossil collected, for he had attended to every branch of natural history. After our day's work we used to dine at some inn or house, and most jovial we then were. I believe all who joined these excursions will agree with me that they have left an enduring impression of delight on our minds.

"As time passed on at Cambridge I became very intimate with Professor Henslow, and his kindness was unbounded; he continually asked me to his house, and allowed me to accompany him in his walks. IIe talked on all subjects, including his deep sense of religion, and was entirely open. I owe more than I can express to this excellent man. His kindness was steady. When Captain Fitzroy offered to give up part of his own calsin to any naturalist who would join the expedition in H.M.S. Beagle, Professor Henslow recommended me as one who knew very little, but who, he thought, would work. I was strongly attached to natural history, and this attachment $I$ owed in large part to him. During the 
five years' voyage he regularly corresponded with me, and guided my efforts; he received, opened, and took care of all the specimens sent home in many large boxes; but I firmly believe that, during these five years, it never once crossed his mind that he was acting towards me with unusual and generous kindness.

"During the years when I associated so much with Professor Henslow I never once saw his temper even ruffled. He never took an ill-natured view of any one's character, though very far from blind to the foibles of others. It always struck me that his mind could not be even touched by any paltry feeling of vanity, envy, or jealousy. With all this equability of temper and remarkable benevolence, there was no insipidity of character. A man must have been blind not to have perceived that beneath this placid exterior there was a vigorous and determined will. When principle came into play no power on earth could have turned him one hair's breadth. . . .

"In intellect, as far as I could judge, accurate powers of observation, sound sense, and cautious judgment seemed predominant. Nothing seemed to give him so much enjoyment as drawing conclusions from minute observations. But his admirable memoir on the geology of Anglesea shows his capacity for extended observations and broad views. Reflecting over his character with gratitude and reverence, his moral attributes rise, as they should do in the highest character, in pre-eminence over his intellect."

The young man's modesty is conspicuous in the above narrative. He does not see how his own transparent 
candour, his desire to learn, his respect for those who were already masters of science, won upon the great men with whom he came in contact. It was by no means as "one who knew very little" that Henslow recommended Darwin to Captain Fitzroy, but as "a young man of promising ability, extremely fond of geology, and indeed all branches of natural history." "In consequence," says Fitzroy, "an offer was made to Mr. Darwin to be my guest on board, which he accepted conditionally. Permission was obtained for his cmbarkation, and an order given by the Admiralty that he should be borne on the ship's books for provisions. The conditions asked by Mr. Darwin were, that he should be at liberty to lave the Beagle and retire from the expedition when he thought proper, and that he should pay a fair share of the expenses of my table."

Darwin had taken an ordinary or "poll" degree in I $83 \mathrm{I}$, and was admitted a Master of Arts in 1837 . In the interval he had become truly a Master of Science, which at that time was adequately recognised by no university in the British dominions. The memorable voyage of the Beagle, a little barque of 242 tons, was at first delayed by heavy gales which twice drove her back; but she finally sailed from Devonport on December $27, \mathrm{r} S_{3} \mathrm{I}$. The object of the expedition was to complete the survey of Patagonia and Tierra del Fuego, to survey the shores of Chili, Peru, and some Pacific Islands, and to carry a chain of chronometrical measurements round the world.

Professor Henslow's interest in his young pupil's progress is shown by the fact that in $\mathrm{r} 83.5$ (December I) 
he printed some extracts from his letters, for distribution among the members of the Cambridge Philosophical Society, in consequence of the notice excited by some geological observations they contained, which had been read before the society on the $\mathrm{r}$ Gth of November previous. The following points having a personal reference to the traveller may be quoted. On August I5, I 832 , Darwin wrote from Monte Video, "I might collect a far greater number of specimens of invertebrate animals if I took up less time over each : but I have come to the conclusion that two animals with their original colour and shape noted down will be more valuable to naturalists than six with only dates and place." Here we see the accuracy which was the source of much of his aftersuccess. On November 24,1832 , he writes from the same place, "As for one little toad, I hope it may be new, that it may be christened 'Diabolicus.' Milton must allude to this very individual, when he talks of 'squat like a toad.' " In March, I834, writing from East Falkland Island, he says, "The whole of the east coast of the southern part of South America has been elevated from the ocean since a period during which mussels have not lost their blue colour.' Describing his examination of the central peaks of the Andes in Chili, he says, April I8, I835, "I cannot tell you how much I enjoyed some of these views; it is worth coming from England, once to feel such intense delight. At an elevation of from ten to twelve thousand feet, there is a transparency in the air, and a confusion of distances, and a sort of stillness, which give the sensation of being in another world." 
Coming now to Darwin's Journal as first published in I839, forming the third volume of Fitzroy's narrative, the 7 th of January, 1832 , on which the Peak of Teneriffe was seen suddenly illumined, while the lower parts were veiled in fleecy clouds, is noted as "the first of many delightful days never to be forgotten." On the I 6 th the Cape de Verde Islands were reached, and their volcanic geology was carefully explored. Darwin was already equipped with the first volume of Lyell's famous "Principles of Geology," published in 1830 , the second following in 1832 ; and in the second edition of his journal, published in 1845 , he acknowledges with grateful pleasure "that the chief part of whatever scientific merit this journal and the other works of the author may possess, has been derived from studying the well-known and admirable 'Principles of Geology.' " He was already noting the diffusion of minute organisms and impalpable dust by winds, ${ }^{\mathrm{I}}$ and was much surprised to find in some dust collected on a vessel 300 miles from land particles of stone more than a thousandth of an inch square. After this, he remarks, one need not be surprised at the diffusion of the far lighter and smaller sporules of cryptogamous plants.

The volcanic island of St. Paul in the open Atlantic was touched at on February I6th, and it afforded the young naturalist a text for destroying the pretty ideas

${ }^{x}$ Mr. Grant Allen ("Darwin," p. 42) states that Darwin observed sixty-seven distinct organic forms in the fine dust which fell on deck. It was Ehrenberg who determined these organisms in dust sent tc him by Darwin, and four out of five of the packets of dust sent to Ehrenberg were given to Darwin by Lyell (Darwin's Journal, second edition, p. 5). 
as to stately palms and birds taking possession of newlyformed oceanic land; at any rate, here were only two species of sea birds, no plants, and the fauna was completed by a number of insects and spiders of no very exalted habits. Fernando Noronha was passed on February 2oth, and at last the South American continent was reached.

On February 29 th, at Bahia, Darwin describes his first day in a Brazilian forest, in a passage which is of special interest. "The day has passed delightfully. Delight itself, however, is a weak term to express the feelings of a naturalist who, for the first time, has wandered by himself in a Brazilian forest. 'The elegance of the grasses, the novelty of the parasitical plants, the beauty of the flowers, the glossy green of the foliage, but, above all, the general luxuriance of the vegetation, filled me with admiration. A most paradoxical mixture of sound and silence pervades the shady parts of the wood. The noise from the insects is so loud that it may be heard even in a vessel anchored several hundred yards from the shore; yet within the recesses of the forest a universal silence appears to reign. To a person fond of natural history, such a day as this brings with it a deeper pleasure than he can ever hope to experience again."

Arriving at Rio de Janeiro early in April, Darwin made several excursions into the interior during the following three months. On these expeditions it was rarely indeed that decent accommodation could be procured at the inns. "On first arriving," he says, "it was our custom to unsaddle the horses and give them their Indian corn; then, with a low bow, to ask the senhor to do us the 
favour to give us something to eat. "Anything you choose, sir,' was his usual answer. For the few first times, vainly I thanked Providence for having guided us to so good a man. The conversation proceeding, the case universally became deplorable. 'Any fish can you do us the favour of giving?' 'Oh, no, sir!' 'Any soup?' 'No, sir!' 'Any bread?' 'Oh, no, sir!' 'Any dried meat?' 'Oh, no, sir!' If we were lucky, by waiting a couple of hours, we obtained fowls, rice, and farinha. It not unfrequently happened that we were obliged to kill, with stones, the poultry for our own supper. When, thoroughly exhausted by fatigue and hunger, we timorously hinted that we should be glad of our meal, the pompous and (though true) most unsatisfactory answer was, 'It will be ready when it is ready!' If we had dared to remonstrate any further, we should have been told to proceed on our journey, as being too impertinent. The hosts are most ungracious and disagreeable in their manners; their houses and their persons are often filthily dirty; the want of the accommodation of forks, knives, and spoons is common; and I am sure no cottage or hovel in England could be found in a state so utterly destitute of every comfort."

When we add to these discomforts on land the fact that the young traveller was a constant sufferer from sea-sickness and nausea, which became chronic, it becomes more surprising that he should not have withdrawn early from his adventurous course. But his energy and resolution were equal to any drafts upon them, and the delights of the study of nature outweighed all physical discomforts, Admiral J. I,ort Stokes in a letter 
to The Times, after the death of his old friend and comrade in the Bcagle, described how after perhaps an hour's work he would say, "Old fellow, I must take the horizontal for it." 'Then he would stretch himself on one side of the table, and obtain a brief relief from discomfort, aftcr which he would resume work.

Some remarks which Darwin makes upon slavery in South America are very forcible, and also illustrate his own sympathetic nature. Here is one incident which struck him more than any story of cruelty, as showing the degradation of slavery. "I was crossing a ferry with a negro, who was uncommonly stupid. In endeavouring to make him understand, I talked loud, and made signs, in doing which I passed my hand near his face. He, I suppose, thought I was in a passion, and was going to strike him ; for instantly, with a frightened look and halfshut eyes, he dropped his hands. I shall never forget my feelings of surprise, disgust, and shame, at seeing a great powerful man afraid even to ward off a blow, directed, as he thought, at his face. This man had been trained to a degradation lower than the slavery of the most helpless animal."

In one of the numerous additions to the second issue of the Journal in $\mathrm{x} 845$, Darwin speaks thus eloquently from his heart: "On the Igth of August $\left[{ }^{8} 8_{3} 6\right.$ ], we finally left the shores of Brazil. I thank God I shall never again visit a slave-country. To this day, if I hear a distant scream, it recalls with painful vividness my feelings when, passing a house near Pernambuco, I heard the most pitiable moans, and could not but suspect that some poor slave was being tortured, yet knew that I 
was as powerless as a child, even to remonstrate. I suspected that these moans were from a tortured slave, for I was told that this was the case in another instance. Near Rio de Janeiro I lived opposite to an old lady, who kept screws to crush the fingers of her female slaves. I have stayed in a house where a young household mulatto, daily and hourly, was reviled, beaten, and persecuted enough to break the spirit of the lowest animal. I have seen a little boy, six or seven years old, struck thrice with a horse-whip (before I could interfere) on his naked head, for having handed me a glass of water not quite clean; I saw his father tremble at a mere glance from his master's eye. ... I will not even allude to the many heartsickening atrocities which I authentically heard of ; nor would I have mentioned the above revolting details, had I not met with several people, so blinded by the constitutional gaiety of the negro, as to speak of slavery as a tolerable evil. . . . Those who look tenderly at the slaveowner, and with a cold heart at the slave, never seem to put themselves into the position of the latter. What a cheerless prospect, with not even a hope of change! Picture to yourself the chance, ever hanging over you, of your wife and your little children - those objects which nature urges even the slave to call his own-being torn from you, and sold like beasts to the first bidder! And these deeds are done and palliated by men who profess to love their neighbours as themselves, who believe in God, and pray that His will be done on earth!"

Such burning expressions are not yet superfluous, and it is wholesome to recall to a generation which scarcely realises the past miscries of slavery, and is too apt to 
rest content with what has been accomplished in diminishing the sufferings of slaves, white and black, the impression produced on a scientific man by what he saw. It is well, too, that it should be brought forcibly home to Englishmen that Darwin's heart was no less sympathetic than his intelligence was far-seeing, and that the testimony of friends of late years to his moral grandeur is corroborated by the personal records of his years of travel.

The variety and interest of the observations made during his stay at Rio, when tropical nature was still a fresh and unexplored page to the young observer, are wonderful. Cabbage palms, liana creepers, luxuriant fern leaves-roads, bridges, and soil-planarian worms, frogs which climbed perpendicular sheets of glass, the light of fireflies, brilliant butterflies, fights between spiders and wasps, the victories of ants over difficulties, the habits of monkeys, the little Brazilian boys practising knife-throwing-all these came in turn under his watchful eyes and are vividly described.

In July, I 832 , Monte Video was reached, and the Beagle.was occupied in surveying the extreme southern and eastern coasts of America, south of La Plata, during the succeeding two years. During ten weeks at Maldonado an entertaining excursion to the River Polanco was made, and many a humorous remark appears in the Journal relating to it. "The greater number of the inlabitants [of European descent] had an indistinct idea that England, London, and North America were different names for the same place; but the better-informed well knew that London and North America were separate countries close together, and that 
England was a large town in London!" "Washing my face in the morning caused much speculation at the village of Las Minas; a superior tradesman closely cross-questioned me about so singular a practice." Among these rich descendants of Europeans Darwin felt as if he were among the inhabitants of Central Africa; so low can the proud superior race descend, that the distance between it and the negro appeared small indeed. The remarkable absence of trees in the country could not fail to provoke comment; but it is on the oldfashioned basis, and the young student does not get beyond the conclusion "that herbaceous plants, instead of trees, were created to occupy that wide area, which, within a period not very remote, has been raised above the waters of the sea." This appears in the first edition; but in $\mathrm{I}_{45}$ these words were expunged, and the author says significantly "we must look to some other and unknown cause."

At Maldonado within the distance of a morning's walk no fewer than eighty species of birds were collected, most of them exceedingly bcautiful. Darwin's observations on the molothri (representatives of our cuckoos), the tyrant fly-catchers, and the carrion-feeding hawks are most attractive reading. Rio Negro, much further south, was next visited, and the fauna of a salt lake examined. The adaptation of creatures to live in and near brine struck him as wonderful. "Well may we affirm," says he, "that every part of the world is habitable! Whether lakes of brine, or those subterranean ones, hidden beneath volcanic mountains-warm mineral springs - the wide expanse and depths of the ocean-the 
upper regions of the atmosphere, and even the surface of perpetual snow-all support organic beings." Here he found reason to believe that all the great plains which he was surveying had been raised above the sea level in a modern geological period.

Our naturalist started by land for Bahia Blanca and Buenos Ayres on August II, I833, and we have the record: "This was the first night which I had ever passed under the open sky, with the gear of the recado for my bed. There is high enjoyment in the independence of the Gaucho's life, to be able at any moment to pull up your horse, and say, 'Here we will pass the night.' The deathlike stillness of the plain, the dogs keeping watch, the gipsy group of Gauchos making their beds round the fire, have left in my mind a strongly-marked picture of this first night, which will not soon be forgotten." After an interesting rencontre with General Rosas, Bahia Blanca was reached, and at Punta Alta were found many of the fossil bones which Owen subsequently described, this point being a perfect catacomb, as Darwin terms it, for monsters of extinct races. The remains of nine great kinds of quadrupeds chiefly allied to the sloths were found embedded on the beach within a space of about two hundred yards square; and these were associated with shells of molluscs of still existing species. Here was indeed a remarkable fact to germinate in the great naturalist's mind. It bore full fruit at a later date. An important theory then current, that large animals require a luxuriant vegetation, was overthrown at the same time, for there was every reason to believe that the sterility of the surrounding country was no new thing. 'The South 
American ostrich and many other animals here afforded material for important observations.

On the way to Buenos Ayres, the rugged Sierra de la Ventana, a white quartz mountain, was ascended. Buenos Ayres was reached on September 20, 1833, and no time was lost in arranging for an expedition to Santa Fé, nearly 300 miles up the Parana. On October 3, Santa Fé was entered, and near it many more remains of large extinct mammals were found. The remains of a horse, in a similar fossil condition, greatly astonished our explorer, for it seemed indeed surprising that in South America a native horse should have co-existed with giant extinct forms, and should itself have become extinct, to be succeeded in modern times by the countless herds descended from the few horses introduced by the Spanish colonists. These and other strange facts in the distribution of mammalian animals in America led Darwin to make some pregnant comments. The enormous number of large bones embedded in the estuary deposits became continually more evident, until he came to the conclusion that the whole area of the Pampas was one wide sepulchre.

Unfortunately ill-health compelled the explorer to return, and on October I 2 th he started for Buenos Ayres in a small vessel. During this journey he had an opportunity of examining the shifting and variable islands of the muddy Parana, on which the jaguar thrives. Arrived at Las Conchas, a revolution had broken out, and Darwin was detained to a certain extent under surveillance; but by the infuence of General Rosas' name, he was allowed to pass the 
sentinels, leaving his guide and horses behind, and ultimately reached Buenos Ayres in safety. After a fortnight's delay, Monte Video was once more made for. Here it appeared that the Beagle would remain sometime longer, so the restless inquirer started on another expedition, this time up the Uruguay and Rio Negro. One of the halts was at the house of a very large landed proprietor. A friend of the proprietor's, a runaway captain from Buenos Ayres, was very anxious to have the traveller's opinion on the beauty of the Buenos Ayres ladies, and on receiving satisfactory assurances, voluntarily gave up his bed to the stranger! During this journey amazing quantities of huge thistles were met with, the cardoon being as high as a horse's back, while the Pampas thistle rose above the rider's head. To leave the road for a yard was out of the question. Incidentally the writer describes fully the horsemanship of the Gauchos, and gives a vivid picture of the state of socicty in the towns.

During this journey, too, a peculiar breed of small cattle, called niata, was observed, but full details were not given till the second edition of the Journal appeared. This breed is strangely at a disadvantage in droughts, compared with ordinary cattle; their lower jaws project beyond the upper, and their lips do not join, rendering them unable to browse on twigs. "This strikes me," says Darwin, "as a good illustration of how little we are able to judge from the ordinary habits of life, on what circumstances, occurring only at long intervals, the rarity or extinction of a species may be determined." By the time this appeared, however, in $\mathbf{1} 845$, the author had embarked on his great investigation. 
The Rio Plata was quitted on December 6, I833, and sail was made for Port Desire, on the coast of Patagonia. One evening, ten miles from the Bay of San Blas, myriads of butterflies filled the air, so that the seamen cried out that it was snowing butterflies. The flight seemed to be voluntary. On another occasion many beetles were found alive and swimming, seventeen miles from the nearest land. But these instances were insignificant compared with the alighting of a large grasshopper on the Beagle, when to windward of the Cape de Verde Islands, and when the nearest land, in a direction not opposed to the prevailing trade wind, was 370 miles distant. Marvellous appearances of spiders far from land were also noted. One day when the ship was sixty miles from land vast numbers of a small gossamer spider arrived. Its habits in fact were aëronautic; it would send forth a small thread, and suddenly letting go its hold, would sail away horizontally.

The Beagle arrived at Port Desire on December 23, 1833 , but Patagonia afforded less of interest to the zoologist than the northern countries. The next halt was made at Port St. Julian, I I o miles further south, on January 9, I 834 . Here the evidences of the modern elevation of Iatagonia were powerfully reinforced, and further, from the nature of the animal remains arose the conviction that "existing animals have a close relation in form with extinct species," another of the germinal facts which bore fruit in the "Origin of Species." Darwin was led to speculate on the causes which could have extinguished so many great species, and he remarks most suggestively: "One is tempted to believe in such simple 
relations as variation of climate and food, or introduction of enemies, or the increased numbers of other species, as the cause of the succession of races." But he does not yet go farther. He ends his reflections by observing: "All that at present can be said with certainty is that, as with the individual, so with the species, the hour of life has run its course, and is spent."

In the second edition of the Journal the philosopher showed signs of considerable advance (pp. I 74-5). The effect of changed conditions is further developed. The checks to indefinite multiplication are insisted on, while the tendency of every species to increase geometrically is clearly pointed out. In the place of the former concluding sentence we find the following: "To admit that species generally become rare before they become extinct-to feel no surprise at the comparative rarity of one species with another, and yet to call in some extraordinary agent and to marvel greatly when a species ceases to exist, appears to me much the same as to admit that sickness in the individual is the prelude to deathto feel no surprise at sickness-but when the sick man dies, to wonder, and to believe that he died through violence."

The continental regions of South America did not supply the sole food for the reflections of the young naturalist during this period. An intervening visit had been paid, in December, $1 \delta_{32}$, and January, $\mathbf{8} 33$, to Tierra del Fuego, and the natives were most carefully observed. He was greatly struck by their low condition; " one can hardly make oneself believe they are fellow creatures, and inhabitants of the same world." Yet 
these abject people have been infinitely raised since that period by missionaries, and Darwin, hearing of this success, which he termed wonderful, sent a donation to the South American Missionary Society.

The Falkland Islands were explored both in $\mathrm{I} 833$ and 1834 , and the Straits of Magellan were carefully examined, and many valuable geological facts recorded. The southern portion of the continent was at last quitted for Chili, Valparaiso being reached on July 23, I 834. After Tierra del Fuego this was a delightful change, and here Darwin found an old schoolfellow and friend, Mr. Richard Corfield, who entertained him hospitably during his stay in Chili. Various expeditions to the Andes, to Santiago, to gold mines and copper mines, supplied abundant objects of curiosity and science, as well as varied visions of beauty; but the fatigues undergone had to be paid for by a month's illness at Valparaiso, during which Mr. Corfield's kindness was unremitting.

The large island of Chiloe was visited in November, and its climate even in summer proved wretched, reminding one of some parts of the Hebrides, a week without torrents of rain being wonderful. Castro, the almost deserted Spanish capital, could not furnish, cren among hundreds of inhabitants, a pound of sugar or an ordinary knife. No one possessed either a watch or a clock, and the church bell was rung by guess by an old man who was supposed to have the best notion of time.

In December the rugged Chonos Archipelago, still further south, was explored. Here a storm worthy of 'lierra del Fuego was experienced. "White, massive 
clouds were pilcd up against a dark blue sky, and across them black, ragged sheets of vapour were rapidly driven. The successive mountain ranges appeared like dim shadows; and the setting sun cast on the woodland a yellow gleam, much like that produced by the flame of spirits of wine on a man's countenance. The water was white with the flying spray; and the wind lulled and roared again through the rigging. It was a most ominous, sublime scene." While near Tres Montes the ycar 1835 was ushered in, as Darwin says, "with the ceremonies proper to it in these regions. She lays out no false hopes; a heavy N.W. gale, with steady rain, bespeaks the rising year. Thank God, we are not destined here to see the end of it, but hope then to be in the Pacific, where a blue sky tells one there is a heavena something beyond the sky above our heads."

Valdivia being reached in February, the Beagle party were witnesses of a severe earthquake. Darwin was on shore, lying down in the wood to rest. The effect produced upon him by the motion he experienced was very marked: "There was no difficulty in standing upright, but the motion made me almost giddy. It was something like the movement of a vessel in a little cross ripple, or still more like that felt by a person skating over thin ice, which bends under the weight of his body. $A$ bad earthquake at once destroys the oldest associations; the world, the very emblem of all that is solid, has moved beneath our feet like a crust over a fluid; one second of time has conveyed to the mind a strange idea of insecurity, which hours of reflection would never have created." By the same earthquake every house in 
Concepcion (afterwards visited) was thrown down, and a most impressive sight met the travellers.

Arriving at Valparaiso again on March I I, I 835, after only an interval of two days the indefatigable explorer started to cross the Cordillera by the seldom traversed Portillo pass. Here geological observations were abundant. The roar of the mountain torrents spoke eloquently to the geologist. "The thousands and thousands of stones, which, striking against each other, make the one dull uniform sound, are all hurrying in one direction. It is like thinking of time, when the minute that now glides past is irrecoverable. So it is with these stones; the ocean is their eternity, and each note of that wild music tells of one other step towards their destiny." Who can fail to discern in such a passage the poetic instinct which Erasmus Darwin more fully manifested?

Mendoza was reached on March 27 th, and on the 29 th the return journey by the northern or Uspallata pass was commenced. On the roth of April Santiago was again arrived at, and Mr. Caldcleugh most hospitably welcomed the traveller, delighted with his expedition. "Never," he says, "did I more deeply enjoy an equal space of time." Various excursions in Northern Chili and Peru followed. Little was seen of Peru, owing to the troubled state of public affairs, and there was very little regret when the Bergle started early in September on her journey across the Pacific.

The Galapagos Islands, with their two thousand volcanic craters, their apparently leafless bushes and wretched weeds, their peculiar animals, so unsuspicious of man that they did not move when stones were thrown, 
were extremely interesting to the naturalist, and gave rise to numerous observations and suggestions in later works. The huge tortoises slowly carrying their great boclies about, appeared like strange antediluvian animals. The hideous large water-lizard (Amblyrhynchus), swimming with perfect ease, and capable of an hour's immersion in sea-water; and the land lizard of the same genus, so numerous that at James Island it was hardly possible to find a spot free from their burrows, the roofs of which constantly give way under the pedestrian, were equally strange denizens of this group of islands, where reptiles replace herbivorous mammals. With regard to the last-mentioned species we find a remark indicating the persistence of a belief in special creation up to this date. "It would appear as if this species had been created in the centre of the Archipelago, and thence had been dispersed only to a certain distance."

During the years intervening between the first and second editions of the Journal, reflection intensified Darwin's perception of the singularity of the Galapagos fauna. "Considering the small size of these islands," he says, "we feel the more astonished at the number of their aboriginal beings, and at their confined range. Seeing every height crowned with its crater, and the boundaries of most of the lava streams still distinct, we are led to believe that within a period geologically recent the unbroken sea was here spread out. Hence, both in space and time, we seem to be brought somewhat nearer to that great fact-that mystery of mysteries-the first appearance of now beings on this earth." And he afterwards says, "One ịs astonished at the amount of creative 
force, if such an expression may be used, displayed on these small, barren, and rocky islands; and still more so at its diverse yet analogous action in points so near each other."

The long voyage to Tahiti, 3,200 miles, begun on October 20 , 1835 , ending on November i 5 th, was succeeded by a most enjoyable stay. Darwin was as delighted as any traveller with the charms of the island and the islanders. His testimony to the quality of English products is worth noticing, if only as a piece of natural patriotism. He acknowledges that Tahitian pineapples are of excellent flavour, perhaps better than those cultivated in England, and this he believes to be the highest compliment which can be paid to a fruit, or indeed to anything else. He found reason to speak well of the influence of the Christian missionaries on the natives, and of the conscientiousness of the latter, in opposition to Kotzebue's narrative.

On December I $9^{\text {th }}$ New Zealand was sighted. Our traveller's observations here are of much value, as relating to a late period before civilised government was effectively established. At Waimate he was delighted with the effects produced by the religious teacher. "The lesson of the missionary is the enchanter's wand," and he rejoiced as an Englishman at what his countrymen had effected. The remarkable absence of land mammals, the late enormous increase of the imported Norway rat, the dock spreading far and wide, its seeds having been sold as tobacco seeds by a rascally Englishman, the huge Kauri pines, were all full of import to the inquiring mind; but New Zealand proved on the whole less 
attractive, as seen by Darwin, than most other countries he had visited. December 3 oth saw the Beagle on the way to Sydney, and Port Jackson was reached on January I 2, $\delta_{3} 6$. An interesting excursion to the Blue Mountains and to Bathurst showed many aspects of colonial life, as well as the strange duckbill or platypus in its native haunts. Tasmania, with which island Darwin was greatly pleased, was visited in February. In April the Keeling Islands furnished much of the material for the future bock on coral reefs, the essence of which is, however, included in the Journal. Mauritius, Cape Town, St. Helena, Ascension, Bahia, Pernambuco, Cape Verde, and the Azores were the successive stages of the homeward journey, and on October 2, I836, anchor was cast at Falmouth, where the naturalist, equipped for his life work, was landed.

The high opinion Captain Fitzroy formed of Darwin during this long voyage is shown by many passages in his own narrative, and by many other references. He paid him the marked compliment of naming no fewer than three important geographical localities after him, namely, Mount Darwin and Darwin Sound (Tierra del Fuego), and Port Darwin in North Australia, thus connecting his name for future generations with two lands whose inhabitants were subjects of Darwin's unceasing interest and investigation throughout life, and served in no small degree to elucidate the history and rise of mankind in Darwin's mind and for a world's instruction. Fitzroy complimented his friend markedly when himself receiving the medal of the Royal Geographical Society; and in one of his papers, speaking of him as a zealous 
volunteer in the cause of science, observed that his perseverance might be estimated from the fact that he never ceased to be a martyr to sea-sickness; while his interest in science and his public spirit were evident from his having presented his valuable collections to the public.

The concluding pages of the Journal are both eloquent and instructive. Everywhere there had been fascinating visions, and attractive problems remained unsolved. Was it not significant of future studies that the contrast between barbarian and civilised man should have been so impressed upon the future author of "The Descent of Man"? He writes thus on this subject, "Of individual objects, perhaps no one is more certain to create astonishment than the first sight in his native haunt of a real barbarian, of man in his lowest and most savage state. One's mind hurries back over past centuries, and then asks, could our progenitors have been such as these? Men, whose very signs and expressions are less intelligible to us than those of the domesticated animals; men, who do not possess the instinct of those animals, nor yet appear to boast of human reason, or at least of arts consequent on that reason. I do not believe it is possible to describe or paint the difference between savage and civilised man. It is the difference between a wild and tame animal : and part of the interest in beholding a savage, is the same which would lead every one to desire to see the lion in his desert, the tiger tearing his prey in the jungle, the rhinoceros on the wide plain, or the hippopotamus wallowing in the mud of some African river."

We have dwelt thus at length upon the history of this 
eventful voyage, not only because it filled an important space in Darwin's life, but also because it undoubtedly gave rise to the thoughts and speculations which impelled him to devote his life to the study of problems of evolution. It has been shown to some extent, how he saw, without pre-arrangement, just those phenomena which could stimulate his mind, already fit, to its highest flights. We have seen, too, how universal was Darwin's interest in nature, and how sympatheic a heart went with his scientific insight. He had yet to show how masterly was his patience, to work for yet twenty years, in order that he might not by premature publication of a crude theory risk defeat and throw science backward rather than forward. This long patient work was to be the triumph of his genius. 


\section{CHAPTER III.}

$\mathrm{N}$ his return home, Darwin speedily placed himself in communication with the leaders of scientific progress, and, in consequence of the valuable results of his voyage, he soon found himself in a most advantageous position. On November 20 , I836, he was elected a Fellow of the Geological Society, and before the end of the year he had sent the manuscript of one of his early papers to Lyell, who writes to him (December 26, $\left.183^{6}\right)$ : "I have read your paper with the greatest pleasure. . . What a splendid field you have to write upon." He strongly advised the young man not to accept any official scientific place, but to devote himself to his own line of work. But Darwin was overpersuaded, and became a member of the Council of the Geological Society in the following February, and secretary in February, I 838 . This office he held with success for three years. Lyell referred in considerable detail to the young traveller's views in his presidential address to the Socicty in 1837 .

Darwin's geological papers soon became numerous. In 1837 he discussed in succession the recent elevation 
of the coast of Chili, the deposits containing extinct mammalia in the neighbourhood of the Plata, the areas of elevation and subsidence in the Pacific and Indian Oceans, as deduced from the study of coral formations, and the formation of mould (the precursor of a work he issued more than forty years later). Papers on the connection of certain volcanic phenomena, and on the formation of mountain chains, and other geological notes on South America, were read in $\mathrm{I}_{3} 8$; the interesting Parallel Roads of Glen Roy, in Scotland, which he believed to be of marine origin, were described in 1839 ; the erratic (glacial) boulders of South America, in $184 \mathrm{I}$; and coral reefs in 1842 : a full record, one would imagine, of busy years, occupied also with secretarial work. Lyell, writing to Sir John Herschel (May 24, r837), says: "I am very full of Darwin's new theory of coral islands, and have urged Whewell to make him read it at our next meeting. I must give up my volcanic crater theory for ever, though it costs me a pang at first." In March, 1838, Lyell describes the reception of the paper on volcanic phenomena at the Geological Society. "He opened upon De la Beche, Phillips, and others, his whole battery of the earthquakes and volcanoes of the Andes; and argued that spaces of a thousand miles long were simultaneously subject to earthquakes and volcanic eruptions, and that the elevation of the Pampas, Patagonia, \&c., all depended upon a common cause." In fit acknowledgment of such services to science, he was elected a Fellow of the Royal Society on January 24, I839.

Early in I839 Darwin married his cousin, Emma 
Wedgwood, daughter of his uncle Josiah Wedgwood: a union which, though consanguineous, proved in the highest degree congenial and fortunate. In succeeding years a numerous family of sons and daughters surrounded the happy parents. After considerable delays by the Admiralty, though it had long been ready, the Journal appeared, in 1839 , as the third volume of Fitzroy's "Voyages of The Adventure and Beagle." The Quarterly Reviezs (lxv. 224) said that there could be no two opinions of its merits. "We find ample materials for deep thinking; we have the vivid description that fills the mind's cyc with brighter pictures than painter can present, and the charm arising from the freshness of heart which is thrown over these virgin pages of a strong intellectual man, and an acute and deep observer." Its merits, however, were somewhat slow to become known to the general public, owing to the original expensive form of publication; and it was not till I 845 , when the second and enlarged edition appeared as "The Journal of Researches," that the popular ear was gained. Later, under the title, "A Naturalist's Voyage Round the World," the book has become very widely known and appreciated.

The publication of "The Zoology of the Voyage of The Beagle," commenced in 1838 , under Darwin's superintendence, gave a fuller view of the acquisitions to natural history which had been made than had previously been possible. The Treasury, acting on the representations of the presidents of the Linnean, Zoological, and Geological Societies, as well as of the naturalist himself, in 1837 made a grant of $\mathcal{E} 1000$ towards the expenses of publication of these memoirs. Owen's description of the 
fossil mammalia, completed in I 840 ; G. Waterhouse's of the living mammalia, in I 839 ; Gould's of the birds, in $\mathrm{I} S_{4} \mathrm{I}$; L. Jenyns's of the fish, in I $\delta_{42}$; and Thomas Bell's of the reptiles, in $\mathrm{s} 43$ - all in quarto, with beautiful plates, were a solid testimony to a splendid success. Darwin furnished an introduction to each part, and the portions of the text referring to the habits and ranges of the living animals. Three species of mastodon and the gigantic megatherium were the only extinct mammalia known from South America previous to Darwin's voyage. To these were now added the Mylodon Damuinii, a giant slcth; the scelidotherium, a somewhat smaller form; the great camel-like, yet odd-toed, macrauchenia; and the toxodon, as large as a hippopotamus, yet having a strange resemblance to the little rodents. All these belonged to geological deposits not far anterior to the present age. The collections of living vertebrates were less profoundly interesting, but the number of new species was large; and the habits and localities being recorded by so good an observer, gave them additional value.

The fossil mammals were given by the generous traveller to the London College of Surgeons, the mammals and birds to the Zoological Society, the reptiles to the British Museum, and the fishes to the Cambridge Philosophical Society. Nor was this all. The collections of insccts, shells, and crustacea were described by many able specialists in scientific publications. The flowering plants were described by Hooker, and the non-flowering by Berlieley; and, altogether, no expedition ever yielded a more solid result to the scientific naturalist, while fur- 
nishing a delightful narrative to the general reader, and laying the foundation for generalisations of surpassing importance to all thinking minds.

It was evident to many geologists that the greatest value would attach to the full record of the geological observations made by the gifted young secretary of the Geological Society. A year after the publication of the Journal the first portion of these observations, dealing with coral reefs, was almost ready, but the continued illhealth of the author dclayed the publication till $\mathrm{I}_{4}{ }^{2}$. When it appeared, under the title of "The Structure and Distribution of Coral Reefs," its success was immediate and complete.

Ever since their first description by voyagers, marvel had been expressed at the strange and beautiful phenomena presented by coral islands. Coral, as being built up by the tireless labours of innumerable so-called "insects," or "worms," had become associated with romantic ideas. It really consists of the internal skeletons of coral-polyps, allied to the sea anemone. Captain Basil Hall, in his "Voyage to Loo Choo," looking with the eyes of one ignorant of zoology, had credited the building of coral reefs to all kinds of creatures which lived on and near the coral after it had been made; and his erroneous views had been amplified and developed by James Montgomery, in his "Pelican Island," into the most fantastically incorrect description that ever versifier penned. Sad to relate, his lines were often quoted, as if correct, by scientific men in pre-Darwinian times.

Nothing gives clearer evidence of the power of mind which Darwin had already attained when voyaging round 
the world than the originality of his views on coral reefs. The lagoon islands, or atolls, he describes as "vast rings of coral rock, often many leagues in diameter, here and there surmounted by a low verdant island, with dazzling white shores, bathed on the outside by the foaming breakers of the ocean; and, on the inside, surrounding a calm expanse of water which, from reflection, is of a bright, but pale, green colour." Keeling atoll, outside which, at less than a mile and a half distance, no bottom was found with a line 7,200 feet in length, having been fully described, and an account given of all other known atoll systems, the peculiarities of the great barrier reef of North-east Australia, and that of New Caledonia, were recounted. Off the latter, no bottom was found, at two ships' length from the reef, with a line 900 fect long. With these were linked the smaller reefs of Tahiti and others, where considerable islands are more or less completely surrounded by them. Next, the fringing or shore reefs, at first sight only a variety of barrier reefs, were clearly distinguished from them by the absence of an interior deep-water channel, and their not growing up from an immense, but from a moderate depth of water.

The remarkable fact was pointed out by Darwin that all coral islands are within a little more than 30 degrees of the Equator, but that, at the same time, they are absent over certain larger areas within the tropical seas. There are none on the West Coast of South America, nor on the West Coast of Africa. In this portion of his work we have another significant sentence bearing on the struggle for existence. In discussing the apparently capricious 
distribution of coral reefs, he remarks that "the study of the terrestrial and better-known half of the world must convince every one that no station capable of supporting life is lost-nay more, that there is a struggle for each station between the different orders of nature." He describes the large fishes and the trepangs (holothurice) preying upon the coral-polyps, and shows how complex are the conditions which determine the formation of reefs on any shore. Perhaps no part of his work is more important than that in which he collects the evidence proving how rapidly coral masses grow, and that they for the most part cannot flourish in a greater depth of water than fifteen fathoms.

Reasoning upon the facts observed by himself and others Darwin now proceeded to upset the received theory that atolls were based upon submarine volcanic craters, and to substitute for it the view that there has been a prolonged and gradual subsidence of the areas upon which the atolls are based, and a corresponding upward growth of the reefbuilding corals. Thus fringing-reefs in time become barrier-reefs ; and barrier-reefs, when they encircle islands, are converted into atolls, or lagoon islands, as soon as the last pinnacle of land sinks beneath the surface of the ocean. The whole matter is summed up thus: "A magnificent and harmonious picture of the movements which the crust of the earth has within a late period undergone is presented to us. We see vast areas rising, with volcanic matter every now and then bursting forth through the vents or fissures with which they are traversed. We see other wide spaces slowly sinking without any volcanic outbursts; and we may feel sure that this sinking must 
have been immense in amount as well as in area, thus to have buried over the broad face of the ocean every one of these mountains above which atolls now stand like monuments, marking the place of their former existence." "No more admirable example of scientific method was erer given to the world," says Professor A. Geikie, "and even if he had written nothing else, this treatise alone would have placed Darwin in the very front of investigators of nature."

After thirty-two years' interval, a second edition of "Coral Reefs" appeared, in a cheaper form, in $\mathrm{I} \$ 74$. It is rare indeed for a scientific treatise to attain at once and maintain so long a position of such undisputed authority. The eminent German naturalist, Semper, in I 863 , criticised the general theory in consequence of his own careful examination of the Pelew Islands; but Darwin easily answered him by pointing to the cumulative evidence in favour of his own views. The only really important work on the subject, after Darwin's, was that of Professor J. D. Dana, the eminent American naturalist and geologist, on "Corals and Coral Islands," published in I872. Darwin, in the preface to his second edition, candidly acknowledged that he had not previously laid sufficient weight on the mean temperature of the sea in determining the distribution of coral reefs; but this did not touch his main conception. In fact, he maintained his ground undisturbed, and at the same time admired greatly Dana's book, which was the result of personal examination of more coral formations than perhaps any one man had ever studied, and which accepted Darwin's fundamental proposition, that lagoon islands or atolls 
and barricr-reefs have been formed during periods of subsidence. $^{\mathrm{x}}$

No such strikingly original theory is propounded in the sccond part of "The Geology of the Beagle," dealing chiefly with volcanic islands. St. Jago, in the Cape de Verde Islands; Fernando Noronha, Terceira, Tahiti, Mauritius, St. Paul's, Ascension, St. Helena, and the Galapagos are in turn more or less fully described, according to the opportunities the explorer had possessed. To some extent, as in the succeeding part, Darwin adapts his views on mountain elevation too closely to those enunciated by Elic de Beaumont. The third part of the geology of the Beagle, entitled "Geological Observations on South America," was not published till i 846 . Even this did not exhaust the contributions to geology made from the Beagle voyage, for it did not include the papers on the "Connection of certain Volcanic Phenomena in South America" ( $\left.\mathrm{I}_{3} S\right)$; on the "Distribution of Erratic Boulders" (I $\left.8_{4} \mathrm{r}\right)$; on the "Fine Dust which falls on

${ }^{x}$ Mr. John Murray's views, derived from the experience acquired in the voyage of the Challenger, and published in I880, tend to modify 1)arwin's conclusions to some cxtent. Mr. Murray says that it is now shown that many submarine mountains exist, which are usually volcanic, and which, being built upon by various forms of shcllbearing animals, could be raised to such a level that ordinary corals could build upon them. He concludes that probably all atolls are seated on submarine volcanocs, and thus it is not necessary to suppose such extensive and long-continued sulssidences as Darwin suggested. This vicw is also in harmony with Dana's views of the great antiquity and permancnce of the great ocean basin. See "The Structure and Origin of Reefs and Islands." By John Murray; Proc. Roy. Soc., Edin., x. 505-18 (abstract); also Nuture, xxii. $35 \mathrm{I}-5$. 
Vesscls" (I 845); and on the "Geology of the Falkland Islands" (I 846). A second edition of the two latter parts of "The Geology of the Beagle" was published in one volume in $\mathrm{s} \$ 76$.

Mcanwhile, after spending a few years of his early married life in London, during which he was often in illhealth, Darwin fixed his residence in 1842 at Down House, near Beckenham, Kent. 'The little village of Down, three or four miles from the Orpington railway station, was near cnough to London for convenient access, yet greatly sccluded and thoroughly rural. The traveller's roving days were over, and his infirmity of health prevented him from undertaking very fatiguing journeys. After the cessation of his active work for the Geological Society, Darwin's chief public appearance was when he spoke at the Oxford meeting of the British Association, in 1847 , when, strange to say, Ruskin was secretary of the Geological Section.

At Down then, situated some 400 feet above the sea level on a plateau of chalk, interrupted by wavy hollows with beech woods on the slopes, about forty years of Darwin's life were passed. Down House, one of the square red brick mansions of the last century, to which have bcen since added a gable-fronted wing on one side and a more squarely-built wing and pillared portico on the other, is shut in and almost hidden from the roadway by a high wall and bclt of trees. On the south side a walled garden opens into a quiet meadow, bounded by underwood, through which is seen a delightful view of the narrow valley beyond, towards Westerham.

One of the most admirable chapters of the well-knowi 
"Manual of Scientific Enquiry," published in I 849, for the use of the navy and travellers gerierally, and edited by Sir John Herschel, was Darwin's, on Geology. The explorer is here taught to make the most of his opportunities upon the soundest principles. The habits which the author had himself formed are inculcated upon the observer-copious collecting, accurate recording, much thinking. Nothing is omitted. Number-labels which can be read upside down must have a stop to indicate the right way up; every specimen should be ticketed on the day of collection; diagrams of all kinds should be made, as nearly as possible, to scale. "Acquire the habit of always seeking an explanation of every geological point met with." "No one can expect to solve the many' difficulties which will be encountered, and which for a long time will remain to perplex geologists; but a ray of light will occasionally be his rezerard, and the reward is ample." Truly an ample reward awaited the obscrver who could thus speak of the value of "a ray of light;" he certainly did, to use the concluding words of the essay, "enjoy the high satisfaction of contributing to the perfection of the history of this wonderful world."

Meanwhile Darwin had been carrying on a great research on the very peculiar order of crustacea, termed Cirripedia, better known as barnacles and acorn shells. $\mathrm{He}$ had originally only intended to describe a single abnormal member of the group, from South America, but was led, for the sake of comparison, to examine the internal parts of as many as possible. The British Museum collection was freely opened to him, and as the importance of studying the anatomy of many 
specimens became evident, the splendid collections of Messrs. Stutchbury, Cuming, and others were placed at his disposal, and he was permitted to open and to dissect unique specimens of great value. In fact, almost every naturalist of note who had any knowledge of the subject freely aided him, and the result was a masterly series of finely illustrated volumes; two on the living Cirripedia, issued by the Ray Society in $x_{5} \mathrm{I}$ and $\mathrm{I} 854$; and two on the fossil Cirripedia of Great Britain, by the Palæontographical Society, published in the same years. There is cvidence in these volumes that careful observations on the growth of these creatures had been made as far back as the visit to the Galapagos Islands in 1835 . In many respects these works are as masterly as any the author ever wrote. Considering the previous obscurity of the subject, the difficulties attending the research, the almost entire lack at that time of any general microscopical knowledge of tissues, and especially of those of embryos, Darwin's success is marvellous. The details are too technical for statenent here, but any one with a zoological training, who studies the strange complication of the reproductive systems, and the remarkable transformations which the young undergo, as told in these volumes, will appreciate more than ever the breadth and the solidity of the basis of patiently acquired knowledge which Charles Darwin had accumulated while his "Origin of Species" was taking shape.

At the anniversary meeting of the Royal Society in November, I853, a royal medal was presented to the author of "Coral Reefs" and the "Memoir on the Cirripedia," the president, the Earl of Rosse, eulogizing 
the former as one of the most important contributions to modern geology, and the latter as containing new facts and conclusions of first-rate interest. Finally, this chapter of Darwin's life may be closed with the tardy award of the Wollaston medal to him by the Geological Society, in February, 1859, when Professor John Phillips spoke of him as combining the rarest acquirements as a naturalist, with the qualifications of a first-class geologist, and as having by his admirable monograph on the fossil Cirripedia added much to a reputation already raised to the highest rank.

Yet even such a reputation could not secure fair treatment and impartial judgment for the coming book, the subject of which might be supposed to require supreme gifts of the very kind Darwin possessed. 


\section{CHAPTER IV.}

T F no other record of Darwin's twenty-two years (I 837 -

I 59) of life and thought after his return to England remained than the papers and books he published during that period, we should find enough to place him on a level with the most gifted biologists and geologists of his age. But all that time he was occupied with thoughts, researches, and experiments, of which the world at large perceived no fruits. Few persons suspected that a tremendous revolution in scientific thought was in preparation at the quiet country home at Down. New species of animals and plants were being described by naturalists at an alarming rate. The bulk of knowledge of specific characters and the necessity of specialisation bade fair to make every species-monger a dry and narrow pedant; and the pedants quarrelled about the characters and limits of their species.

In the later years of this period some rays of improvement shone out. To end the reign of Owen's misleading types and imaginary archetypes, there arose a wielder of two potent words, "morphology" and "biology," the sciences of form and of life, who showed that differences of adult form grew out of likeness and simplicity in the 
young; and that the life of plants and animals was one science, their study one discipline. What Huxley had begun to proclaim from the housetop, Darwin was meditating in secret; and much more. Let us see how he states the case in the famous modest opening of the

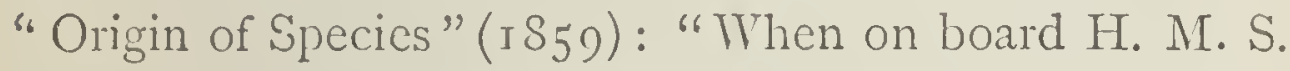
Beagle, as naturalist, I was much struck with certain facts in the distribution of the inhabitants of South America, and in the geological relations of the present to the past inhabitants of that continent. These facts seemed to me to throw some light on the origin of species-that mystery of mysteries, as it has been called by one of our greatest philosophers. On my return home, it occurred to me, in $\mathrm{I} \mathrm{S}_{37}$, that something might perhaps be made out on this question by patiently accumulating and reflecting on all sorts of facts which could possibly have any bearing on it. After five years' work I allowed myself to speculate on the subject, and drew up some short notes; these I enlarged in I844 into a sketch of the conclusions, which then scemed to me probable: from that period to the present day I have steadily pursued the same object. I hope that I may be excused for entering on these personal details, as I give them to show that I have not been hasty in coming to a decision." We learn also, independently, from the "Expression of the Emotions" (p. I 9 ), that Darwin as early as ${ }^{8} 8_{3} 8$ was inclined to believe in the principle of evolution, or the derivation of species from other and lower forms.

It is somewhat difficult to decide precisely what Darwin owed to his predecessors who believed in the mutability of species and doubted their separate creation; 
this is partly owing to his exceeding modesty. He was over-ready to acknowledge the value to himself of other people's ideas, and he under-estimated the strength of the illumination which his own mind threw upon those ideas, transforming them from guesses into probable hypotheses, confirming them by his vast and varied knowledge, and building a superstructure where they had laid but an uncertain foundation. The question was in the air; guessing replies of great interest were made by a few who doubted the received belief; but they were not satisfying answers and they did not effect a revolution. Goethe in Germany, Erasmus Darwin in England, ${ }^{\mathbf{x}}$ and

I It is worth while to reproduce here a few sentences from Erasmus Darwin's "Znonomia," showing how acutely he guessed in the direction of evolution.

"When we revolve in our minds, first, the great changes which we see naturally produced in animals after their nativity.... Secondly, when we think over the great changes introduced into various animals by artificial or accidental cultivation. . . . Thirdly, when we enumerate the great changes produced in the species of animals before their nativity.... Fourthly, when we revolve in cur minds the great similarity of structure which obtains in all the warm-blooded animals. ... Fifthly, from their first rudiment or primordium to the termination of their lives, all animals undergo perpetual transformations, which are in part produced by their own exertions; ... and many of these acquired forms or propensities are transmitted to their posterity. . . A great want of one part of the animal world has consisted in the desire of the exclusive possession of the female; and these have acquired weapons to combat each other for this purpose. . . The final cause of this contest amongst the males scems to be that the strongest and most active animal should propagate the species, which should thence become improved. Another great want consists in the means of procuring food, which has diversified the forms of all species of animals. . . A All which scem to have been gradually produced during many generations by the 
Geoffroy Saint Hilaire in France, came independently to similar conclusions as to the mutability of species; and Lamarck followed with several well-known works in I $80 \mathrm{I}-\mathrm{I} 5$, in which he upholds the doctrine that all species, including man, are descended from other species. As Darwin says, Lamarck first did the eminent service of arousing attention to the probability of all change in the organic, as well as in the inorganic world, being the result of law, and not of miraculous interposition. He saw the difficulty of distinguishing between species and varieties, the almost perfect gradation of form in some groups, and the great similarity of domestic breeds of animals to such species. He believed that some degree of change was produced by the physical conditions of life, the intercrossing of species, and by habits causing increased use or disuse of parts. Indeed he thought very many remarkable adaptations, such as that of the neck of the giraffe for browsing on trees, were the effect of habit. But he attributed, perhaps, more to a law of progressive development impressed on all forms of life,

perpetnal endeavour of the creatures to supply the want of food, and to have been delivered to their posterity with constant improvement of them for the purpose required. ... The third great want among animals is that of security, which seems much to have diversified the forms of their bodies and the colour of them. . . . The contrivances for the purposes of security extend even to vegetables.... Would it be too bold to imagine that in the great length of time since the earth began to exist . . . all warm-blooded animals have arisen from one living filament, which the Great First Cause endued with animality; ... possessing the faculty of continuing to improve by its own inherent activity, and of delivering down those improvements by generation to its posterity, world without end!" 
which thus would all in time gradually cease to be lowly, their place being taken by new forms continually or "spontaneously" generated.

It does not appear that Lamarck would by any means have sufficed to convince Darwin, judging from his references to him in his Journal and the "Origin." Here is the passage in which in the second edition of his Journal he refers to the blindness of the Brazilian Tucutuco, or Ctenomys, a rodent or gnawing mammal with the habits of a mole: "Considering the strictly subterranean habits of the Tucutuco, the blindness, though so common, cannot be a very serious evil; yet it appears strange that any animal should possess an organ frequently subject to be injured. Lamarck would have been delighted with this fact had he known it when speculating (probably with more truth than usual with him) on the gradually acquired blindness of the Aspalax, a gnawer living underground, and of the Proteus, a reptile living in dark caverns filled with water, in both of which animals the eye is in an almost rudimentary state, and is covered with a tendinous membrane and skin. . . . In the Tucutuco, which, I believe, never comes to the surface of the ground, the eye is rather larger (than in the mole), but often rendered blind and useless, though without apparently causing any inconvenience to the animal: no doubt Lamarck would have said that the Tucutuco is now passing into the state of the Aspalax and Proteus." Many years afterwards in the "Origin of Species" Darwin referred to the "erroneous views and grounds of opinion of Lamarck."

No doubt some impulse to Darwin's views in this 
direction would be due to his intercourse with Dr. Grant at Edinburgh, whose celebrated paper on the fresh-water sponge concludes with a declaration of his belief that species are descended from other species, and that they become improved in the course of modification. But previous to the occurrences of his voyage, we can find no stronger influence tending to make Darwin an evolutionist, than Lyell's "Principles of Geology," which, by showing constant and gradual change as the law of the world's history now as in past perrods, gave emphasis and point to all observations of change and succession in the living world. Indeed, in June, $18{ }_{3} 6$, before Darwin's voyage was over, Lyell writes to Sir John Herschel: "In regard to the origination of new species, I am very glad to find that you think it probable that it may be carried on through the intervention of intermediate causes. I left this rather to be inferred, not thinking it worth while to offend a certain class of persons by embodying in words what would only be a speculation. But the German critics have attacked me vigorously, saying, that by the impugning of the doctrine of spontaneous generation, and substituting nothing in its place, I have left them nothing but the direct and miraculous intervention of the First Cause, as often as a new species is introduced, and hence I have overthrown my own doctrine of revolutions carried on by a regular system of secondary causes. . . . When I first came to the notion, which I never saw expressed clsewhere, though I have no doubt it had all been thought out before, of a succession of extinction of species, and creation of new ones going on perpetually now, and through an indefinite period of the past, and to continue for ages to come, all 
in accommodation to the changes which must continue in the inanimate and babitable earth, the idea struck me as the grandest which I had ever conceived, so far as regards the attributes of the Presiding Mind."

In a succeeding paragraph, Lyell very remarkably foreshadows Darwin's "natural selection" and "struggle for existence." He speaks of a species being rendered more prolific in order to perpetuate its existence; "but this would perhaps make it press too hard upon other species at other times. Now if it be an insect it may be made in one of its transformations to resemble a dead stick, or a leaf, or a lichen, or a stone, so as to be somewhat less easily found by its enemies; or if this would make it too strong, an occasional variety of the species may have this advantage conferred on it; or if this would be still too nuch, one sex of a certain variety. Probably there is scarcely a dash of colour on the wuing or body of which the choice would be quite arbitrary, or which might not affect its duration for thousands of years." The significance of the last sentence is immense, and when we reflect that this bold but cautious thinker was in constant intercourse with Darwin, we can readily comprehend why the second edition of the Journal was so enthusiastically dedicated to Lyell. On page 48I of the "Origin of Species," Darwin acknowledges that the belief that species were immutable productions was almost unavoidable, as long as the history of the world was thought to be of short duration: which affords another proof how profoundly Lyell's views on the long duration of the past history of the globe, and its modification by the slow operation of existing causes, in- 
fluenced Darwin, and led him to comprehend how species might be modified.

We see Darwin, then, possessed of the idea that species are mutable, informed as to past and recent changes in the animal, plant, and physical world, seeking for causes which should suffice to produce modification of species by a continuous law. The next step in his progress was attention to domestic animals and cultivated plants. As he wrote in I864 to Hacckel, one of his most brilliant followers: "In South America three classes of facts were brought strongly before my mind. Firstly, the manner in which closely-allied species replace species in going southward. Secondly, the close affinity of the species inhabiting the islands near South America to those proper to the continent. 'This struck me profoundly, especially the difference of the species in the adjoining islets in the Galapagos Archipelago. Thirdly, the relation of the living Edentata and Rodentia to the extinct species. I shall never forget my astonishment when I dug out a gigantic piece of armour like that of the living armadillo. "Having reflected much on the foregoing facts, it secmed to me probable that allied species were descended from a common ancestor. But during several years I could not conceive how each form could have been modified so as to become admirably adapted to its place in nature. I began, therefore, to study domesticated animals and cultivated plants, ${ }^{\mathrm{T}}$ and after a time perceived

I In this study Darwin came into communication, as early as I 839 , with the IIon. and Rev. WV. Herbert, afterwards Dean of Manchester, and received from him a personal account of his experiments on lyybricls. It was Herbert who, as early as 1922 , in the fourth 
that man's power of selecting and breeding from certain individuals was the most powerful of all means in the production of new races. Having attended to the habits of animals, and their relations to the surrounding conditions, I was able to realise the severe struggle for existence to which all organisms are subjected; and my geological observations had allowed me to appreciate, to a certain extent, the duration of past geological periods. With my mind thus prepared, I fortunately happened to read Malthus's 'Essay on Population;' and the idea of natural selection through the struggle for existence at once occurred to me. Of all the subordinate points in the theory, the last which I understood was the cause of the tendency in the descendants from a common progenitor to diverge in character." $x$

Malthus taught the inevitable tendency of all animal life to increase beyond the means of subsistence, and expounded the checks which begin to act when population increases too rapidly. But his book had lain unfruitful to naturalists since I793, until Darwin read it,

volume of the "Hortieultural Transactions," and in his work on the Amaryllidacea, I837, deelared that horticultural experiments have established, beyond the possibility of refutation, that botanical speeies are only "a higher and more permanent class of varieties." IIe extended the same view to animals, and believed that single speeies of each genus were originally ereated in a highly plastic condition, and that these have produced, chiefly by intercrossing, but also by variation, all our existing species.

"The first portion of this important letter is quoted from the English translation of Hacekel's "History of Creation," I876; the second portion from O. Selmidt's "Doctrine of Descent and Darwinism," having been re-written by Darwin from the German text. 
and with his special knowledge evolved from it the brilliant idea of the preservation of better-equipped races in the struggle for life, or, as Herbert Spencer put it, the survival of the fittest. At one bound the gloomy revelations of misery which the "Essay on Population" contained, were exchanged for the bright view of perpetual progress and improvement as being necessitated and brought about by the very struggle which ensued upon the natural increase of animal and plant life. Instead of struggle and pain, producing starvation and extinction merely, struggle and pain were seen as the conditions of development and improvement; the death of the lower, the life of the higher.

It is less profitable here to attempt to sketch the history of ideas of evolution in general, because that history as now revealed by research, and as detailed by many writers, was not the path along which Darwin travelled. Indeed, many of these ideas were not disinterred, and certainly were not brought to Darwin's notice till after the publication of the "Origin of Species." True he read Robert Chambers's "Vestiges of Creation," which, with its "powerful and brilliant style," although displaying in its earlier editions "little accurate knowledge and a great want of scientific caution," Darwin acknowledges to have done excellent service in calling attention to the subject, in removing prejudice, and in preparing the ground for the reception of analogous views. Herbert Spencer, in his Essay on the Development Hypothesis, first published in The Leader in March, 1852, and republished in his "Essays" (first series, I858), argued that species have been modified owing to change of cir- 
cumstances, basing his argument upon the analogy of domestic animals and plants, the changes which the embryos of many species undergo, and the difficulty of distinguishing species and varieties.

But we need not here dwell on the works of these thinkers, important as they are to the general history of evolutionary thought, because Darwin's speculations had taken form long before, and he could be but slightly indebted to them. Far in advance of them he was at work collecting and testing the facts which alone could win general support for his views, and experimenting incessantly with the same object in view. Lyell and Hooker were in his confidence, and in Lyell's letters we meet with references such as the following, dated November I 3, I 854: "You probably know about this (the remarkable orchid, Catasetum), which will figure in C. Darwin's book on 'Species,' with many other 'ugly facts,' as Hooker, clinging like me to the orthodox faith, calls these and other abnormal vagaries," showing at the same time how completely Darwin was the leader, while his friends, advanced as they were, hung back. Again (Lyell to Hooker, July 2.5, I 856): "Whether Darwin persuades you and me to renounce our faith in species (when geological epochs are considered) or not, I foresee that many will go over to the indefinite modifiability doctrine."

Further light is thrown on the progress of ideas on species by Sir Joseph Hooker's admirably written Introductory Essay to the "Flora Novæ Zelandix," dated November, 1853, in which he discusses among other questions, "The Limits of Species; their Dispersion and 
Variation." While still adhering on the whole to the origin of species from single parents, or from one pair, and the permanence of specific characters, he insists that species vary more, and are more widely distributed, than is generally admitted, and that their distribution has been brought about by natural causes. In this essay he makes the following statements: "Mr. Darwin not only directed my earliest studies in the subjects of the distribution and variation of species, but has discussed with me all the arguments, and drawn my attention to many of the facts which I have endeavoured to illustrate in this essay. I know of no other way in which I can acknowledge the extent of my obligation to him, than by adding that I should never have taken up the subject in its present form but for the advantages I have derived from his friendship and encouragement."

Appropriately enough, it was through Lyell and Hooker that the new theory was introduced to the public, and it was owing to them that Darwin did not obliterate his own claims to priority, and give them over to Alfred Russel Wallace, who had independently come to similar conclusions. The letter, dated June 30,1858 , in which the announcement was conveyed to the Linnean Society, deserves quotation, as being the authoritative and accurate record of the circumstances which launched the "Origin of Species" upon the world:

"The accompanying papers, which we have the honour of communicating to the Linnean Society, and which all relate to the same subject, viz., "The Laws 
which affect the Production of Varieties, Races, and Species,' contain the results of the investigations of two indefatigable naturalists, Mr. Charles Darwin and Mr. Alfred Wallace.

"These gentlemen having, independently and unknown to one another, conceived the same very ingenious theory to account for the appearance and perpetuation of varieties and of specific forms on our planet, may both fairly claim the merit of being original thinkers in this important line of inquiry; but neither of them having published his views, though Mr. Darwin has been repeatedly urged by us to do so, and both authors having now unreservedly placed their papers in our hands, we think it would best promote the interests of science that a selection from them should be laid before the Linnean Society.

"Taken in the order of their dates, they consist of -

"I. Extracts from a MS. work on species, by Mr. Darwin, which was sketched in 1839 , and copied in 1844 , when the copy was read by Dr. Hooker, and its contents afterwards communicated to Sir Charles Lyell. The first part is devoted to 'The Variation of Organic Beings under Domestication and in their Natural State'; and the second chapter of that part, from which we propose to read to the Society the extracts referred to, is headed, ' On the Variation of Organic Beings in a State of Nature; on the Natural Means of Selection; on the Comparison of Domestic Races and true Species.'

"2. An abstract of a private letter addressed to Professor Asa Gray, of Boston, U.S., in October, 1857 , hy Mr. 
Darwin, in which he repeats his views, and which shows that these remained unaltered from I 839 to $185 \%$

"3. An essay by Mr. Wallace, entitled 'On the Tendency of Varieties to depart indefinitely from the Original Type.' This was written at Ternate in February, I 858 , for the perusal of his friend and correspondent, Mr. Darwin, and sent to him with the expressed wish that it should be forwarded to Sir Charles Lyell, if Mr. Darwin thought it sufficiently novel and interesting. So highly did Mr. Darwin appreciate the value of the views therein set forth, that he proposed, in a letter to Sir Charles Lyell, to obtain Mr. Wallace's consent to allow the essay to be published as soon as possible. Of this step we highly approved, provided Mr. Darwin did not withhold from the public, as he was strongly inclined to do (in favour of Mr. Wallace) the memoir which he had himself written on the same subject, and which, as before stated, one of us had perused in 1844 , and the contents of which we had both of us Deen privy to for many years. On representing this to Mr. Darwin, he gave us permission to make what use we thought proper of his memoir, \&c.; and in adopting our present course, of presenting it to the Linnean Society, we have explained to him that we are not solely considering the relative claims to priority of himself and his friend, but the interests of science generally; for we feel it to be desirable that views founded on a wide deduction from facts, and matured by years of reflection, should constitute at once a goal from which others may start, and that, while the scientific world is waiting for the appearance of Mr. Darwin's complete work, some of the 
leading results of his labours, as well as those of his able correspondent, should together be laid before the public."

In these papers, read on July I, I 85 , Darwin's share amounts to little more than six pages, yet within this space he describes the geometrical rate of increase of animals, the checks that occur, the effects of changed conditions, the natural selection of the better equipped forms resulting from the struggle for existence, and the influence of sexual selection. Wallace insists on essentially the same view, which he calls that of progression and continued divergence. "This progression, by minute steps, in various directions, but always checked and balanced by the necessary conditions, subject to which alone existence can be preserved, may, it is believed, be followed out so as to agree with all the phenomena presented by organised beings, their extinction and succession in past ages, and all the extraordinary modifications of form, instinct, and habits which they exhibit." Those who read Wallace's original essay can best appreciate the extraordinary simplicity and nobility of character which inclined the elder naturalist, who had so long held the same views, to step aside in favour of the younger man, who from different researches was led to such similar conclusions. It may here be added that Hooker, in the Introductory Essay to the "Flora Tasmanix," dated November 4, I 859, before the publication of the "Origin of Species," but after seeing much of it in manuscript. accepted and advocated the view that species are derivative and mutable, and developed it as regards the geographical distribution of plants. 


\section{CHAPTER V.}

DARWIN'S great work "On the Origin of Species by means of Natural Selection, or the Preservation of Favoured Races in the Struggle for Life," was published in November, 1859. It begins with the simplest narrative of the events leading to its publication, and an apology for the imperfection of "this abstract." The author is well aware, he says, that on most points he deals with, facts can be adduced which often apparently lead to conclusions directly opposite to his own. He states clearly the important truth that a mere belief in the origin of species by descent from other species is unsatisfactory until it can be shown how species can have been modified so as to acquire their present remarkable perfection of structure and coadaptation. Consequently cases of observed modification of species are of the highest value, and precedence is given to the variation of animals and plants in a state of domestication.

The individuals belonging to the same variety of any of our long-cultivated animals or plants differ much more from each other than the individuals of any one species or variety in a state of nature. Darwin explains this by 
the changed conditions of their life, excess or changed quality of food, climate, changed habits, \&c. Thus man has effected remarkable changes in many species by consciously or unconsciously selecting particular qualities in the animals or plants kept for use or beauty. Domestic productions seem in fact to have become plastic in man's hands, and the inheritance of acquired qualities by offspring is reckoned on as almost certain. The breeds of cattle, poultry, dogs, and pigeons, are striking examples.

Darwin, as he tells us, kept every breed of domestic pigeons he could purchase or obtain, in order to study their variations. In this he was himself reverting to the associations of childhood, when the beauty, variety, and tameness of The Mount pigeons at Shrewsbury were well known.

We can imagine the astonishment with which the "eminent fanciers" and members of the London Pigeon Clubs, whose acquaintance the great naturalist cultivated, received the simplicity, yet depth, of his inquiries, as he came among them day after day, utilising all their lore, and yet continually asking what they neither knew nor suspected the drift of. He began his study with a prepossession against the idea of the immense diversity of modern pigeons having originated from one common stock. Yet if such modification has taken place in any creature, pigeons may furnish an example, for they have been kept and bred for thousands of years, being recorded in Egypt about 3000 B.c., and Pliny relates that their pedigree and race could be reckoned by the Romans of his time. "We cannot suppose that all the breeds were suddenly produced as 
perfect and as useful as we now see them; indeed, in several cases we know that this has not been their history. The key is man's power of accumulative selection; nature gives successive variations; man adds them up in certain directions useful to him." This is an undoubted fact, to which breeders and fanciers give far more emplatic testimony even than Darwin. As Lord Somerville said, speaking of what breeders have done for sheep, "It would seem as if they had chalked upon a wall a form perfect in itself, and then had given it existence."

Side by side with conscious selection goes unconscious. Two breeders, breeding from similar stock, aiming at the same end, will get different results. Aiming at a particular result, they find that with it is associated some other of which they had not dreamed. Thus through long ages our cultivated vegetables and flowers have been produced, by always selecting the best variety, and sowing its seeds. The fact which Darwin notes, that our cultivated plants and domestic breeds date from so ancient a time that we know really nothing of their origin, has an important bearing on the great antiquity of man, then scarcely imagined, now generally accepted; seeing that all domestic development depends on a variability in living creatures, which man can not produce, but can only work upon.

That variation of species occurs in a state of nature Darwin proves not only by recorded facts, but by a consideration of the chaotic condition of species-description, owing to the differences between authors as to what are species and what are varieties, one observer describing a 
dozen species where another reckons only one. If such divergence of opinion is possible between good observers, it is evident that there is no sufficiently clear rule for deciding what a species is, although for centuries naturalists have laboured to establish them. If species vary continually, and become modified, then this difficulty is explained.

But what is there in nature to answer to the breeder's selection? Here comes in Darwin's remarkable application and amplification of Malthus's principle of population. "Nothing is easier," he says, "than to admit in words the truth of the universal struggle for life, or more difficultat least I have found it so-than constantly to bear this conclusion in mind. Yet unless it be thoroughly engrained in the mind, I am convinced that the whole economy of nature, with every fact on distribution, rarity, abundance, extinction, and variation will be dimly seen or quite misunderstood. We behold the face of nature bright with gladness; we often see superabundance of food; we do not see, or we forget, that the birds which are idly singing round us mostly live on insects or seeds, and are thus constantly destroying life; or we forget how largely these songsters, or their eggs, or their nestlings are destroyed by birds and beasts of prey; we do not always bear in mind, that though food may be now superabundant, it is not so at all seasons of each recurring year." The proofs given of the enormous rate at which animals and plants tend to increase in numbers are very striking; even the elephant, the slowest breeder of all animals, would increase from one pair to fifteen millions in the fifth century, if no check existed. 
Thus every animal and plant may be said to struggle for existence with those with which it competes for space, food, light, air. The numbers are kept down by heavy destruction at various periods of life. Take the case of seedling plants. Darwin had a piece of ground three feet long and two feet wide dug and cleared, so that no grown plants existed to check the growth of seedlings of native plants as they came up. He counted and marked all that came up, and out of 357 no fewer than 295 were destroyed, chiefly by slugs and insects. So in a little plot of long-mown turf, allowed to grow freely, out of twenty species nine perished in the struggle. Many further personal observations of the author are given : such as that the winter of $1854-5$ destroyed four-fifths of the birds in his own grounds; that he has sometimes failed to get a single seed from wheat or other plants in his garden.

On the estate of a relative in Staffordshire the changes consequent on planting several hundred acres with Scotch fir were remarkable. In twenty-five years twelve species of conspicuous plants, and six different insectivorous birds had become settled and flourishing inhabitants in the plantations. The characteristic of the philosopher, who sees in the unconsidered trifles of others the material for his choicest discoveries, is well exemplified in his mode of observing the results of enclosure near Farnham, in Surrey. Here a multitude of self-sown firs sprang up in the enclosures, and Darwin went to examine into the cause of the strange phenomenon. Not a fir was in sight except some distant clumps. "But on looking closely between the stems of the heath, I found a multitude of seedling; and little trees, which had been perpetually browsed down 
by the cattle. In one square yard, at a point some hundred yards distant from one of the old clumps, I counted thirty-two little trees; and one of them, judging from the rings of growth, had during twenty-six years tried to raise its head above the stems of the heath, and had failed."

The interdependence of animal upon animal, of animal upon plant, of plant upon animal, is enforced in many ways by Darwin. For instance, the visits of humble-bees are of special importance to the welfare of red clover; humble-bees are largely destroyed by field-mice; cats largely destroy field-mice near villages, and so favou, humble-bees, and secondarily red clover. Every paragraph of the chapter on the struggle for existence is full of suggestion, and subversive of old imaginings. But Darwin's knowledge is to him slight, his ignorance profound. Yet, he says, notwithstanding our ignorance, "we may console ourselves with the full belief that the war of nature is not incessant, that no fear is felt, that death is generally prompt, and that the vigorous, the healthy, and the happy survive and multiply."

The great chapter on Natural Selection, or the preservation of favourable and the rejection of injurious variations, is crowded with striking passages. One of these vividly contrasts man's selection with nature's. "Man can act only on external and visible characters: nature cares nothing for appearances, except in so far as they may be useful to any being. She can act on every internal organ, on every shade of constitutional difference, on the whole machinery of life. Man selects only for his own good; nature only for that of the being she tends. 
Every selected character is fully exercised by her; and the being is placed under well-suited conditions of life. . . Under nature, the slightest difference of structure or constitution may well turn the nicely-balanced scale in the struggle for life, and so be preserved. How fleeting are the wishes and efforts of man! how short his time! and consequently how poor will his products be, compared with those accumulated by nature during whole geological periods. Can we wonder, then, that nature's productions should be far 'truer' in character than man's productions; that they should be infinitely better adapted to the most complex conditions of life, and should plainly bar the stamp of far higher zorkmanship?" The words in italics certainly are a good answer to those who think Darwin had any tendency to depreciate the marvels of nature by bringing them under the law of natural selection. But we shall gain further light on this subject later on.

The main argument may be summed up thus: if variations beneficial to any creature occur, which cannot be doubted, the individuals in whom they occur will have the best chance of surviving and transmitting their qualities to their offspring. This natural selection will tend to produce divergence of character among offspring, and to intensify differences until they equal those between species or even genera. The same tendency to improvement brings about the decay and ultimate extinction of many lower and unimproved forms of life.

One of the best examples of Darwin's style is in the passage comparing all members of the same class of beings to a great tree. "I believe this simile largely 
speaks the truth. The green and budding twigs may represent existing species; and those produced during each former year may represent the long succession of extinct species. At each period of growth all the growing twigs have tried to branch out on all sides, and to overtop and kill the surrounding twigs and branches, in the same manner as species and groups of species have tried to overmaster other species in the great battle for life. The limbs divided into great branches, and these into lesser and lesser branches, were themselves once, when the tree was small, budding twigs; and this connexion of the former and present buds by ramifying branches may well represent the classification of all extinct and living species in groups subordinate to groups. Of the many twigs which flourished when the tree was a mere bush, only two or three, now grown into great branches, yet survive and bearall the other branches; so with the species which lived during long-past geological periods, very few now have living and modified descendants. From the first growth of the tree many a limb and branch has decayed and dropped off; and these lost branches of various sizes may represent those whole orders, families, and genera which have now no living representatives, and which are known to us only from having been found in a fossil state. As we here and there see a thin straggling branch springing from a fork low down in a tree, and which by some chance has been favoured and is still alive on its summit, so we occasionally see an animal like the Ornithorhynchus or Lepidosiren, which in some small degree connects by its affinities iwo large branches of life, and which has apparently been saved from 
fatal competition by having inhabited a protected station. As buds give rise by growth to fresh buds, and these, if vigorous, branch out and overtop on all sides many a feebler branch, so by generation I believe it has been with the great Tree of Life, which fills with its dead and broken branches the crust of the earth, and covers the surface with its ever-branching and beautiful ramifica. tions."

What may be the laws controlling or producing variation Darwin candidly tells us he does not know. Some authors, he says, believe it to be as much the function of the reproductive system to produce individual differences, or very slight deviations of structure, as to make the child like its parents. But we certainly do not know the precise effect of any change of conditions, or what changes may be entailed in other parts of an organism by given clanges in one part. ${ }^{x}$

Why, if species are continually being modified, do we not see multitudes of transitional forms around us? How can the claborate structure and special habits of a bat have been formed by the modification of some animal of entirely different habits? How can the marvellous perfections of the human eye or that of one of the higher animals be supposed to have arisen through natural selection? These questions Darwin answers with powerful effect; but for the details we must refer the reader to the book itself. Incidentally he refers to objections urged against the view that every detail of

"Mr. Romanes, in his paper on "Physiological Selection" (Journal of the Linnean Society, Zoology, xix. 337-4II), has entered upon a most important discussion of this question. 
structure has been produced for the good of its possessor. He says plainly that if structures have been created for beauty in the eyes of man, or for mere variety, that is fatal to his theory. Yet he admits that many structures are of no direct use to their possessors; but they have been inherited from ancestors to whom they were of use, or they have arisen as correlated changes or in dependence on some other cause, where use and benefit have been primary.

In dealing with Instinct, we see Darwin personally studying ants and bees in their social habits. The idea of ants making slaves is to him "odious," which we can well understand after his references to slavery in South America. For three years, during June and July, he watched for many hours several ants' nests in Surrey and Sussex to see whether the slaves ever left the nest. One day he witnessed a migration of ants from one nest to another, the masters carefully carrying their slaves in their jaws. Again, he saw a party attempting to carry off slaves, succeeding, however, only in carrying their corpses off for food to the nest. Darwin then dug up a small group of pupx of the slave species from another nest, and put them down near the place of combat. They were eagerly seized and carried off by the tyrants, "who perhaps fancied that, after all, they had been victorious in their late combat." At the same time the slave-owners were able to distinguish instantly the pupæ of another species, showing much terror at sight of them; yet they ultimately took heart, and carried them off.

The cell-making instinct of the hive-bee, " the most wonderful of all known instincts," as Darwin terms it, was 
closely studied. The comb, "so beautifully adapted to its end," he enthusiastically admired. Yet he finds gradation among bees, and can imagine a method by which this beautiful construction has been gradually developed. His ideas were tested by setting bees to work on a solid piece of wax between two combs. The detailed account of these experiments is most instructive. It is quite charming to mentally follow the patient experimenter covering the edges of a single cell or the extreme margin of a growing comb with a thin layer of vermilion wax, and soon proving that many bees work in succession at a single cell by the rapid diffusion of the vermilion colouring as delicately as a painter could have done it, atoms of the coloured wax being removed and worked into the growing cells all round. " "It was really curious," Darwin says, "to note in cases of difficulty, as when two pieces of comb met at an angle, how often the bees would entirely pull down and rebuild in different ways the same cell, sometimes recurring to a shape which they had at first rejected." Here surely he was watching evolution in that slow, gradual process which appears to be the rule.

The castes of neuter ants, constituting as they did "by far the most serious special difficulty" Darwin had encountered, were similarly studied; but, as expected, gradations were found connecting them, although the extremes differ markedly in shape and size. The case is

I The full text of a large part of Darwin's original chapter on Instinct, which was omitted from the "Origin of Species" for the sake of condensation, is published in Mr. Romanes' "Mcntal Evolution in Animals," I883, which also contains many other observations by Darwin. 
most interesting, because these castes could only be developed if the variations which produced them were profitable to the community; "for no amount of exercise, or habit, or volition, in the utterly sterile members of a community could possibly have affected the structure or instincts of the fertile members, which alone leave descendants." This fact Darwin considers to be demonstrative against Lamarck's doctrine. At the same time, he admits that instincts are not always perfect, and are liable to make mistakes; and that no instinct has been produced for the exclusive good of other animals, but that each animal takes advantage of the instincts of others. It is to him "far more satisfactory to look at such instincts as the young cuckoo ejecting its foster-brothers, ants making slaves, the larve of ichneumonidæ feeding within the live bodies of caterpillars, not as specially endowed or created instincts, but as small consequences of one general law, leading to the advancement of all organic beings, namely, multiply, vary, let the strongest live and the weakest die." And here Darwin strikes one of his truest and most helpful notes. It is far more satisfactory to contemplate the rapine and war of nature as incidents which aid in working out a grand progress than as multitudinous cruelties, working no good, and in past ages of unknown length merely preluding the struggle and rapine through which man works out his rise or fall. If we agonise that we and our descendants may rise, life is worth living.

We cannot follow in detail the profoundly suggestive chapters on Hybridism, on the Imperfection of the Geological Record, on the Geological Succession of Organic Beings, on the Geographical Distribution, and 
on the Mutual Affinity of Plants and Animals. The first of these is one of the most difficult portions of the subject, and yet remains as a stumbling-block of science by its apparently inexplicable phenomena. The author throws on the past history of life on the earth the glamour of a fairy record, as he contemplates the infinite number of generations, which the mind cannot grasp, which must have succeeded one another in the long roll of years, the limited extent to which at any time fossil remains have been preserved, the immense amount of destruction of such records which has taken place; and hence argues most powerfully how improbable it is that the transitional stages from species to species should have been handed down and also (another rare chance) have been laid open to us. The great array of facts about extinct animals and plants is shown to be consistent with, and to be largely explained by, descent with modification, and to be incomprehensible on any other view. The eccentric contrasts and parallelisms displayed in the geographical distribution of plants and animals, the striking effects of barriers such as mountains, deserts, and seas, the phenomena of dispersion of living creatures, the indications of old glacial periods in the present distribution of Alpine plants, the strange distribution of freshwater animals and plants, the specialities of oceanic islands, and many other subjects of a like kind, are dealt with, all being turned to advantage, and shown to give strong support to Darwin's view.

Classification and classifiers are all made to bear testimony in the same direction. Morphology, which, in the hands of Huxley, Haeckel, Gegenbaur, Ray Lankester, 
and Balfour has, since the first issue of the "Origin of Species," grown into a coherent science, based on embryology, was even then seen by Darwin to yield evidence for his views. Examining very young animals, he found that in very distinct races of dogs and horses the young had by no means acquired their adult differences. He compared pigeons of extremely various breeds twelve hours after being hatched, and found their differences incomparably less than in the full-grown birds. How immensely morphological science has progressed since Darwin directed investigation into this profitable line would need a separate treatise to show; but it is not too much to say that embryology alone, without other evidence, would now suffice to prove the doctrine of descent with adaptive modification.

Rudimentary organs, again, strange appearances, like the presence of teeth in unborn whales and in the front of the upper jaws of unborn calves, the rudimentary wings of many insects, the rudimentary stamens or pistils of many flowers, are all swept into the Darwinian net. "Nothing can be plainer than that wings are formed for flight; yet in how many insects do we see wings so reduced in size as to be utterly incapable of flight, and not rarely lying under wing-cases, firmly soldered together?" These phenomena are all explicable if descent with modification is true.

Approaching the close of his work, the author expressed his doubts of being able to convert naturalists of long standing to his views; but based his main hopes on young and rising men approaching these questions without prejudices. He put some puzzling questions, however, 
to those who might oppose him. Did they really believe that at innumerable periods in the earth's history certain atoms had been commanded suddenly to flash into living tissues? Were animals and plants created as eggs or seed or as full grown? At each act of creation was one individual or were many produced? For himself, he came to the conclusion that all organic beings had descended from some one primordial form into which life was first breathed.

On this view Darwin predicted that a great increase of interest in many departments of natural history would arise. "When we no longer look at an organic being as a savage looks at a ship, as at something wholly beyond his comprehension; when we regard every production of nature as one which has had a history; when we contemplate every complex structure and instinct as the summing up of many contrivances, each useful to the possessor, nearly in the same way as when we look at any great mechanical invention as the summing up of the labour, the experience, the reason, and even the blunders of numerous workmen; when we thus view each organic being, how far more interesting-I speak from experience-will the study of natural history become. . . . The whole history of the world, as at present known, although of a length quite incomprehensible to us, will hereafter be recognized as a mere fragment of time compared with the ages which have elapsed since the first creature, the progenitor of innumerable extinct and living descendants, was created. . . We may look forward with some confidence to a secure future of equally inappreciable length. And as natural selection works solely 
by and for the good of each being, all corporeal and mental endowments will tend to progress towards perfection." The concluding sentence of the "Origin of Species" has become one of our classical quotations. "There is grandeur in this view of life, with its several powers, having been originally breathed into a few forms or into one; and that, whilst this planet has gone cycling on according to the fixed law of gravity, from so simple a beginning endless forms most beautiful and most wonderful have been, and are being, evolved."

This is not the place to give a history of the criticisms and discussions which arose in regard to "The Origin of Species," especially as Darwin himself took no public part in them, except by the alterations made in successive editions. As indicating the tone of prominent critical organs, we may note that The Athencum (November i9, I 859) acknowledges there is something poetical in the theory. "If a monkey has become a man, what may not a man become?" Neither book, author, nor subject being ordinary, "the work deserves attention." The Edinburgh Reviezu considered that the author left the question very nearly where he found it. Failing to find original observations adequate even to give a colour to the hypothesis, the reviewer sought to find flaws in the author's mode of reasoning, and concluded that "we are called upon to accept a hypothesis on the plea of want of knowledge." Defective information, vagueness, and incompleteness are charged upon the man whom we now delight to honour; "intellectual husks," we are told, are all that he offers. Professor Huxley, who lectured at the Royal Institution, on February I0, I 860, on "Species and 
Races and their Origin," and brought forward Darwin's investigations as exemplifying that application of science to which England owes her greatness, was told that it more truly paralleled "the abuse of science to which a neighbouring nation-some seventy years since-owed its temporary degradation." And the professor was accused of audaciously seeking to blind his audience. Samuel Wilberforce, then Bishop of Oxford, was equally denunciatory in The Quarterly. He hopes that "this flimsy speculation" will be completely put down. "It is a dishonouring view of nature. . . Under such influences," says the courtly bishop, "a man soon goes back to the marvelling stare of childhood at the centaurs and hippogriffs of fancy; or, if he is of a philosopnic turn, he comes, like Oken, to write a scheme of creation under a 'sort of inspiration,' but it is the frenzied inspiration of the inhaler of mephitic gas. The whole world of nature is laid for such a man under a fantastic law of glamour, and he becomes capable of believing anything; and he is able, with a continually growing neglect of all the facts around him, with equal confidence and equal delusion, to look back to any past and to look on to any future." I

The Saturday Review was much more moderate, by no means sharing the anxiety of those who regarded evolutionary theories as hostile to Christianity. The author is said

${ }^{x}$ The reader will thus be able to judge for himself how far Darwin's "Origin of Species" gained, "from the very first outset, universal respect and a fair hearing," as Mr. Grant Allen, with singular forgetfulness, states ("Darwin," p. II2). The violence of the attacks made upon Darwin by the majority of religious and orthodox journals is well known. 
to have encountered the difficulties of his theory "with admirable skill and ability," and though The Saturday remained unconvinced of his general argument, yet it acknowledged itself "persuaded that natural selection must henceforward be admitted as the chief mode by which the structure of organised beings is modified in a state of nature;" and thought it very possible that, through its agency, considerable groups of nearly allied species might have been derived from a single progenitor: but there The Saturday stopped, believing in limits to this power.

The second edition of "The Origin of Species," which appeared in January, I860, only six weeks after the first, contained but few alterations ; the third, in March, I86I, had received extensive additions and corrections. The most important of these discussed the so-called tendency of organisation to advance, and explained the present coexistence of high and lowly organised forms. A valuable historical sketch of the modern progress of opinion on the subject, from Lamarck's time, was prefixed to the book. It was further enlarged in subsequent editions, as evidences accumulated that various thinkers had independently adopted the evolution theory, or the more special one of natural selection. Notable instances of anticipation were those of Dr. Wells, who, in a paper read before the Royal Society in $\mathrm{I} 8 \mathrm{~s} 3$, but not published till I 8 I 8 , had expressed the opinion that all animals tend to vary; that agriculturists improve breeds by selection; and that what they do by art "seems to be done with equal efficacy, though more slowly, by nature, in the formation of varieties of mankind." He then 
goes on to exemplify the survival of the fittest, though in

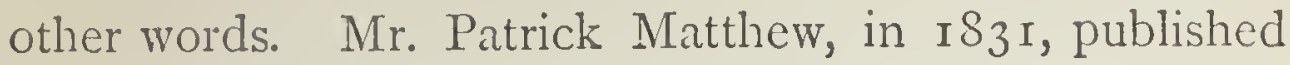
a work on "Naval Timber and Arboriculture," in which he expressed, in scattered passages, a view nearly resembling Darwin's.

The fourth edition of "The Origin," in 1866, was longer, by fifty pages, than its predecessor. Among the additions may be mentioned a fuller treatment of the argument from embryology, which was made stronger by later investigations. The fifth edition (1869) was comparatively little increased in bulk, though altered in many details. In particular it contained a somewhat important change relating to the extent of the influence of natural selection. This is also referred to in "The Descent of Man" (first edition, vol. i. pp. 152-3), where the author says he had not formerly considered sufficiently the existence of many structures which appeared to be neither beneficial nor injurious, and had attributed too much to natural selection. "I was not able," he says, "to annul the influence of my former belief, then widely prevalent, that each species had been purposely created; and this led to my tacitly assuming that every detail of structure, excepting rudiments, was of some special, though unrecognised, service. . . . If I have erred in giving to natural selection great power, which I am far from admitting, or in having exaggerated its power, which is in itself probable, I have, at least, as I hope, done good service in aiding to overthrow the dogma of separate creations." The sixth edition (I872), in smaller type, was considerably revised and altered, and remains permanent. A glossary of scientific terms was added by Mr. W. S. 
Dallas. A new chapter was inserted after the sixth, and entitled "Miscellaneous Objections to the Theory of Natural Selection." It was partly derived from modified portions of chapter iv. of former editions, but the latter and larger part was new, and relates chiefly to the supposed incompetency of natural selection to account for the very early stages of useful structures. Numerous cases, such as the development of the giraffe's neck, the baleen of the whale, the mammary glands, \&c., are admirably discussed. Causes preventing the acquisition, through natural selection, of useful structures in many cases are dealt with, and reasons given for disbelieving in great and sudden modifications. In the concluding chapter Darwin further admits that he had formerly underrated the frequency and importance of use and disuse of parts, of the direct action of external conditions, and of variations which seem to us, in our ignorance, to arise spontaneously. He alludes to misrepresentations of his views, and calls attention to the fact that, in the first edition, at the close of the introduction, he stated his conviction that natural selection had been the main, but not the exclusive means of modification. "This has been of no avail. Great is the power of steady misrepresentation; but the history of science shows that, fortunately, this power does not long endure." This is Darwin's almost sole allusion in his works to the persistence with which views not his had been attributed to him, or he had been calumniated for views he did hold. But in his own lifetime-nay, within fifteen years-he witnessed a sufficiently satisfying revolution. "I formerly spoke to very many naturalists on the subject of evolution, and never 
once met with any sympathetic agreement. It is probable that some did then believe in evolution, but they were either silent or expressed themselves so ambiguously, that it was not easy to understand their meaning. Now things are wholly changed, and almost every naturalist admits the great principle of evolution " "Origin," sixth edition, p. 424). At present the sale of the book in this country approaches forty thousand copies. Its sale in America has been very large; and numerous translations into German, French, Italian, Russian, Dutch, and Swedish, and even into Japanese and Hindustani, have been largely sold. It must always be one of the most valued of all English classics. 


\section{CHAPTER VI.}

W

E have already gathered much concerning Darwin's mental and moral fibre in our survey of his works. Let us make some further acquaintance with his personality as known to his friends. Outwardly he appeared a man of powerful physique, standing six feet high, with prominent forehead and over-arching brow, and keen, deep-set eyes in which resolute strength and piercing insight were indicated. Apart from his persistent infirmity, he was actively disposed, as indeed is evident from the laborious journeys he undertook during his travels. Field sports, including hunting, were among the recreations of his more active years. But through all his work or recreation the imperious conditions necessitated by his infirmity of stomach had to be considered, and nothing but the most rigorous care could possibly have enabled him to achieve what he did. On many days he could not work at all, and on many others two or three hours were his limit. And what but his own system, his own orderliness and perseverance could have accomplished his task? In preparing his books he had a special set of shelves for each, standing on or near his writing-table, one shelf for each chapter. The maxim, 
"Early to bed, and early to rise," was his essentially, and regularity kept all balanced. Rising at six, he took a cold plunge bath, breakfasted simply, and took a first walk, beginning work often at eight. "Later in the day," I quote from Mr. Woodall's pleasant pages, "he generally walked again, often in his own grounds, but sometimes further afield, and then generally by quiet footpaths rather than frequented roads. The walks at one time were varied by rides along the lanes on a favourite black cob, but some years before his death his four-footed friend fell, and died by the roadside, and from that day the habit of riding was given up. Part of the evening was devoted to his family and his friends, who delighted to gather round him to enjoy the charm of his bright intelligence, and his unrivalled stores of knowledge. To Down, occasionally, came distinguished men from many lands; and there in later years would sometimes be found the younger generation of scientific students, looking up to the great naturalist with the reverence of disciples, who had experienced his singular modesty, his patient readiness to listen to all opinions, and the winning grace with which he informed their ignorance and corrected their mistakes. In the midst of all the delights of home and the demands of study, Darwin kept an open mind for public affairs. He united the earnest politician with the patient student: a rare combination, which supplies another proof of his largeness of heart and sympathy with his fellow men. In the village of Down he was liked by everybody, old and young, and in his own household the same servants lived year after year under his roof. One of them, 
Margaret Evans, who assisted in nursing him in his last illness, had come to Down nearly forty years before, from Shrewsbury, where her uncle and aunt were in Dr. Darwin's service."

At Down the family in time numbered nine children, two, however, not surviving childhood; one died in I 842 , another in 1858 . His five sons have already attained distinction or positions of influence. The eldest, William Erasmus, became a banker in Southampton; the second, George, was second Wrangler and Smith's Prizeman at Cambridge in 1868 , became a Fellow of Trinity, and is now Plumian Professor of Astronomy at his university, having early gained the Fellowship of the Royal Society for his original papers bearing on the evolution of the universe and the solar system, and many other subjects of high mathematical and philosophical interest. His third son, Francis, gained first-class honours in the Cambridge Natural Science 'Tripos in I870, and is likewise a Fellow of the Royal Society, in recognition of his original botanical investigations. The fourth, Leonard, an officer in the Royal Engineers, has done valuable astronomical work. The fifth, Horace, has devoted himself to mechanical science, and has largely aided in developing the Cambridge Scientific Instrument Company.

The great thinker, fulfilling his duties as head of a family with singular success, charged with the burden of new thoughts and observations, slowly perfecting his life work, had neither time nor inclination for controversy. He set himself to publish facts, which by their accumulation tended to clench his arguments. Soon after the 
"Origin of Species" he had in course of publication several important botanical papers, on the two forms of flower in the Primrose genus (1862), and in the genus Linum (flax), 1863 , on the forms of Loosestrife, 1864 , all published in the Linnean Society's Journal.

In $r 862$ he brought out his first botanical book, the "Fertilisation of Orchids," more fully entitled, "On the various Contrivances by which Orchids are Fertilised by Insects." These most singular flowers had long attracted great attention owing to their peculiar shapes and often their great beauty, while their marked deviation from typical forms of flowers perplexed botanists extremely. The celebrated Robert Brown, in a well-known paper in the Linnean Society's Transactions, I833, expressed the belief that insects are necessary for the fructification of most orchids; and as far back as I 793, Christian Sprengel (in "The Newly Discovered Secret of Nature") gave an excellent account of the action of the several parts in the genus Orchis, having discovered that insects were necessary to remove the pollen masses. But the rationale of the process was not fully known until Darwin revealed it, and illuminated it by the light of natural selection. He had, in the "Origin of Species," given reasons for the belief that it is an almost universal law of nature that the higher organic beings require an occasional cross with another individual. He here emphasised that doctrine by a series of proofs from a peculiar and otherwise inexplicable order of plants, and showed that the arrangements by which orchids are fertilised have for their main object the fertilisation of the flowers with pollen brought by insects from a distinct plant. 
In the group to which our common orchids belong, remarkable adaptations for securing that the pollen masses brought from another flower solely through the visits of insects shall reach their precise destination, were brought to light. "A poet," says Darwin, "might imagine that whilst the pollinia were borne through the air from flower to flower, adhering to an insect's body, they voluntarily and eagerly placed themselves in that exact position in which alone they could hope to gain their wish and perpetuate their race." As he had examined all the British genera, Darwin's conclusions were indubitable. He had patiently watched for hours on the grass to notice insects' visits, had counted the fertilised flowers on many spikes, the fertilised spikes on many plants, had dissected and redissected the flowers till he saw how the fertilisation must absolutely be effected; and utilising the enthusiasm of orchid growers, had excited them to do the same, till his storehouse of facts was full.

On examining the exotic forms of orchids, which are so conspicuous in our conservatories, still more striking facts presented themselves. In the great group of the Vandeæ, relative position of parts, friction, viscidity, elastic and hygrometric movements were all found to be nicely related to one end-the aid of insects in fertilisation. Without their aid not a plant in the various species of twenty-nine genera which Darwin examined would set a seed. In the majority of cases insects withdraw the pollen masses only when retreating from the flower, and, continuing their flower visits, effect a union between two flowers, generally on distinct plants. In 
many cases the pollen masses slowly change their position while adhering to the insects, and so assume a proper direction for striking the stigma of another flower, and the insects during this interval will almost certainly have flown from one plant to another.

The family to which Catasetum belongs furnished the most remarkable examples. This plant possesses a special sensitiveness in certain parts, and when definite points of the flower are touched by an insect the pollen masses are shot forth like an arrow, the point being blunt and adhesive. The insect, disturbed by so sharp a blow, or having eaten its fill, flies sooner or later to a female plant, and whilst standing in the same position as before, the pollen-bearing end of the arrow is inserted into the stigmatic cavity, and a mass of pollen is left on its viscid surface. The strange structures of Cypripedium, or the Lady's Slipper, were then analysed, and the mode of fertilisation by small bees was discovered. The whole structure of orchids, as modified to secure insects' visits and cross fertilisation, was now expounded, and the benefits shown by cases where insects' visits were prevented, and no seed was set. The number of seeds in a capsule was reckoned, and thence it was found that the progeny of a single plant of the common orchis would suffice to cover the globe in the fourth generation. A single plant of another orchid might bear seventy-four millions of seeds: surely an ample provision for a struggle for existence, and selection and survival of the fittest. But, as Darwin remarks, profuse expenditure is nothing unusual in nature, and it appears to be more profitable for a plant to yield a few cross-fertilised than many self-fertilised seeds. 
Darwin impresses forcibly on his readers the endless diversity of structures, and the prodigality of resources displayed for gaining the same end, the fertilisation of one flower by pollen from another plant. "The more I study nature," he says, "the more I become impressed with ever-increasing force that the contrivances and beautiful adaptations slowly acquired through each part occasionally varying in a slight degree ... transcend in an incomparable manner the contrivances and adaptations which the most fertile imagination of man could invent." Finally he concludes: "It is hardly an exaggeration to say that nature tells us, in the most emphatic manner, that she abhors perpetual self-fertilisation"; and thus was announced a new doctrine in botany. A second muchimproved edition of this book appeared in 1877 .

In 1864 , in presenting the Copley medal of the Royal Society to the author of the "Origin of Species," MajorGeneral Sabine, the President, entered into a full description of the merits of his works, "stamped throughout with the impress of the closest attention to minute details and accuracy of observation, combined with large powers of generalisation." The award, while highly eulogising the "Origin," was not however based upon it, but on the more recent botanical writings. "The Fertilisation of Orchids" was described as perhaps the most masterly treatise on any branch of vegetable physiology that had ever appeared; and the fact was justly emphasised that all Darwin's botanical discoveries had been obtained by the study of some of the most familiar and conspicuous of our native plants, and some of the bestknown and easily-procured cultivated exotics. 
In 1865 appeared another work from the Darwinian treasury, but in this case it was at first restricted to the Journal of the Linnean Society (vol. ix.), and was not made generally available till the second edition was published separately in 1875 . "The Movements and Habits of Climbing Plants" described in the first place the twining of the hop plant, studied by night and day continuously, in a well-warmed room, to which the author was confined by illness. Again and again were different species of plants watched, and the periods in which their shoots revolved noted. The clematises, tropæolums, solanums, gloriosa lilies among leaf-climbing plants; the bignonias, cobæas, bryonies, vines, passion flowers, and other tendril-bearing plants; the ivy, and other root and hook climbers were carefully studied; and botanists for the first time realised fully the advantages which climbing plants possess in the struggle for existence. The climbing faculty depends on a sensitiveness to contact with any firm support, and a most interesting series of modifications has probably, as Darwin suggests, led to the present development of climbing organs, by the spontaneous movement of young shoots and other organs, and by unequal growth.

In concluding, the author made some most profoundly suggestive remarks, which went far to revolutionise our conception of plants. "It has often been vaguely asserted that plants are distinguished from animals by not having the power of movement. It should rather be said that plants acquire and display this power only when it is of some advantage to them; this being of comparatively rare occurrence, as they are affixed to the ground, 
and food is brought to them by the air and rain. We see how high in the scale of organisation a plant may rise, when we look at one of the more perfect tendrilbearers. It first places its tendrils ready for action, as a polypus places its tentacula. If the tendril be displaced, it is acted on by the force of gravity, and rights itself. It is acted on by the light, and bends towards or from it, or disregards it, which ever may be most advantageous. During several days the tendrils, or internodes, or both, spontaneously revolve with a steady motion. The tendril strikes some object, and quickly curls round and firmly grasps it. In the course of some hours it contracts into a spire, dragging up the stem, and forming an excellent spring. All movements now cease. By growth the tissues soon become wonderfully strong and durable. The tendril has done its work, and has done it in an admirable manner."

The labour of revising the successive editions of the "Origin of Species," together with prolonged ill-health, delayed the fulfilment of the promise given in that work, that the facts upon which it was based should be published. It was not till r 868 that the first instalment, "The Variation of Animals and Plants under Domestication," was given to the world, in two large volumes, with numerous illustrations. The author's design was to discuss in a second work the variability of organic beings in a state of nature, and the conversion of varieties into species, the struggle for existence and the operation of natural selection, and the principal objections to the theory, including questions of instinct and hybridisation. In a third work it was intended to test the principle of 
natural selection by the extent to which it explains the geological succession of organic beings, their distribution in past and present times, and their mutual affinities and homologies. The two latter works were never completed, in consequence of ill-health, and the labour involved in dealing with objections to and new facts in support of the "Origin," and of the other works which at various times it became important to complete. But many portions of these subjects were admirably dealt with by disciples. In some cases Darwin's views led to the rapid growth of a new science, such as that of comparative embryology, and it would not have been possible for him to cope with and interpret the multitude of new and astonishing facts discovered, which changed the face of organic nature as viewed by biologists. By doing each day the work which seemed most necessary, and which he could best do, Darwin managed, in spite of his infirmity of constitution, to complete a larger body of original work, both in experiment and in thought, together with a greater quantity of bibliographical study and collation of observed facts, than any Englishman perhaps has ever done.

The valuable book on "Variation" records and systematises a vast number of facts respecting all our principal domestic animals and cultivated plants. It gives evidence of wide reading, as well as great diligence in writing letters of inquiry to all living authorities who could give accurate information. Very many visits were paid to zoological gardens, breeders' establishments, nursery grounds, \&c.; and the preparation of skulls, skins, \&c., was a frequent occurrence in the Darwinianlaboratory. To take the case of rabbits alone, which 
occupied but a fraction of the time devoted to pigeons: over twenty works are quoted for historical facts, skeletons of various rabbits were prepared and exhaustively compared, the effects of use and disuse of parts traced, most careful measurements are given, and a list of the modifications which domestic rabbits have undergone, with the probable causes, concludes the chapter. As tc pigeons, no pigeon-fancier ought to be without the book, for never assuredly was a sporting topic treated by so great a thinker and so admirably. The numerous experiments in crossing different breeds, and the results obtained, make this one of the most instructive books for all breeders. It would seem desirable that this portion of the book should be issued in a separate form. Again, when we turn to the sections on plants we see how indefatigable Darwin was, for he tells us that he cultivated fifty-four varieties of gooseberries alone, and compared them throughout in flower and fruit.

The chapters on Inheritance, and on Reversion to ancestral characters, or atavism, are profoundly suggestive. What can be more wonderful, the author asks, than that some trifling peculiarity should be transmitted through a long course of development, and ultimately reappear in the offspring when mature or even when old? Nevertheless, the real subject of surprise is not that a character should be inherited, but that any should ever fail to be inherited. Gradually leading up to the important hypothesis with which the work closes, he observes that to adequately explain the numerous characters that reappear after intervals of one or more generations, we must believe that a vast number of characters, capable 
of evolution, lie hidden in every organic being. "The fertilised germ of one of the higher animals, subjected as it is to so vast a series of changes from the germinal cell to old age-incessantly agitated by what Quatrefages well calls the tourbillon vital-is perhaps the most wonderful object in nature. It is probable that hardly a change of any kind affects either parent, without some mark being left on the germ. But on the doctrine of reversion the germ becomes a far more marvellous object, for, besides the visible changes to which it is subjected, we must believe that it is crowded with invisible characters, proper to both sexes, to both the right and left side of the body, and to a long line of male and female ancestors separated by hundreds or even thousands of generations from the present time; and these characters, like those written on paper with invisible ink, all lie ready to be evolved under certain known or unknown conditions."

Through a further discussion of many deeply interesting facts about the intercrossing of breeds and species, and about the causes of variability, we pass to the hypothesis of pangenesis, which, briefly stated, supposes that the cells or units of the body are perpetually throwing off minute granules or gemmules, which accumulate in the reproductive system, and may, instead of developing in the next generation, be transmitted in a dormant state through more than one generation and then be developed. Combination in various degrees between these gemmules is supposed to influence their appearance or non-appearance in the offspring at various stages.

This hypothesis certainly gives a picture of a possible 
mode of accounting for many peculiarities shown by living organisms. Although not generally accepted, it has certainly not been disproved. Mr. Grant Allen's opinion that it is Darwin's "one conspicuous failure," and that it is "crude and essentially unphilosophic," must be discounted by his known devotion to $\mathrm{Mr}$. Herbert Spencer's philosophy. If Darwin had been a specialist in modern physiology, he might, perhaps, have expressed his hypothesis in a more persuasive form ; but Weismann's germ plasma theory is the only alternative one hitherto suggested in plare of it. 


\section{CHAPTER VII.}

$A$ LTHOUGH the descent of man from animal an1 cestors was directly implied in the "Origin of Species," Darwin hesitated at the time of its publication to declare his views fully, believing that he would only thus augment and concentrate the prejudice with which his theory would be met. He had for many years held the views he afterwards expressed; but it was not until he had by his other works raised up a strong body of scientific opinion in favour of his great generalisation, that he fully presented his views on man to the public. The "Descent of Man" was studied as a special case of the application of his general principles, a test all the more severe because several classes of argument were necessarily cut off, such as the nature of the affinities which connect together whole groups of organisms, their geographical distribution, and their geological succession. But adopting the high antiquity of man as demonstrated, he considered in detail the evidence as to man's descent from some preexisting form, the manner of his development, and the value of the differences between the so-called races of man. No originality is claimed for the theory or for the facts advanced; but it may safely be affirmed that 
the master's acuteness, his moderation, his candour, and his desire to state facts which tell against him, are as conspicuous in the "Descent of Man" as in any of his works.

The "Descent of Man," which was published in I87 I in two volumes, with numerous illustrations, began, after a short introduction, with a suggestive series of questions, which to the evolutionist suffice to decide the question as to man's origin. As the answers to these questions are obvious, Darwin first concentrated his inquiry upon two points on which disputes must necessarily occur, namely, the traces which man shows, in his bodily structure, of descent from some lower form, and the mental powers of man as compared with those of lower animals. The facts of our bodily structure are inexplicable on any other view than our community of descent with the quadrumana, unless structure is but a snare to delude our reason. It is only our natural prejudice, says Darwin, and that arrogance which made our fathers declare that they were descended from demigods, which leads us to demur to this conclusion.

The comparison of the mental powers of animals with those of man, proving, as Darwin contends, that they therein also show traces of community of descent, was certain to provoke much more debate, for the term "instinct" and the use made of it by naturalists and psychologists as signifying untaught, unlearnt ability, largely tended to obscure the question, and to create prejudices against believing that instincts could be built up by inherited experience, that instincts were really not absolute and fixed, but relative and variable, and that all instincts 
were not perfect or perfectly useful. The working out of the evolution theory as applied to animal minds, the study of the first beginnings of nerve action, and the analysis of instinct, all due largely to Darwin's prominent disciple, Romanes, together with the immensely fuller knowledge of molecular physics, of protoplasm, and of brain function, acquired in the years since Darwin wrote, have sufficed to place these questions on a much more secure basis. But the collection of facts made by him, and the suggestive remarks he everywhere makes, render his book of permanent value. His sympathy is obvious in such passages as this: "Every one has heard of the dog suffering under vivisection who licked the hand of the operator; this man, unless he had a heart of stone, must have felt remorse to the last hour of his life;" the "terrible" superstitions of the past, such as human sacrifices, trial by ordeal, \&c., show us, he says, "what an indefinite debt of gratitude we owe to the improvement of our reason, to science, and our accumulated knowledge." We see the fruit of Darwin's repeated visits to the Zoological Gardens, especially in his study of the habits and mental powers of monkeys. We gain a definition from him of imagination, by which faculty man " unites, independently of the will, former images and ideas, and thus creates brilliant and novel results. . . . The value of the products of our imagination depends of course on the number, accuracy, and clearness of our impressions; on our judgment and taste in selecting or rejecting the involuntary combinations, and to a certain extent on our power of voluntarily combining them.". As to religion, he says, "There is no evidence that man 
was aboriginally endowed with the ennobling belief in the existence of an omnipotent God." On the contrary, evidence proves that there are and have been numerous races without gods and without words to express the idea. The question, he says, is "wholly distinct from that higher one, whether there exists a Creator and Ruler of the universe ; and this has been answered in the affirmative by the highest intellects that have ever lived." The fact of races existing without a belief in a god is shown to be compatible with the origin of religious ideas from attempts to explain external phenomena and man's own existence, by attributing to other objects and agencies a similar spirit to that which his consciousness testifies to in himself,

Man's social qualities, as well as those of animals, Darwin regards as having been developed for the general good of the community, which he defines as "the means by which the greatest possible number of individuals can be reared in full vigour and health, with all their faculties perfect, under the conditions to which they are exposed." This may be regarded as a more satisfactory expression of the idea underlying the phrase, "the greatest happiness of the greatest number." Sympathy for animals he notes as one of the later acquisitions of mankind, and remarks that he found the very idea of humanity a novelty to the Gauchos of the Pampas. "The highest stage in moral culture at which we can arrive is when we recognise that we ought to control our thoughts. ... Whatever makes any bad action familiar to the mind, renders its performance so much the casier"- a significant expression for those 
who would compare the teachings of Darwinism with those of Christianity. Finally, he concludes that the difference in mind between man and the higher animals is one of degree, not of kind. "At what age does the new-born infant possess the power of abstraction, or become self-conscious and reflect on its own existence? We cannot answer; nor can we answer in regard to the ascending organic scale." Yet that man's mental and moral faculties may have been gradually evolved "ought not to be denied, when we daily see their development in every infant; and when we may trace a perfect gradation from the mind of an utter idiot, lower than that of the lowest animal, to the mind of a Newton."

The action of natural selection on the variations known to occur in man, is next shown to be sufficient to account for his rise from a lowly condition. Perhaps it is in discussing the development of the intellectual and moral faculties that Darwin is least successful; more knowledge of psychology than he possessed is demanded for this discussion. He gives up the problem of the first advance of savages towards civilisation as "at present much too difficult to be solved." $\mathrm{He}$, however, vigorously contests the idea that man was at first civilised and afterwards degenerated; and expresses the opinion that the "highest form of religion-the grand idea of God hating sin and loving righteousness-was unknown during primeval times." Finally, after discussing the steps in the genealogy of man, he comes to the conclusion that from the old-world monkeys, at a remote period, proceeded man, "the wonder and glory of the universe." The early progenitors of man he believes to 
have been covered with hair, both sexes having had beards; their ears were pointed and capable of movement; their bodies were provided with a tail, and the foot was probably prehensile. Our primitive ancestors lived chiefly in trees in some warm forest-clad land, and the males were provided with formidable weapons in the shape of great canine teeth.

"Thus," says Darwin, "we have given to man a pedigree of prodigious length, but not, it may be said, of noble quality. The world, it has been often remarked, appears as if it had long been preparing for the advent of man; and this, in one sense, is strictly true, for he owes his birth to a long line of progenitors. If any single link in this chain had never existed, man would not have been exactly what he now is. Unless we wilfully close our eyes, we may, with our present knowledge, approximately recognize our parentage; nor need we fecl ashamed of it. The most humble organism is something much higher than the inorganic dust under our feet; and no one with an unbiassed mind can study any living creature, however humble, without being struck with enthusiasm at its marvellous structure and properties."

In considering the formation and perpetuation of the races of mankind, Darwin was again and again baffled. He could not decide that any of the physical differences between the races are of direct and special service to him, thus giving opportunity to natural selection to work. Hence he was led to study in detail the effects of sexual selection, especially as applicable to man. The greater part of "The Descent of Man" is occupied with tracing out what may be called the history of courtship in man 
and animals. The great variety of interesting subjects dealt with cannot be detailed here. We must only notice a few points about mankind which are of special importance.

Darwin concludes that man's predominance over woman in size, strength, courage, pugnacity, and even energy was acquired in primeval times, and that these advantages have been subsequently augmented chiefly through the contests between men for women. Even man's intellectual vigour and inventiveness are probably due to natural selection, combined with inherited effects of habit, for the most able men will have succeeded best in defending and providing for their wives and offspring. Beards, beardlessness, voice, beauty are all related to sexual charm, and have been selectively developed. Early man, less licentious, not practising infanticide, was in several respects better calculated to carry out sexual selection than he is now; and thus we find the various races of men fully differentiated at the earliest date of historic records.

Incidentally Darwin gives us his views on the mental differences between man and woman. Woman is more tender and less selfish than man, whose ambition "passes too easily into selfishness," which latter qualities "seem to be his natural and unfortunate birthright." Woman's powers of intuition, of rapid perception, and perhaps of imitation, are more strongly marked than in man. Yet the chief pre-eminence of man he considers to consist in attaining greater success in any given line than woman, by reason of greater energy, patience, \&c. "In order that woman should reach the same standard as man, she 
ought, when nearly adult, to be trained to energy and perseverance, and to have her reason and iniagination exercised to the highest point, and then she would probably transmit these qualities chiefly to her adult daughters." Here we have a plan of women's higher education according to the great evolutionist, although he does not assert that it is the essential and desirable one; but given a certain object, here is the best method of securing it. "The whole body of women, however, could not be thus raised, unless during many generations the women who excelled in the above robust virtues were married, and produced offspring in larger numbers than other women."

The doctrine that man is descended from some less highly organised form, Darwin asserts in his concluding chapter, rests on grounds which will never be shakennamely, the similar structure and course of development of embryos of the higher animals, and vast numbers of facts of structure and constitution, rudimental structures, and abnormal reversions. The mental powers of the higher animals graduate into those of man. Language, and the use of tools, made man dominant. The brain then immensely developed, and morality sprang from the social instinct. Comparing and approving certain actions and disapproving others, remembering and looking back, he became conscientious and imaginative. Sympathy, arising in the desire to give aid to one's fellows, was strengthened by praise and blame, and conduces to happiness. "As happiness is an essential part of the general good, the greatest happiness principle indirectly serves as a nearly safe standard of right and wrong. . . . 
But with the less civilised nations reason often errs, and many bad customs and base superstitions come within the same scope, and consequently are esteemed as high virtues and their breach as heavy crimes."

The belief in God, the author says, is not innate or intuitive in man, but only arises after long culture. As to the bearing of the evolution theory on the immortality of the soul, Darwin thinks few people will find cause for anxiety in the impossibility of determining at what period in the ascending scale man became an immortal being. "The birth, both of the species and of the individual, are equally parts of that grand sequence of events, which our minds refuse to accept as the result of blind chance. The understanding revolts at such a conclusion."

The bearing of the Darwinian doctrine on some important practical questions for society leads to the remark that, while man scans with scrupulous care the pedigree of his animals, when he comes to his own marriage he rarely or never takes any such care. Perhaps Darwin was somewhat in error here; and, also, he seems to have underrated the unconscious tendency to act according to natural law, which has no doubt influenced mankind largely. He lays down the principle that both sexes ought to refrain from marriage if markedly inferior in body or mind, or if they cannot avoid abject poverty for their children. When the laws of inheritance are thoroughly known, he says, we shall not hear ignorant members of our legislature rejecting with scorn a plan for ascertaining, by an easy method, whether or not consanguineous marriages are injurious to man. But Darwin is by no means in favour of any restriction on man's 
natural rate of increase; for it is the greatest means of preventing indolence from causing the race to become stagnant or to degenerate. Only, there should be open competition for all men; and the most able should not be prevented by laws or customs from succeeding best and rearing the largest number of offspring.

In summing up on the entire subject, Darwin expresses himself with more than his wonted vigour and point. On the one hand, he endeavours to disarm opposition by quoting heroic monkeys as contrasted with degraded barbarians; on the other hand, he welcomes the elevation of man so far above his barbarous ancestors. Finally, he takes his stand upon truth, as against likes and dislikes. "The astonishment which I felt on first seeing a party of Fuegians on a wild and broken shore will never be forgotten by me, for the reflection at once rushed into my mind-such were our ancestors. These men were absolutely naked and bedaubed with paint; their long hair was tangled, their mouths frothed with excitement, and their expression was wild, startled, and distrustful. They possessed hardly any arts, and, like wild animals, lived on what they could catch. They had no government, and were merciless to every one not of their own small tribe. He who has seen a savage in his native land will not feel much shame, if forced to acknowledge that the blood of some more humble creature flows in his veins. For my own part, I would as soon be descended from that heroic little monkey, who braved his dreaded enemy in order to save the life of his keeper; or from that old baboon, who, descending from the mountains, carried away in triumph his young comrade 
from a crowd of astonished dogs - as from a savage who delights to torture his enemies, offers up bloody sacrifices, practises infanticide without remorse, treats his wives like slaves, knows no decency, and is haunted by the grossest superstitions.

"Man maybe excused for feeling some pride at having risen, though not through his own exertions, to the very summit of the organic scale; and the fact of his having thus risen, instead of having been aboriginally placed there, may give him hopes for a still higher destiny in the distant future. But we are not here concerned with hopes or fears, only with the truth as far as our reason allows us to discover it. I have given the evidence to the best of my ability; and we must acknowledge, as it seems to me, that man, with all his noble qualities, with sympathy which feels for the most debased, with benevolence which extends not only to other men, but to the humblest living creature, with his god-like intellect which has penetrated into the movements and constitution of the solar system-with all these exalted powers-Man still bears in his bodily frame the indelible stamp of his lowly origin."

The reception accorded to "The Descent of Man" was more excited than that of "The Origin of Species." The first large edition was quickly exhausted, and discussion or ridicule of the book was the fashionable recreation. Mr. Punch, week after week, reflected passing opinion. One of his Darwinian ballads on our ancestors is worth quoting from :-

\footnotetext{
"They slept in a wood, Or wherever they could,
} 
For they didn't know how to make beds;

They hadn't got huts,

They dined upon nuts,

Which they cracked upon each other's heads.

They hadn't much scope

For a comb, brush, or soap,

Or towels, or kettle, or fire ;

They had no coats nor capes,

For ne'er did these apes

Invent what they didn't require.

From these though descenderl,

Our manners are mended,

Though still we can grin and backibite;

We cut up each other,

Be he friend or brother,

And tails are the fashion-at night.

This origination

Is all speculation-

We gamble in various shapes;

So Mr. Darwin

May speculate in

Our ancestors having been apes."

The Athenaum was unbelieving, but not denunciatory. The Edinburgh Review declared the doctrine of natural selection hopelessly inadequate to explain the phenomena of man's body; although its truth and falsehood had no necessary connection with the general theory of evolution: some law as yet unknown being looked for. Darwin's attempt to explain the evolution of mind and the moral sense is regarded as failing in every point. "Never, perhaps, in the history of philosophy, have such wide generalisations been derived from such a small basis of fact." The Quarterly Revieze now acknowledged that 
"the survival of the fittest" was a truth which readily presented itself to any one considering the subject, and that to Darwin was due the credit of having first brought it forward and demonstrated its truth, and asserted that the destruction of the least fit was recognised thousands of years ago. But, in regard to the descent of man, it fastens specially upon the author's theory of mental and moral evolution, and declares that he has utterly failed. The Saturday Review, however, admitted the high antiquity of man, and the nearness of his bodily structure to the apes, and went much further. In discussing the evolution of morals, the author's unexampled grasp of facts, with his power of correlation, is, according to The Saturday, seen at its highest, in an exquisite chain of philosophical deduction. The mode in which, at a remote period, the races of mankind became differentiated, is declared to be the weak point in the argument. 


\section{CHAPTER VIII.}

"THE Expression of the Emotions in Man and 1 Animals" followed "The Descent of Man" in I872. The motive which suggested it was the desire to explain the complexities of expression on evolution principles. But the study of emotional expression had evidently engaged Darwin's attention at least from the time when the Fuegians and the Gauchos had vividly roused his imaginative faculties; and his direct observations commenced as early as 1838 , when he was already inclined to believe in evolution, and were continued at intervals ever after. The third edition of Sir Charles Bell's "Anatomy of Expression," published in I844, while greatly admired by him, was unsatisfactory in being throughout based on the conviction that species came into existence in their present condition; and notwithstanding that Bain and Herbert Spencer had made considerable advances in a treatment of the subject based on physiology, an exhaustive book was wanted, which should throw on Expression the new and interesting light of Darwinism.

What was Darwin's method? Observation, cleverly 
devised appeal to nature; observation over a wide field as to the varied races of man still existing, utilising the aid of travellers and residents in many lands ; observation of domestic animals in familiar and in untried circumstances; observation of infants, especially his own, from a very early age; observation of the insane, who are liable to the strongest passions, and give them uncontrolled vent. It was in 1867 that Darwin circulated his group of questions designed to ascertain the mode of expressing every emotion, and their physical concomitants in every possible race. Sculpture, paintings, and engravings, afforded little evidence, because beauty is their main object, and "strongly contracted facial muscles destroy beauty." Information was specially sought as to natives who had had little communication with Europeans, and in whom imitation might not have destroyed ancestral and original expression.

The result was to develop three principles which appeared, in combination, to account for most of the expressions and gestures involuntarily used by man and animals. The first was that of serviceable associated habits : certain complex actions being somehow serviceable in particular states of mind, to gratify and relieve certain sensations, desires, \&c., whenever the same state of feeling is repeated, there is a tendency to the same movements or actions, though they may not then be of the least use. The second principle, that of antithesis, is the converse of the last; when an opposite state of mind is induced, there is an involuntary tendency to directly opposite movements, though of no use. The third principle, that of the direct action of the nervous 
system, is independent of the will and of habit; nerve force being generated in excess by strong emotions.

In discussing all these principles we discover how every thought and every circumstance of the great naturalist seem to have been utilised in his life work. "I have noticed that persons in describing a horrid sight, often shut their eyes momentarily and firmly, or shake their heads as if not to see, or to drive away, something disagreeable; and I have caught myself, when thinking in the dark of a horrid spectacle, closing my eyes firmly." "I noticed a young lady earnestly trying to recollect a painter's name, and she first looked to one corner of the ceiling, and then to the opposite corner, arching the one eyebrow on that side, although of course there was nothing to be seen there." "Many years ago I laid a small wager with a dozen young men that they would not sneeze if they took snuff, although they all declared that they invariably did so; accordingly they all took a pinch, but from wishing much to succeed, not one sneezed, though their eyes watered, and all, without exception, had to pay me the wager." "I put my face close to the thick glass-plate in front of a puff-adder in the Zoological Gardens, with the firm determination of not starting back if the snake struck at me; but as soon as the blow was struck, my resolution went for nothing, and I jumped a yard or two backwards with astonishing rapidity. My will and reason were powerless against the imagination of a danger which had never been experienced." "I observed that though my infants started at sudden sounds, when under a fortnight old, they certainly did not always wink their eyes, and I believe never did so. 
The start of an older infant apparently represents a vague calching hold of something to prevent falling. I shook a pasteboard box close before the eyes of one of my infants, when Ir4 days old, and it did not in the least wink; but when I put a few comfits into the box, holding it in the same position as before, and rattled them, the child blinked its eyes violently every time, and started a little." The behaviour of dogs and horses under many circumstances was watched. Cats and monkeys were most carefully scrutinised. At all moments Darwin seized upon and recorded the passing emotion and its associated movements. "I remember once seeing a boy who had just shot his first snipe on the wing, and his hands trembled to such a degree from delight, that he could not for some time reload his gun;" an instance of an emotional movement being disadvantageous.

Some of Darwin's descriptions of emotional outbursts are among the best portions of his writing; as when he speaks of a mother whose infant has been intentionally injured, "how she starts up with threatening aspect, how her eyes sparkle and her face reddens, how her bosom heaves, nostrils dilate, and heart beats." In describing a mourner when quiescent, he says: "The sufferer sits motionless, or gently rocks to and fro; the circulation becomes languid; respiration is almost forgotten, and deep sighs are drawn. All this reacts on the brain, and prostration soon follows with collapsed muscles and dulled eyes."

One of the most striking features of this book is the evidence it affords of Darwin's acuteness and persistence in observation during his travels, and of the excellence of 
his memory. "I remember that my mules and dogs, brought from a lower and warmer country, after spending a night on the bleak Cordillera, had the hair all over their bodies as erect as under the greatest terror." $\mathrm{He}$ noted that Jemmy Button, the Fuegian, blushed when he was quizzed about the care which he took in polishing his shoes, and in otherwise adorning himself; and this fact long after is fitted into the theory of blushing. Guanacoes in South America, when not intending to bite, but merely to spit their offensive saliva from a distance at an intruder, yet retract their ears as a sign of their anger; and Darwin found the hides of several which he shot in Patagonia, deeply scored by teeth marks, in consequence of their battles with each other. A party of natives in Tierra del Fuego endeavoured to explain that their friend, the captain of a sealing vessel, was out of spirits, by pulling down their cheeks with both hands, so as to make their faces as long as possible; and the fact is treasured till it comes in to illustrate the lengthening of features under depression. As if he foreknew that he should want the fact forty years later, he inquired of Jemmy Button whether kissing was practised by his people, and learnt that it was unknown to them. "I remember," he says, "being struck whilst travelling in parts of South America, which were dangerous from the presence of Indians, how incessantly-yet as it appeared, unconsciously-the half-wild Gauchos closely scanned the whole horizon." "In Tierra del Fuego, a native touched with his finger some cold preserved meat which I was eating at our bivouac, and plainly showed utter disgust at its softness; whilst I felt utter disgust at my 
food being touched by a naked savage, though his hands did not appear dirty." And this illustrates the primary meaning of disgust-anything offensive to the taste.

In later years his own children, and his domestic pets, were incessantly watched, and suitable experiments were devised to bring out the real nature of their expressions. The period at which tears are formed and crying begins, the shape of the mouth in crying, the contraction of the muscles in shouting, the effects of steady gazing at objects, the various stages of smiling, the effects of shyness, shame, and fear, are all set before us, as thus observed. For instance, "I asked one of my boys to shout as loudly as he possibly could, and as soon as he began he firmly contracted his orbicular muscles (surrounding the eyes). I observed this repeatedly, and on asking him why he had every time so firmly closed his eyes, I found that he was quite unaware of the fact : he had acted instinctively or unconsciously." Some of his early observations were afterwards published by Darwin in Mind, vol. ii., under the title of "A Biographical Sketch of an Infant."

Here is a carefully-worded and very suggestive experiment on animals : "Many years ago, in the Zoological Gardens, I placed a looking-glass on the floor before two young orangs, who, as far as it was known, had never before seen one. At first they gazed at their own images with the most steady surprise, and often changed their point of view. They then approached close, and protruded their lips towards the image, as if to kiss it, in exactly the same manner as they had previously done towards each other when first placed, a few days before, in the same room. They next made all sorts of grimaces, and 
put themselves in various attitudes before the mirror; they pressed and rubbed the surface; they placed their hands at different distances behind it ; looked behind it ; and finally seemed almost frightened, started a little, became cross, and refused to look any longer." So monkeys were tested with a dressed doll, a live turtle, and stuffed snakes, \&c.

The mode and purpose of erection of the hair, feathers, and dermal appendages of animals were the subject of much careful inquiry. Chimpanzees, monkeys, baboons, and many other creatures, were tested in the Zoological Gardens. A stuffed snake taken into the monkcy-house caused several species to bristle. When Darwin showed the same to a peccary, the hair rose in a wonderful manner along its back. A cassowary erected its feathers at sight of an ant-eater.

Every unexpected occurrence was pressed into service. Witness the following anecdote: "One day my horse was much frightened at a drilling machine, covered by a tarpaulin and lying on an open field. He raised his head so high that his neck became almost perpendicular; and this he did from habit, for the machine lay on a slope below, and could not have been seen with more distinct ness through the raising of the head; nor if any sound had proceeded from it could the sound have been more distinctly heard. His eyes and ears were directed intently forwards; and I could feel through the saddle the palpitations of his heart. With red, dilated nostrils, he snorted violently, and whirling round, would have dashed off at full speed had I not prevented him."

We see, too, in this book the results of Darwin's 
extensive reading. The novelists are laid considerably under contribution, their power of describing expressive signs of emotion being particularly appreciated. Dickens, Walter Scott, Mrs. Oliphant, and Mrs. Gaskell are among the novelists quoted; while the author of Job, Homer, Virgil, Seneca, Shakespeare, Lessing, Sir Joshua Reynolds, and many other deceased writers, illustrate the subject. The living authorities-scientific men, travellers, doctors-referred to for facts are exceedingly numerous, including Sir James Paget, Professor Huxley, Mr. Herbert Spencer, Sir J. Crichton Browne, Sir Samuel Baker, Sir Joseph Lister, Professors Cope and Asa Gray, and many others.

One of the most interesting chapters in the book is that dealing with blushing. It is shown to depend on self-attention, excited almost exclusively by the opinion of others. "Every one feels blame more acutely than praise. Now, whenever we know, or suppose, that others are depreciating our personal appearance, our attention is strongly drawn towards ourselves, more especially to our faces." This excites the nerve centres receiving sensory nerve for the face, and in turn relaxes the blood capillaries, and fills them with blood. "We can understand why the young are much more affected than the old, and women more than men, and why the opposite sexes especially excite each others' blushes. It becomes obvious why personal remarks should be particularly liable to cause blushing, and why the most powerful of all the causes is shyness; for shyness relates to the presence and opinion of others, and the shy are always more or less self-conscious." 
One great result made clear by Darwin is that the muscles of expression have not been created or developed for the sake of expression only, and that every true or inherited movement of expression had some natural or independent origin. All the chief expressions are proved to be essentially the same throughout the world, which is an additional argument for man being descended from one stock. We cannot refrain from admiring the tone of the pages which close the book, describing as they do the probable expressions of our early ancestors, their utility, the value of differences of physiognomy, and the desirability or otherwise of repressing signs of emotion. The subject, says the author, "deserves still further attention, especially from any able physiologist;" and so simply ends a volume of surpassing human interest, a text-book for novelists and students of human nature, a landmark in man's progress in obedience to the behest "Know thyself."

To fully measure the merit of one so far elevated above ordinary men is almost impossible; rather is it desirable to recognise the undeniable greatness of a great man, and learn all that is possible from him. An undoubted authority in mental science, however, has given a judgment on Darwin's services to that science, which it is right to quote: "To ourselves it almost seems one of the most wonderful of the many wonderful aspects of Mr. Darwin's varied work that by the sheer force of some exalted kind of common-sense, unassisted by any special acquaintance with psychological method, he should have been able to strike, as it were, straight down upon some of the most important truths which have ever been 
brought to light in the region of mental science." I These truths are specified as the influence of natural selection in the formation of instinct, in the "Origin of Species;" the evolution of mind and of morals, in the "Descent of Man," considered by the late Professor Clifford as containing the simplest and clearest and most profound philosophy that was ever written on the subject; and the evolution of expression in the book described in this chapter. Thus, says Mr. Romanes, in respect both of instincts and intelligence, the science of comparative psychology may be said to owe its foundation to Darwin.

"G. J. Romanes, in "Charles Darwin," memorial notices reprinted from Nature. 


\section{CHAPTER IX.}

T $N 875$ appeared ariother great work from the master's 1 pen, "Insectivorous Plants," which was destined to place in a yet more striking light the many-sidedness and fertility of his mind. As usual Darwin tells us that this work dated from many years back. "During the summer of I860," he says, "I was surprised by finding how large a number of insects were caught by the leaves of the common sun-dew (Drosera rotundifolia) on a heath in Sussex. I had heard that insects were thus caught, but knew nothing further on the subject. I gathered by chance a dozen plants, bearing fifty-six fully expanded leaves, and on thirty-one of these dead insects or remnants of them adhered." Here was the germ of something, the discoverer scarcely knew what. It was evident to him that the little sun-dew was excellently adapted for catching insects, and that the number of them thus slaughtered annually must be enormous. What bearing might this have upon the problem of the struggle for existence?

A masterly series of experiments was forthwith set on foot, with the result of proving that sun-dews and a number of other plants obtain the bulk of their nourish- 
ment by catching, killing, and digesting insects. They may be called truly carnivorous plants. What an unexpected reversal this was of the order of things hitherto believed to prevail universally. Animals live on other animals or on plants. Here were plants living on animals, and keeping down their number. Moreover, without a nervous system, the action of the parts of a sun-dew leaf was proved to be as apparently purposive as the combined action of the limbs of an animal. Without a stomach, the sun-dew poured forth a digestive fluid as effective in extracting and fitting the nutritious matter of the insect for its own purposes as that of an animal. Without sensory nerve-endings, there was a percipient power in the sun-dew which recognised instinctively and at once the non-nutritious nature of various objects, and which responded to the most delicate chemical stimuli and to the minutest weights.

We cannot describe the little sun-dew better than in Darwin's own words: "It bears from two or three to five or six leaves, generally extended more or less horizontally, but sometimes standing vertically upwards. The leaves are commonly a little broader than long. The whole upper surface is covered with gland-bearing filaments, or tentacles as I shall call them from their manner of acting. The glands were counted on thirty-one leaves, but many of these were of unusually large size, and the average number was 192 ; the greatest number being 260 , and the least $\mathrm{r} 30$. The glands are each surrounded by large drops of extremely viscid secretion, which, glittering in the sun, have given rise to the plant's poetical. name of the sun-dew." 
This secretion, when excited by nutritious matter, becomes distinctly acid, and contains a digestive ferment allied to the pepsin of the human stomach. So excited, it is found capable of dissolving boiled white of egg, muscle, fibrin, cartilage, gelatine, curd of milk, and many other substances. Further, various substances that animal gastric juice is unable to digest are not acted upon by the secretion of the sun-dew. These include all horny matter, starch, fat, and oil. It is not however prejudiced in favour of animal matter. The sun-dew can absorb nutriment from living seeds of plants, injuring or killing them, of course, in the process, while pollen and fresh green leaves yield to its influence.

The action of salts of ammonia and other chemicals was even more wonderful. "It is an astonishing fact that so inconceivably minute a quantity as the one twentymillionth of a grain of phosphate of ammonia should induce some change in a gland of Drosera sufficient to cause a motor impulse to be sent down the whole length of the tentacle; this impulse exciting movement often through an angle of above $180^{\circ}$. I know not whether to be most astonished at this fact, or that the pressure of a minute bit of hair, weighing only $\overline{7} \frac{1}{70} \overline{0}$ of a grain, and largely supported by the dense secretion, should quickly cause conspicuous movement."

These are but specimens of a multitude of profoundly interesting facts brought out in this exhaustive investigation. If this single research were his only title to fame Larwin's name must rank high as an experimenter of rare ingenuity and success. But he concludes his summary of results by the utterly modest remark, "We see how 
little has been made out in comparison with what remains unexplained and unknown."

The facts relating to Venus' fly-trap (Dionca muscipula) and other members of the order to which the sun-dew belongs were better known, but Darwin elicited new truths by his ingenious and varied experiments. The rapidity with which the two lobes of the leaf of dionæa close together when anything touches the tiny spikes which stand up vertically from the upper surface of the lobes, is astonishing, and any insect which causes the closure is almost certain to be caught. Digestion is accomplished in the case of the dionæa by a separate agency, consisting of a large number of minute reddish glands covering the surface of the lobes. These secrete a digestive fluid when stimulated by the contact of any nitrogenous matter, and of course this takes place when any insect is caught. In fact, essentially the same process of digestion and absorption takes place as in the sun-dew. The insect is held firmly for days, until its juices have been absorbed, and then the leaf slowly reopens, not being able to close again for many subsequent days.

It is interesting to note the extreme caution with which the great naturalist speculates upon the mode by which the varied members of the sun-dew order became modified from an ordinary plant-form to such a remarkable degree. The details are too special for quotation here. He suggests, but he does not in the slightest degree dogmatise. For many years to come Darwin's suggestions and comments must be the pregnant soil out of which fruitful research will spring, and his caution will remain 
the model, to depart from which will but sow hindrances in the path of scientific progress.

The order to which the butterwort and the bladderworts belong also afforded valuable results. The leaf of the butterwort bears glandular hairs, and its margins curve inwards when excited by contact of various bodies, especially living insects, and, at the same time, these are caught in the viscid secretion of the glands, and their juices absorbed by the plant. The bladderworts are even more remarkably constructed, for they have a portion of their leaves developed into subaqueous bladders, with a narrow entrance beneath, defended by a complex valve, which facilitates the entrance of water insects or crustaceans, but prevents their exit. The whole interior of the bladder is lined with transparent fourbranched protoplasmic hairs, but nevertheless the bladderwort is unlike the preceding plants in having no power of digesting its prey, however long it may remain in captivity. Yet there is no doubt that the imprisoned creatures do decay in their watery cell, and that the hairs just described absorb the products of their decay.

Such is a brief account of Darwin's work on "Insectivorous Plants." With his characteristic expressions he acknowledges the valuable aid given him by Professor Burdon-Sanderson, and by his son, Mr. Francis Darwin. The former was enabled to give the first brief account of the process of digestion in these plants, as observed by Darwin, in a lecture before the Royal Institution, in June, 1874, and Dr. (now Sir Joseph) Hooker called general public notice to the subject of Carnivorous Plants in his lecture before the British Association at 
Belfast in the same year: so that a thoroughly awakened attention was given to this new work from Darwin's pen. The public and the scientific world learnt to appreciate yet more keenly his varied talent, his long patience, his reserve of power; and thence dated very definitely a general appreciation of the fundamental unity of the animal and plant kingdoms, seeing that the salient faculties of digestion, of purposive locomotion, of rapid communication and consentancous action were no longer restricted to animals, but were possessed in a high degree by plants also. Eager followers soon brought forward further proofs of unity of functions in the two kingdoms, and of reciprocal combinations between them, and now no one in the slightest degree acquainted with modern biology doubts that life is at bottom one phenomenon, shared equally and manifested in essentially the same modes by the living substance of plant and animal alike.

Following "Insectivorous Plants" came "The Effects of Cross and Self-Fertilisation in the Vegetable Kingdom," in 1876 . Darwin had led the way in the study of this subject by his book on Orchids, and his lead had been excellently followed by Hildebrand, Hermann Müller, Sir John Lubbock, and others. The path having been indicated, it had appeared comparatively easy for botanists to follow it up. But there yet remained a region of experimental inquiry which it required Darwin's patience and ingenuity to master and to expound conclusively. Although it might be practically granted that natural selection developed a process because advantage was gained by it, was it possible to demonstrate that 
flowers cross-fertilised bear more and larger seeds, which produce healthier offspring than those fertilised from their own pollen? This Darwin set himself exhaustively to do. For more than a dozen years after his book on orchids appeared, unwearied experiments on plants were progressing, and nature was being questioned acutely, untiringly. Competitive germination was carried on. The two classes of seeds were placed on damp sand in a warm room. As often as a pair germinated at the same time, they were planted on opposite sides of the same pot, with a partition between. Besides these pairs of competitors, others were planted in beds, so that the descendants of the crossed and self-fertilised flowers might compete. The resulting seeds were carefully compared, and their produce again compared. Species were selected from widely distinct families, inhabiting various countries. From a large number of plants, when insects were quite excluded by a thin net covering the plant, few or no seeds were produced. The extent of transport of pollen by insects was unveiled, and the relation between the structure, odour, and conspicuousness of flowers, the visits of insects, and the advantages of cross-fertilisation was shown. "We certainly," says Darwin, "owe the beauty and odour of our flowers, and the storage of a large supply of honey, to the existence of insects." The multitude of facts gathered about insects could only have been discovered and rightly appreciated by one who was a true entomologist as well as a botanist.

In the last chapter of the book the author discusses with remarkable power the causes of the phenomena he 
has discovered. He believes that the favourable effects of crossing are due to the parents having been subjected to diverse conditions; but what the precise benefit is, or how it can operate so as to render the offspring more healthy and vigorous, he cannot discern. "And so it is," he observes, "with many other facts, which are so obscure that we stand in awe before the mystery of life." So it is. The man who probably understood nature better than any man who has ever lived, who had not only asked her multitudinous questions, but to whom very many answers had been undoubtedly vouchsafed in response to his persevering, humble, diligent, acute questioning, acknowledges that he knows little; that much remains a mystery. But from all we know of him, from his books, his letters, his friends, his was the joy of a soul in sympathy with the master power of the universe. He marched continually on the confines of the unknown, and to him was granted the felicity of largely extending the boundaries of the known.

Again, in 1877 , a new work proceeded from Darwin's pen, "The Different Forms of Flowers in Plants of the same Species," dedicated to Professor Asa Gray. It gathered up the contents of numerous papers read before the Linnean Society, with later additions, and showed conclusively how many plants possess distinctive forms of flowers in the same species, adapted to, and in some cases absolutely necessitating, reciprocal fertilisation through the visits of insects. It gave evidence of all the well-known Darwinian characteristics of long-continued labour, thought, and experiment.

In I880 "The Power of Movement in Plants" was ex- 
emplified in a fresh volume, in which the veteran was materially assisted by his son, Mr. Francis Darwin. Its object was to describe and connect together several large classes of movements, common to almost all plants. The surprising fact was established, that all the parts or organs of plants, whilst they continue to grow, are continually revolving, or circumnutating as Darwin called it. This movement commences even before the young seedling has broken through the ground. The combination of this with the effects of gravity and light explains countless phenomena in the life of plants. . The tip of the rootlet is thus enabled to penetrate the ground, and it is proved to be more sensitive than the most delicate tendril. Movement goes on through all stages of life. Every growing shoot of a great tree is continually describing small ellipses; the tip of every rootlet endeavours to do the same. The changes of position of leaves and of climbing plants, and the sleep of leaves are all brought under this great principle of circumnutation. It is impossible in reading the book not to be struck with the great resemblance between the movements of plants and many of the actions performed unconsciously by the lower animals. "With plants an astonishingly small stimulus suffices, and, even with allied plants, one may be highly sensitive to the slightest continued pressure, and another highly sensitive to a slight momentary touch. The habit of moving at certain periods is inherited both by plants and animals, and several other points of similitude have been specified. But the most striking resemblance is the localisation of their sensitiveness, and the transmission of an influence from the excited part to another which consequently moves. Yet plants do not 
of course possess nerves. or a central nervous system; and we may infer that with animals such structures serve only for the more perfect transmission of impressions, and for the more complete intercommunication of the several parts."

Here we see how much light may be thrown on animal structures and functions by vegetable physiology. We learn to limit our ideas of the superiority of animals by discovering how much of what we consider peculiar to them is found in plants. IVe appreciate the unity of biology, indivisible without injury to our knowledge of its parts. No structure in plants appears more wonderful, as Darwin describes it, than the tip of the rootlet of a seedling. It is impressed by and transmits influences of pressure, injury, moisture, light, and gravity to other parts, and determines the course pursued by the rootlet in penetrating the ground. "It is hardly an exaggeration to say that the tip of the radicle thus endowed, and having the power of directing the movements of the adjoining parts, acts like the brain of one of the lower animals;" and the brain of Charles Darwin, in working out this acquisition of knowledge for mankind, has added a new department to vegetable physiology and to biology. 


\section{CHAPTER X.}

$\mathrm{T}$ his later years honours poured thick upon Darwin. 1 In 187 r he received the Prussian order of knighthood "For Merit"; and was elected a corresponding member of the Austrian Academy of Sciences. In I 877 Cambridge University, making an exception to its custom of not conferring honorary degrees on its members, gave him the LL.D. and an ovation, when the kindly eyes of the venerable naturalist beamed upon the monkey-figure dangled by undergraduates before him from the galleries, in addition to a solitary link of a huge chain, no doubt representing "the missing link." In 1878 the honour, long withheld, and certainly unsought, of being elected a corresponding member of the Paris Academy of Sciences in the section of Zoology, was his; and that tardy body recognised late the man whose supremacy in science it had done nothing either to foster or to approve. In I 879 the Baly Medal of the London College of Physicians was awarded to him.

After the Cambridge celebration a subscription was raised to obtain a portrait of the veteran evolutionist, which was executed by Mr. W. B. Richmond, and now adorns the Philosophical Library of the New Museums at Cambridge. Later, yet another portrait-the finest 
in his own and many others' belief-was painted by $\mathrm{Mr}$. John Collier, and presented to the Linnean Society, which will always be associated with the first announcement of Darwin's main theory, as well as with many others of his scientific discoveries.

Professor Haeckel has given the following charming description of Darwin and his home surroundings in his later years: "In Darwin's own carriage, which he had thoughtfully sent for my convenience to the railway station, I drove, one sunny morning in October, through the graceful, hilly landscape of Kent, that with the chequered foliage of its woods, with its stretches of purple heath, yellow broom, and evergreen oaks, was arrayed in its fairest autumnal dress. As the carriage drew up in front of Darwin's pleasant country house, clad in a vesture of ivy and embowered in elms, there stepped out to meet me from the shady porch, overgrown with creeping plants, the great naturalist himself, a tall and venerable figure, with the broad shoulders of an Atlas supporting a world of thought, his Jupiter-like forehead highly and broadly arched, as in the case of Goethe, and deeply furrowed with the plough of mental labour; his kindly, mild eyes looking forth under the shadow of prominent brows; his amiable mouth surrounded by a copious silver-white beard. The cordial, prepossessing expression of the whole face, the gentle, mild voice, the slow, deliberate utterance, the natural and naive train of ideas which marked his conversation, captivated my whole heart in the first hour of our meeting, just as his great work had formerly, on my first reading it, taken my whole understanding by storm. I 
fancied a lofty world-sage out of Hellenic antiquity-a Socrates or Aristotle-stood before me."

The well-known botanist, Alphonse de Candolle, thus describes a visit to Down:

"I longed to converse once more with Darwin, whom I had seen in I839, and with whom I kept up a most interesting correspondence. It was on a fine autumn morning in $\mathrm{I} 880$ that $\mathrm{I}$ arrived at Orpington station, where my illustrious friend's break met me. I will not here speak of the kind reception given to me at Down, and of the pleasure I felt in chatting familiarly with Mr. and Mrs. Darwin and their son Francis. I note only that Darwin at seventy was more animated and appeared happier than when I had seen him forty-one years before. His eye was bright and his expression cheerful, whilst his photographs show rather the shape of his head, like that of an ancient philosopher. His varied, frank, gracious conversation, entirely that of a gentleman, reminded me of that of Oxford and Cambridge savants. The general tone was like his books, as is the case with sincere men, devoid of every trace of charlatanism. He expressed himself in English easily understood by a foreigner, more like that of Bulwer or Macaulay, than that of Dickens or Carlyle. I asked him for news of the committee, of which he was a member, for reforming English spelling, and when I said that moderate changes would be best received by the public, he laughingly said, 'As for myself, of course, I am for the most radical changes.' We were more in accord on another point, that a man of science, even 
up to advanced age, ought to take an interest in new ideas, and to accept them, if he finds them true. 'That was very strongly the opinion of my friend Lyell,' he said; 'but he pushed it so far as sometimes to yield to the first objection, and I was then obliged to defend him against himself.' Darwin had more firmness in his opinions, whether from temperament, or because he had published nothing without prolonged reflection.

"Around the house no trace appeared to remain of the former labours of the owner. Darwin used simple means. He was not one who would have demanded to have palaces built in order to accommodate laboratories. I looked for the greenhouse in which such beautiful experiments on hybrid plants had been made. It contained only a vine. One thing struck me, although it is not rare in England, where animals are loved. A heifer and a colt were feeding close to us with the tranquillity which tells of good masters, and I heard the joyful barking of dogs. 'Truly,' I said to myself, 'the history of the variations of animals was written here, and observations must be going on, for Darwin is never idle.' I did not suspect that I was walking above the dwellings of those lowly beings called earthworms, the subject of his last work, in which Darwin showed once more how little causes in the long run produce great effects. He had been studying them for thirty years, but I did not know it.

"Returning to the house, Darwin showed me his library, a large room on the ground floor, very convenient for a studious man; many books on the shelves; windows on two sides; a writing-table and another for apparatus 
for his experiments. Those on the movements of stems and roots were still in progress. The hours passed like minutes. I had to leave. Precious memories of that visit remain."

Yet once more, in $\mathrm{x} 88 \mathrm{I}$, the famous publishing house of Murray issued a new work-his last-by the great illuminator of Nature. Its subject was one which no one save those who knew him could have expected. It dealt with "The Formation of Vegetable Mould, through the Action of Worms, with Observations on their Habits," and in it the lowly earthworm was at last raised to its true rank as the genuine preparer and possessor of the soil. Both Gilbert White and Edward Jenner had been impressed with the work earthworms do in nature, but no one had written extensively on the subject till Darwin himself, in 1837 , read a short paper on the "Formation of Mould" before the Geological Society of London (published in the fifth volume of the Society's Transactions), showing that small fragments of burnt marl, cinders, \&c., which had been thickly strewed over the surface of several meadows, were found after a few years lying at the depth of some inches beneath the turf. It was suggested to him by his relative Mr. Wedgwood, of Maer Hall, in Staffordshire, that this was due to the quantity of fine earth continually brought up to the surface by worms in the form of castings. Observation and experiment were to settle the question in the usual Darwinian manner, and many a portion of soil was watched. One experiment lasted nearly thirty years, for a quantity of broken chalk and sifted coal 
cinders was spread on December 20, I842, over distinct parts of a field near Down House, which had existed as pasture for a very long time. At the end of November, I 87 I, a trench was dug across this part of the field, and the nodules of chalk were found buried seven inches. A similar change took place in a field covered with flints, where in thirty years the turf was compact without any stones. A pathway formed of loose-set flagstones was similarly buried by worms, and became undistinguishable from the rest of the lawn. And these are but a few of the evidences of the wonderful action of worms, collected by the activity of Charles Darwin and his sons.

Earthworms were not only scrutinised in their out-ofdoor work, but were kept in confinement and studied. It appears they swallow earth both to make their burrows and to extract all nutriment it may contain; they will eat almost anything they can get their skin over. From careful calculation it was shown that worms on an average pass ten tons of the soil on an acre of ground through their bodies every year. It is, then, but a truism to say that every bit of soil on the surface of the globe must have passed through their bodies many times. 'They were discovered to work mainly by night, when hundreds may with care be discerned, with tails fixed in their burrows, prowling round in circles, rapidly retreating into holes, and strongly resisting efforts to extract them. It was found by careful study that they have no sense of hearing, but a most remarkable sensitiveness to vibrations of the earth or even to contact with air in motion. No book Darwin wrote was fuller of interesting and undoubtedly correct observations. 
In concluding, the author enforces the claims of worms on the gratitude of archreologists, as they protect and preserve for an indefinitely long period every object not liable to decay which is dropped on the surface of the land, by burying it beneath their castings. It is thus that many tesselated pavements and other ancient remains have been preserved; but, on the other hand, worms have undermined many old massive walls and caused them to subside, and no building is in this respect safe unless the foundations are at least six or seven feet beneath the surface, below which depth worms cannot work. Worms also prepare the ground in an excellent manner for plant life, periodically exposing the mould to the air, sifting it so that no stones larger than the particles they can swallow are left in it, mingling the whole intimately together, burying all decaying objects within reach of the roots of the plants, allowing air to penetrate deeply into the earth. "When we behold a wide, turf-covered expanse, we should remember that its smoothness, on which so much of its beauty depends, is mainly due to all the inequalities having been slowly levelled by worms. It is a marvellous reflection that the whole of the superficial mould over any such expanse has passed, and will again pass, every few years through the bodies of worms. The plough is one of the most ancient and most valuable of man's inventions; but long before he existed the land was in fact regularly ploughed, and still continues to be thus ploughed by earthworms. It may be doubted whether there are many other animals which have played so important a part in the history of the world, as have these lowly organised creatures." 
After this last book Darwin felt much exhausted, and wrote: "I feel so worn out that I do not suppose I shall ever again give reviewers trouble." His brother Erasmus's death in the same year was the severance of a link with early days. Yet for some months he continued in a moderate degree of health, still working. For some weeks however in the following March and April he was slightly unwell, and the action of his heart became so weak that he was not allowed to mount the stairs. On Tuesday, April I 8 , he was in his study examining a plant which he had had brought to him, and he read the same evening before retiring. Till the day of his death he did not become seriously ill. On that day the heart, which had so long done its duty, failed, and about 4 p.m., on April I9, I882, Charles Darwin breathed his last in peace, aged seventy-three years, two months, and seven days. 


\section{CHAPTER XI.}

7 HE death of Charles Darwin focussed, as it were, 1 into one concentrated glow the feelings of admiration, and even reverence, which had been growing stronger and stronger in the years since the "Origin of Species" was published. It soon became evident that a public funeral in Westminster Abbey was very generally called for, and this being granted, a grave was chosen in the north aisle and north-east corner of the nave, north of and side by side with that of Sir John Herschel, and ten or twelve feet only from that of Sir Isaac Newton. On April 26, I882, a great representative host of scientists, literary men, politicians, and theologians assembled for the final scene. The pallbearers were the Dukes of Devonshire and Argyll, the Earl of Derby, Mr. J. Russell Lowell (then American Minister in London), Mr. W. Spottiswoode (President of the Royal Society), Sir Joseph Hooker, Mr. Alfred Russel Wallace, Professor Huxley, Sir John Lubbock, and Canon Farrar. The Bishop of Carlisle, preaching at the Abbey on the following Sunday, admitted that Darwin had produced a greater change in the current of thought than any other man, and had done it by per- 
fectly legitimate means. He had observed Nature with a strength of purpose, pertinacity, honesty, and ingenuity never surpassed.

"The career of Charles Darwin," wrote The Times on the day of his funeral, "eludes the grasp of personal curiosity as much as of personal enmity. He thought, and his thoughts have passed into the substance of facts of the universe. A grass plot, a plant in bloom, a human gesture, the entire circle of the doings and tendencies of nature, builds his monument and records his exploits. . . The Abbey has its orators and ministers who have convinced senates and swayed nations. Not one of them all has wielded a power over men and their intelligences more complete than that which for the last twenty-three years has emanated from a simple country house in Kent. Memories of poets breathe about the mighty church. Science invokes the aid of imagination no less than poetry. Darwin as he searched, imagined. Every microscopic fact his patient eyes unearthed, his fancy caught up and set in its proper niche in a fabric as stately and grand as ever the creative company of Poets' Corner wove from sunbeams and rainbows."

"Our century is Darwin's century," said the Allgemeine Zeitung. The Neze York Herald described his life as "that of Socrates except its close." The Nene Freie Presse said truly that his death caused lamentation as far as truth had penetrated, and wherever civilisation had made any impression.

A movement was at once set on foot for securing a. worthy public memorial of Darwin. Subscriptions. 
flowed in abundantly, and came from all countries of Europe, the United States, the British Colonies, and Brazil. Sweden sent the astonishing number of 2296 subscriptions; persons of all ranks contributed, from a bishop to a seamstress. Over $\mathcal{E}_{4,000}$ in all was subscribed, and it was resolved, in the first place, to procure the best possible statue. This work was entrusted to Mr. Boehm, R.A., with admirable results. Permission was obtained to place it in the great hall of the British Museum of Natiural History, South Kensington, and here it was unveiled on June 9, I 885 , by the Prince of Wales, who accepted the statue on behalf of the Trustees of the British Museum from Professor Huxley as representing the subscribers. It is agreed that the statue is excellent, the attitude easy and dignified, the expression natural and characteristic. The only defect is that the

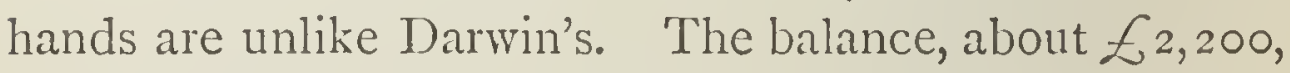
remaining over from the fund, was given to the Royal Society to be invested for the promotion of biological studies and researches.

The conditions under which Darwin lived were just those in which, as The Saturday Revicue put it, his sweet and gentle nature could blossom into perfection. "Arrogance, irritability, and envy, the faults that ordinarily beset men of genius, were not so much conquered as non-existent in a singularly simple and generous mind. It never occurred to him that it would be to his gain to show that he and not some one else was the author of a discovery. If he was appealed to for help by a fellowworker, the thought never passed into his mind that he had secrets to divulge which would lessen his importance. 
It was science, not the fame of science, that he loved, and he helped science by the temper in which he approached it. He had to say things which were distasteful to a large portion of the public, but he won the ear even of his most adverse critics by the manifest absence of a mere desire to shine, by his modesty, and by his courtesy. He told honestly what he thought to be the truth, but he told it without a wish to triumph or to wound. There is an arrogance of unorthodoxy as well as an arrogance of orthodoxy, and if ideas that a quarter of a century ago were regarded with dread are now accepted without a pang, the rapidity of the change of opinion, if not the change itself, is largely due to the fact that the leading exponent of these ideas was the least arrogant of men."

Geniality and genuine humour must be remembered as among the many delightful traits in Darwin's character. Mr. Edmund Yates, in his "Celebrities at Home" (second series), describes his as a laugh to remember, "a rich Homeric laugh, round and full, musical and jocund." "At a droll suggestion of Mr. Huxley's, or a humorous doubt insinuated in the musical tones of the President of the Royal Society (Sir Joseph Hooker), the eyes twinkle under the massive overhanging brows, the Socratic head, as Professor Tyndall loves to call it, is thrown back, and over the long white beard rolls out such a laugh as we have attempted to describe."

Exceptionally good-hearted and sympathetic as a man, Darwin discovered his life-work, and did it, in spite of a most powerful hindrance, in the best possible manner, with the least possible waste of force. But, more than doing his work, he set others to work, incited them, 
suggested to them, aided them, scattered among them seeds which, finding fertile soil, sprang up and bore fruit a hundredfold. His greatness is as much in what he caused others to do as in what he did himself. Even in arousing antagonism, though by the gentlest means, he did a great work, for he secured examination and criticism in such bulk that the whole world was leavened by his doctrine; and in controversy no man has any disagreeable reminiscence of him. Many have cause to bless the day when they first came into communication with Darwin, to find him welcome them, encourage them, place his own vast stores of knowledge and thought at their disposal, and, best of all, make them love him naturally as a dear friend.

Darwin's was one of those open and frank minds which are entrenched behind no rampart of isolating prejudice, and elevated on no platform of conscious superiority. It was equally natural to him to ask and to give information. No one ever was more accessible to all who genuinely sought his aid in their inquiries or their projects; no one ever more truly sought information from all quarters whence truth was attainable. Hence the mass of his letters to all kinds of persons is enormous, and only a small proportion, probably, will ever be published. His letters are like his conversation, free, frank, without a trace of arrière pensée, praising others where possibleand no man ever found it more possible to praise others more genuinely-depreciating himself and his work most unduly. "You so overestimate the value of what I do," he writes on one occasion, "that you make me feel ashamed of myself, and wish to be worthy of such praise." 
Again, "You have indeed passed a most magnificent eulogium on me, and I wonder that you were not afraid of hearing 'oh, oh,' or some other sign of disapprobation. Many persons think that what I have done in science has been much overrated, and I very often think so myself, but my comfort is that I have never consciously done anything to gain applause." Here we see the scientific man occupying the highest possible moral standpoint as a seeker after truth. His election as one of the honorary members of the Physiological Society was to him a "wholly unexpected honour," and a "mark of sympathy" which pleased him in a very high degree.

"Work," he writes on another occasion, "is my sole pleasure in life." "It is so much more interesting to observe than to write." So long as he could devise experiments and mark the results he continued to do it, rather than prepare his voluminous notes on many subjects for publication. "Trollope, in one of his novels, gives as a maxim of constant use by a brickmaker, "It is dogged as does it,' and I have often and often," wrote Darwin, "thought this is a motto for every scientific worker." How faithfully he adopted it himself those who read through any one of his experimental books can appreciate. He habitually read or heard some good novel as a recreation, and took a by no means restricted interest in general literature.

Considering how usual it is for leading thinkers to be drawn into controversy, even when most desirous of avoiding it, it is remarkable how little Darwin was mixed up with hotly-debated questions. "I hate controversy," he writes, "and it wastes much time, at least with a man" 
who, like myself, can work for only a short time in a day." One of the few occasions on which he appeared as a champion of a cause was on the question of vivisection, in which a chivalrous feeling led him to intervene with the following letter to Professor Holmgren, of Upsala University, which was published in The Times of April I8, r88r. "I thought it fair," he wrote, "to bear my share of the abuse poured in so atrocious a manner" on all physiologists."

"Dear Sir,-In answer to your courteous letter of April 7, I have no objection to express my opinion with respect to the right of experimenting on living animals. I use this latter expression as more correct and comprehensive than that of vivisection. You are at liberty to make any use of this letter which you may think fit, but if published I should wish the whole to appear. I have all my life been a strong advocate for humanity to animals, and have done what I could in my writings to enforce this duty. Several years ago, when the agitation against physiologists commenced in England, it was asserted that inhumanity was here practised, and useless suffering caused to animals; and I was led to think that it might be advisable to have an Act of Parliament on the subject. I then took an active part in trying to get a Bill passed, such as would have removed all just cause of complaint, and at the same time have left physiologists free to pursue their researches-a Bill very different from the Act which has since been passed. It is right to add that the investigation of the matter by a Royal Commission proved that the accusations made against our 
English physiologists were false. From all that I have heard, however, I fear that in some parts of Europe little regard is paid to the sufferings of animals, and if this be the case I should be glad to hear of legislation against inhumanity in any such country. On the other hand, I know that physiology cannot possibly progress except by means of experiments on living animals, and I feel the deepest conviction that he who retards the progress of physiology commits a crime against mankind. Any one who remembers, as I can, the state of this science half a century ago, must admit that it has made immense progress, and it is now progressing at an ever-increasing rate.

"What improvements in medical practice may be directly attributed to physiological research is a question which can be properly discussed only by those physiologists and medical practitioners who have studied the history of their subjects; but, as far as I can learn, the benefits are already great. However this may be, no one, unless he is grossly ignorant of what science has done for mankind, can entertain any doubt of the incalculable benefits which will hereafter be derived from physiology, not only by man, but by the lower animals. Look, for instance, at Pasteur's results of modifying the germs of the most malignant diseases, from which, as it so happens, animals will, in the first place, receive more relief than man. Let it be remembered how many lives, and what a fearful amount of suffering have been saved by the knowledge gained of parasitic worms through the experiments of Virchow and others on living animals. In the future every one will be astonished at the in- 
gratitude shown, at least in England, to these benefactors of mankind. As for myself, permit me to assure you that I honour, and shall always honour, every one who advances the noble science of physiology.

$$
\begin{aligned}
& \text { "Dear sir, yours faithfully, } \\
& \text { "Charles Darwin." }
\end{aligned}
$$

As an experimenter Darwin was by no means overconfident either in his methods or his power of obtaining results. He simply took the best means open to him, or that he could devise, applied them in the best way known to him, and calmly studied the result. "As far as my experience goes," he wrote, in reicrence to experimental work, "what one expects rarely happens." On another occasion, after working like a slave at a certain investigation, "with very poor success;" he remarks, "as usual, almost everything goes differently to what I had anticipated." How few investigators have the magnanimity which appears in this confession. But more than this, it is an indication of the rare patience with which he stuck at a subject till he knew all he could read or discover or develop in connection with it. It was "dogged" that did it; "awfully hard work" sometimes. In reference to an attempt of his to define intelligence, which he regarded as unsatisfactory, after remarking that he tried to observe what passed in his own mind when he did the work of a worm, he writes: "If I come across a professed metaphysician, I will ask him to give me a more technical definition with a few big words, about the abstract, the concrete, the absolute, and the infinite. But sincerely, I should be grateful for any suggestions; for it will hardly 
do to assume that every fool knows what 'intelligent' means."

Inasmuch as it must necessarily be of great interest to know the attitude which so great a thinker as Darwin adopted towards Christianity, revelation, and other matters of theology, we give unabridged two letters which were written without a view to publication, and were published after his death without the authorisation of his representatives. Having been widely published, however, it is right that they should be given here.

The first of these was sent in I 873 to N. D. Deedes, a Dutch gentleman, who wrote to ask Darwin his opinion on the existence of a God:

"It is impossible to answer your question brienly; I am not sure that I could do so even if I wrote at some length. But I may say that the impossibility of conceiving that this grand and wondrous universe, with our conscious selves, arose through chance, seems to me our chief argument for the existence of God; but whether this is an argument of real value, I have never been able to decide. I am aware that if we admit a first cause, the mind still craves to know whence it came and how it arose. Nor can I overlook the difficulty from the immense amount of suffering through the world. I am, also, induced to defer to a certain extent to the judgment of the many able men who have fully believed in God; but here, again, I see how poor an argument this is. The safest conclusion seems to be that the whole subject is beyond the scope of man's intellect, but man can do his duty." 
The second letter was addressed to Nicholas, Baron Mengden, a German University student, in whom the study of Darwin's books had raised religious doubts. It is dated June 5,1879 . The following is a re-translation of a German translation:

"I am very busy, and am an old man in delicate health, and have not time to answer your questions fully, even assuming that they are capable of being answered at all. Science and Christ have nothing to do with each other, except in so far as the habit of scientific investigation makes a man cautious about accepting any proofs. As far as I am concerned, I do not believe that any revelation has ever been made with regard to a future life; every one must draw his own conclusions from vague and contradictory probabilities."

It should be added that he was greatly averse to every form of militant anti-religious controversy, and always deprecated it. He would have been the last to desire that his words should be quoted as of scientific authority, or as being more than the results of his own thought on questions which were not the subject of his life study. Let those who think that his having expressed these views is a regrettable blow to orthodox Christianity, set against it the enormous service Darwin did to reasonable natural theology by giving an intelligible key to the explanation of the universe. And let all men remember that genuine honesty such as Darwin's cannot possibly hinder the interests or the spread of truth. His declaration that "man can do his duty," implies his conviction 
that man may know what his duty is; and very many noble spirits besides Darwin have not found it possible to advance with certainty beyond this point.

As to Darwin's place in literature, that is due supereminently to his thoughts. In his expression of them he had the saving quality of directness, and usually wrote with simplicity. Incisive he was not ordinarily ; caution of his type harmonises ill with incisiveness. But what he lost thereby he gained in solidity and in permanence. Sometimes, as we have pointed out, his imagination carried him beyond his usual sober vein, and then he showed himself aglow with feeling or with sympathetic perception.

But when we speak of his imagination we pass at once to the other side of his mind-if indeed any such patient inquiry as his could have been maintained except for the imaginative side of him. This lit up his path, buoyed him in difficulties and failures, suggested new expedients, experiments, and combinations. The use of imagination in science has never been more aptly illustrated nor more beneficial than in his case. Darwin, more than any other man perhaps, showed the value, if not the essentiality, of "working hypotheses"; and if any man now wants to progress in biology, he will be foolish if he does not seek such and use them freely, and abandon them readily if disproved.

Darwin imagined grandly, and verified his imaginings as far as one man's life suffices; and no man can do more. And Darwin won, as far as a man can win, success during his lifetime. As Professor Huxley said, in lecturing on. "The Coming of Age of "The Origin of Species," "the 
foremost men of science in every country are either avowed champions of its leading doctrines, or at any rate abstain from opposing them." His prescience has in less than a generation been justified by the discovery of intermediate fossil forms of animals too numerous to be here recounted. The break between vertebrate and invertebrate animals, between flowering and non-flowering plants, between animal and plant, is now bridged over by discoveries in the life histories of animals and plants which exist to-day. Embryo animals and plants are now known to go through stages which repeat and condense the upward ascent of life; and they give us information of the greatest value as to lost stages in the path. We can, as it were, see the actual track through which evolution may have proceeded. "Thus," says Professor Huxley, "if the doctrine of evolution had not existed, palreontologists must have invented it, so irresistibly is it forced upon the mind by the study of the remains of the Tertiary mammalia which have been brought to light since I 859 ;" and again, "so far as the animal world is concerned, evolution is no longer a speculation, but a statement of historical fact."

As to the limits of the truth of Darwin's theory, Professor Huxley, writing on "Evolution in Biology," in "The Encyclopædia Britannica," says : "How far natural selection suffices for the production of species remains to be seen. Few can doubt that, if not the whole cause, it is a very important factor in that operation; and that it must play a great part in the sorting out of varieties into those which are transitory, and those which are permanent. But the causes and conditions of variation 
have yet to be thoroughly explored; and the importance of natural selection will not be impaired, even if further inquiries should prove that variability is definite, and is determined in certain directions rather than in others, by conditions inherent in that which varies."

We have not space to describe the importance of the work Darwin did in, or bearing on, entomology, changing its face and vastly elevating its importance. A volume might be compiled from his writings on this subject, as reference to Professor Riley's excellent summary (Darwin Memorial Meeting, Washington, I882) will readily show. Nor can we recount his important work in other branches of biology further than has been already done in the foregoing pages. To do so would require much more than a volume of this size.

One special department may perhaps claim notice on the ground of its supposed non-scientific character. Dr. Masters (Gardeners' Chronicle, April 22, I882) says of Darwin's service to horticulture: "Let any one who knows what was the state of botany in this country even so recently as fifteen or twenty years ago, compare the feeling between botanists and horticulturists at that time with what it is now. What sympathy had the one for the pursuits of the other? The botanist looked down on the varieties, the races, and strains, raised with so much pride by the patient skill of the florist as on things unworthy of his notice and study. The horticulturist, on his side, knowing how very imperfectly plants could be studied from the mummified specimens in herbaria, which then constituted in most cases all the material that the botanist of this country considered necessary for 
the study of plants, naturally looked on the botanist somewhat in the light of a laborious trifler. . . Darwin altered all this. He made the dry bones live; he invested plants and animals with a history, a biography, a genealogy, which at once conferred an interest and a dignity on them. Before, they were as the stuffed skin of a beast in the glass case of a museum; now they are living beings, each in their degree affected by the same circumstances that affect ourselves, and swayed, mutatis mutandis, by like feelings and like passions. If he had done nothing more than this we might still have claimed Darwin as a horticulturist; but as we shall sce, he has more direct claims on our gratitude. The apparently trifling variations, the variations which it was once the fashion for botanists to overlook, have become, as it were, the keystone of a great theory."

A valuable summary of Darwin's infuence on general philosophic thought has been given by Mr. James Sully, in his article, "Evolution in Philosophy," in "The Encyclopædia Britannica," 9th ed., vol. viii. He, like many other thinkers, considers that Darwin has done much to banish old ideas as to the evidence of purpose in nature. Mr. Sully's views are not entirely shared, however, by Professor Winchell, an able American evolutionist ("Encyclopædia Americana," vol. ii.) who considers that the question of teleology, or of purpose in nature, is not really touched by the special principle of natural selection, nor by the general doctrine of evolution. The mechanical theorist may, consistently with these doctrines, maintain that every event takes place without a purpose; while the teleologist, or believer in purpose, may no less con- 
sistently maintain that the more orderly and uniform we find the succession of events, the more reason is there to presume that a purposeful intelligence is regulating thern. It is certainly impossible to show that the whole system of evolution does not exist for a purpose. The ranks of the evolutionists, and even of the Darwinians, as a fact, embrace believers in the most diverse systems of philosophy, including many of those who accept Christ's teaching as an authoritative Divine revelation. May not this diversity among Darwinians itself teach hope? Darwinism is held with vital grip and will therefore not become a dead creed, a fossil formula. The belief that every generation is a step in progress to a higher and fuller life contains within it the promise of a glorious evolution which is no longer a faint hope, but a reasoned faith.

"Man's thought is like Antæus, and must be

Touched to the ground of Nature to regain

Fresh force, new impulse, else it would remain

Dead in the grip of strong Authority.

But, once thereon reset, 'tis like a tree,

Sap-swollen in spring-time : bonds may not restrain ;

Nor weight repress; its rootlets rend in twain

Dead stones and walls and rocks resistlessly.

Thine then it was to touch dead thoughts to earth,

Till of old dreams sprang new philosophies,

From visions systems, and beneath thy spell

Swiftly uprose, like magic palaces,-

Thyself half-conscious only of thy worth-

Calm priest of a tremendous oracle." I

'Round Table Series. "Charles Darwin" (ISS6), by J. T. Cunningham. 
170 LIFE OF DARWIN.

Here let us leave Charles Darwin; a marvellously patient and successful revolutioniser of thought; a noble and beloved man.

THE END. 


\section{INDEX.}

A.

Ainsworth, Mr. W. F., on Darwin at Edinburgh, 22

Allen, Mr. Grant, on Darwin, 25 , $3 \mathrm{I}, 95$, II 2

Ancestry of the Darwins, II, I2, I4

Andes, 43, 45

Antiquity of man, II3

Ants, Observations on, 88, 89

Archæology and earthworms, I 5 r, I 52

Athencum, The, 22, 94, 124

B.

Bahia, 32

Bahia Blanca, 38

Beagle, H.M.S., 27, 29, 34, 36, 40, $4 \mathrm{I}, 44,45,48,52-60,65$

Bees, Observations on, 88, 89

Bell, Sir C., "Anatomy of Expression," 126

Bentley, T., and Darwin's mother, I7

Blushing, 133
Bladderwort, The, I 40

Botanical papers, I03

Botanical works, 103-108, 136-14j

Brazil, 32-36

Breeds, Domestic, 80-82, Io9-III

British Association, Darwin at, 60

Buenos Ayres, 39, 40

Burdon-Sanderson, Prof., I40

Butterwort, The, $x 40$

Button, Jemmy, the Fuegian, I30

C.

Caldcleugh, Mr., 45

Cambridge University, 24-29, I46

Candolle, A. de, I48-I5o

Carlisle, Bishop of, on Darwin, I 54, I 55

Carlyle, Thomas and Mrs., and Erasmus Darwin, I9

Character of Darwin, I55-I60, $162-165$

Chili, 43-45

Chiloe, 43

Chonos Archipelago, 43 
Chnistianity and Darwin, II5-II7, I2I, I63-6, I69

Cirripedia, Bools on, $6 \mathrm{I}-63$

Classification, 9 I

"Climbing Plants," I07

Copley medal, io6

Coral reefs, Boois on, 55-59 ; observations on, 48, 52, 55

Corfield, Mr. R., 43

Cross-fertilisation of plants, I $4 \mathbf{I}-3$

D.

Dana, Prof. J. D., on Coral Recfs, $5^{8}$

Darwin, Charles, and domestic animals, $7 \mathrm{I}$; and entomology, 25. I67; and Malthus, 72, 73; and novelists, I33; and Prof. Henslow, 24-30; and Sir C. I.yell, 3I, 5I, 52, 69, 70 ; and Sir J. Hooker, $54,74,75,78$; and slavery, 34, 35; and spelling reform, I48; as an experimenter, I62; at Cambridge, 2429 ; at Edinburgh, 22-24; "Biographical sketch of an infant," I3I ; birth, I8 ; cliaraeter of, I 55-I60, I62-I65; "Climbing Plants," I07 ; contributions to mental science, I34, I35; death of, I53; "Dcseent of Man," II2-I25; discovery of extinct mammals, 38, 39 ; elccted F.G.S., 5I, F.R.S., 52 ; experience of missionaries, 43, 47 ; experiments on ehildren, I29, I31 ; "Expression of Emotions," I26-I 35 ; fertilisation in the vegetable kingdom, I4I-3 ; "Fertilisation of Orchids," I03-I06 ; first scientific paper, 23 ; "Formation of Mould," I5O-I52; forms of flowers, I43 ; funeral of, I54; "Geology of the Beagle," 55-60; history of "Origin of Species," $64-78$; honours bcstowed on, I46; "Insectivorous Plants," I36-9; "Journal of Rcscarehes," 52 ; modesty of, 28, 66 ; on blushing, I 33 ; on Cirripedia, $6 \mathrm{I}-63$; on religion, II5-II7, I2I, I63-I69; on viviscction, I60-I62 ; "Origin of Species," $41,42,46,64-78$, 79-99; physical appearance and habits of, 100-I02, I47, $\mathrm{I}_{48} 8$; plaees named after, 48 ; portraits of, If6; power of movement in plants, I43-145; school-days of, I9-2I ; secretary of Geological Society, 5I ; sons of, I02 ; statue of, I 56 ; voyage in Beagle, 29-50

Darwin, Mrs. C., 53

Darwin, Erasmus, of Lichfield and Dcrby, I2-14, 66-67

Darwin, Erasmus, of London, I9, I 53

Darwin, Mr. Francis, IfO-I44

Darwin, Mrs. R. W. (Susannah Wedgwood), I7-I9

Darwin, R. W., of Elston, I2

Uarwin, R. W., father of Charles, I4-I 8

Darwin Sound, 48

Death of Charles Darwin, I53

"Deseent of Man," II2-I25

Digestion by plants, I37, I 38

Discovery of extinet mammals, 39 Down House, 60, IOI, I02, I $47^{-}$ I 50

E.

Earle, Erasmus, I2

Earthquake experience, 44 
Earthworms, Darwin on, 150-1 52 Edinburgh Reviezw, on "Descent of Man," I24; on Erasmus Darwin, I2, I3 ; on "Origin of Species," 94

Edinburgh University, 2I-24

Ehrenberg, 3I

Entomology, 25, I4I-3

Evolution, IIistory of, in Darwin's mind, $39,40-2,46,47,50,64-$ 78, I 12

"Expression of Emotions," I26I35

F.

Falkland Islands, 43, 60

Fertilisation, Cross and Self-, in the Vegetable Kingdom, I4I-3

"Fertilisation of Orchids," I03Io6

Fitzroy, Capt., 27, 29, 3I, 48, 49

"Forms of Flowers," I43

Fuegians, 42, 43, II2

Funeral of Charles Darwin, I54

G.

Galapagos Islands, 45-47

Gauchos, 38, 40, II6, I30

Geikie, Prof. A., on Darwin's "Coral Reefs," 58

Geographical distribution, 9I

Geological obscrvations by Darwin, $3^{\circ}, 3^{8}, 39$

Gcological papers by Darwin, 5I, $52,59,60$

Geological record, Imperfection of, $90,9 \mathrm{I}$

Gcological Society, 5I, 52, 63

"Geology of the Beagle," 53, 5560
Germination of plants, ${ }^{4} 42$

Grant, Prof., 23, 69

Greville, Dr., 23

\section{H.}

Haeckel, Prof., 7I, 72, I47

Hall, Capt. Basil, and Coral Reefs, 55

Henslow, Prof., 24-30

Hcrbert, Dean, 7 I

Ilolmgren, Prof., Letter to, I60I62

Honours conferred on Darwin, 146

Hooker, Sir J., 54, 74, 78, I40

Huxley, Prof., 65, 91, 94, 165-167

I.

Imagination, Definition of, II 5

"Insectivorous Plants," I36-I4I

Insects, 88, 89, I02-106, I36-9

Instinct, 88-90, II4

Interdependence of species, 84

J.

Jameson, Prof., 23

"Journal of Researches," 3r, 34, $36,42,46,53$

K.

Keeling Islands, $4^{8}, 5^{6}$

L.

Lamarck and Darwin, 67, 68

Linnean Society, 75-78, I07, I43, I 47

Literary position of Darwin, $\mathrm{I}_{5}$

Lubbock, Sir J., I4I

Lycll, Sir C., 3I, 5I, 52, 69, 70, 74 
M.

Magellan, Straits of, 43

Maldonado, 36, 37

Malthus on Population, 72, 73, 82

Mammals, Extinct, 38, 39, 54

Masters, Dr., on Darwin and Horticulture, I67

Matthew, Mr. P., and "Origin of Species," 97

Mcntal powcrs of man, II4-I23

Mental science, Darwin and, I34, I35

Meteyard, Miss, on R. W. Darwin, I6 ; on Wedgwood, I8

Missionaries, 43, 47

Monkeys, I32

Monkeys and man, II4, IJ5, II7, II8, I20, I22

Monte Video, 36, 40

Montgomery, James, "Pelican

Island," 55

Morphology, 64, 9I, 92

"Mould, Formation of," I52

Mount Darwin, 49

Mount, The, Shrewsbury, r7-20, 80

"Movement, Power of, in Plants," I $43-145$

Murray, Mr. J., on Coral Reefs, 59

Mylodon Darwinii, 54

N.

"Naturalist's Voyage round the World," 53

Natural Selection, 84, 85, 97-99, Io8, II7

Ncw Zealand, 47

Niata cattle, 40

Novelists, I33
O.

"Orchids, Fertilisation of," I03. Io6

"Origin of Species," 4I, 42, 46. $64-78,79-99$

Owen, Sir R., 53, 64

Oxford, Bishop of, (Wilberforce), on "Origin of Species," 95

P.

Palæontographical Society, 62

Pampas thistles, 40

Pangenesis, Hypothesis of, III

Patagonia, 4I

Peru, 45

Phillips, Prof. J., 52, 63

Physiological Selection, 87

Physiological Society, I59

Plinian Society, Edinburgh, 22, 23

Port Darwin, 48

Portraits of Darwin, 146

Punch, 123, 124

\section{Q.}

Quarterly Revieze on Darwin's " Journal," 53 ; on "Descent of Man," I24, I25 ; on "Origin of Species," 95

$\mathrm{R}$.

Ray Society, 62

Religion, II5-II7, I2I

Religious views of Darwin, $1 \sigma_{3}-6$, I69

Reptiles of Galapagos, 46

Riley, Prof. C. V., on Darwin and Entomology, 25, I67

Rio Negro, 37, 40

Rio Plata, 4I

Romanes, Mr., 87, 89, тा5, I34, I35 
Rosas, General, 38, 39

Royal medal, 62

Royal Society and Charics Darwin, 52, 62, 106

Rudimentary organs, 92

S.

Santiago, 43,45

Saturday Reviezu on Charles Darwin, I56, I57; on "Descent of Man," I25 ; on "Origin of Specics," 95

Savage man described, 49, I22, I23

"Scientific Inquiry, Manual of," 6I

Selection, Natural, 84, 85, 97-99

Selection, Physiological, 87

Semper, Prof., on Coral Reefs, $5^{8}$

Shrewsbury, 15-20

Shrewsbury school, 20

Social qualities of man, i I6

Social questions, I2I

Sonnet on Darwin, 169

Spencer, Mr. Herbert, Views of, 73, II 2

Statue of Darwin, $\mathrm{I}_{55^{-1}} 5^{6}$

Stokes, Admiral, 33, 34

Structure of human body, I I 4

Struggle for existence, $72,73,82$, 83

Sully, Mr. James, on Evolution and Design, r68

Sun-dew, I36-r39

Sweden and Darwin, ${ }^{56}$

Sydney, 48

\section{T.}

Tahiti, 47

Tasmania, 48

Tierra del Fuego, 42, 43
Times, The, on Charles Darwin, I55

Tree of Life, 85-87

Tres Montes, 44

Tucutuco, Blindness of, 68

U.

Unitarian Church, Shrewsbury, I7, $\mathrm{I9}$

V.

Valdivia, 44

Valparaiso, 43, 45

"Variation of Animals and Plants," ro8-ti2

Variations of Spccics, 79, 85-87, I08-I I2

Verde, Cape dc, 3I, 4I

"Vcstiges of Creation," 73

Vivisection, Darwin on, I60-I62

Volcanic islands, 59

W.

Wallace, Mr. A. R., 75-78

Wedgwood, Josiah, I4

Wells, Dr., and Origin of Species, 96

Winchcll, Prof., and evolution, I68-I69

Wollaston medal, 63

Woman compared with man, Irg, I20

Woodall, Mr. E., on Charles Darwin, I7, roI

\section{Y.}

Yates, Mr. E., on "Darwin at Home," I57

\section{$Z$.}

Zoological Gardens, II5, I I 32

"Zoology of the Beagle," 



\title{
B I B L I O G R A P H Y.
}

BY

\author{
JOHN P. ANDERSON
}

(British Muiseum).

\begin{abstract}
I. WORIS.
II. Mischllaneous Weitings.

III. APPENDIX-

Biography, Criticism, ete. Magazine Articles.

IV. Chronological, list of Wonks.
\end{abstract}

\section{WORKS.}

Narrative of the Surveying Voyages of His Majesty's Ships Adventure and Beagle between the years $1820^{\circ}$ and 1836 , describing their examination of the Soutliern Shores of Sonth America, and the Beagle's circumnavigation of the globe. [With appendices and addenda]. 3 vols. London, 1839, 8vo.

Vol. iii. is the "Journal and Remarks, 1832-1836," by Charles Darwin. The appendix to vol. ii. has a distinct title-page and pagination. Some copies of this work were issued in 2 vols., the third being complete in itself, and sold separately with the title "Journal of Researches into the Geology and Natural History of the various countries visited by I.M.S. Beagle, under the command of Captain Fitzroy, R.N., from 1832 to 1836. By Charles Darwin, Esq.," etc.
Journal of Researches into the Natural History and Geology of the Countries visited during the Voyage of H.M.S. Beagle romnd the World, under the command of Captain Fitzroy, R.N. Second edition, corrected, with additions. (MTurray's Colonial and Home Library.) London, 1845,8 vo.

This has been reprinted witlı a new title-page reading, "A Naturalist's Voyage Round the World, etc."

The Zoolcgy of the Voyage of H.M.S. Beagle, under the command of Captain R. Fitzroy, during the years 1832-36. Edited and superintended by C. D. Part i., Fossil Mammalia, by R. Owen. (Part ii., Mammalia, described by G. R. Waterhonse, with a notice of their habits and ranges by C. D. Part iii., 
Birds, described by J. Gould, with a notice of their habits and ranges by C. D., with an anatomical appendix by T. C. Eyton. Part iv., Fish, described by L. Jenyns. Part v., Reptiles, described by T. Bell.) 5 parts. London, 1840-39-43, $4^{\circ}$.

he Structure and Distribution of Coral Reefs. Being the first part of the Geology of the Voyage of the Beagle, under the command of Captain Fitzroy, 1832 to 1836 . London, 1842, 8 vo.

Geological Observations on the Volcanic Islands, visited during the voyage of H.M.S. Beagle, together with somc brief notices on the Gcology of Australia and the Cape of Good Hope. Being the second part of the Geology of the Voyage of the Beagle, etc. London, 1844, 8vo.

Geological Observations on South Anierica. Being the third part of the Geology of the Voyage of the Beagle, under the command of Captain Fitzroy, etc. London, 1846,8 vo.

The Structure and Distribution of Coral Reefs, by C. D. With three plates. Second edition, revised. London, 1874, 8vo.

Geological Observations on the Volcanic Islands and parts of South America, visited during the voyage of H.M.S. Beagle, by C. D. Second edition, with maps and illustrations. London, 1876,8 vo.

A Monograph on the Fossil Lepadidx, or Pedunculated Cirripedes of Great Britain. (Paloeontographical Society.) London, 1851, 4 to.
$\Lambda$ Monograph of the sub-class Cirripedia, with figures of all the species. (Ray Society). 2 vols. London, 1851-54, 8 vo.

A Monograph of the Fossil Balanidx and Verrucidx of Great Blitain. (Palocontographical Society.) London, 1854, 4 to.

On the Origin of Species by means of Natural Selection, or the prescrvation of favoured races in the struggle for life. By C. D. London, 1859, 8 vo.

-Fifth thousand. London, 1860,8 vo.

Third edition, with additions and corrections. London, 1861, 8 vo.

- Fourth edition, with additions and corrections. London, 1866, 8 vo.

Fifth edition, with additions and corrections. London, 1869, 8 vo.

-Sixth edition, with additions and corrections. London, 1872, 8 ro.

On the Various Contrivances by which British and Foreign Orchids are fertilised by Insects, and on the good effects of intercrossing. By C. D. With illustrations. London, $1862,8 \mathrm{vo}$.

Second edition. With illustrations. Lolldon, 1877, 8 vo.

The Movements and Habits of Climbing Plants. By C. D. [From the Journal of the Linncan Society.] London, 1865,8 vo.

Sccond edition, revised. With illustrations. London, 1875, 8vo.

The Variation of Animals and Plants under domestication, by C. D. With illustrations. 2 vols. London, 1868,8 vo. 
The Variation of Animals and Plants under domestication. Second edition, revised. Fourth thousand. With illnstrations. 2 vols. London, 1875, 8vo.

Second edition, revised. Fifth thonsand. With illnstrations. 2 vols. London, 1885, 8vo.

The Deseent of Man, and Selection in relation to Sex. By C. D. With illustrations. 2 vols. London, 1871, Svo.

Second edition, revised and augmented. Tenth thousand. London, 1874, 8vo.

Second edition, revised and a ugmented. Seventeenth thousand. London, 1883, 8vo.

The Expression of the Emotions in Man and Animals. By C. D. With photographic and other illustrations. London, 1872 , 8 vo.

Insectivorons Plants. By C. D. With illnstrations. London, 1875, Sio.

The Effects of Cross and SelfFertilisation in the Vegetable Kingdom. By C. D. London, $1876,8 v 0$.

The Different Forms of Flowers on Plants of the same Species. By C. D. With illustrations. Lomilon, 1877, 8ro.

The Power of Morement in Plants. By C. D., assisted by Francis Darwin. With illustrations. London, 1880, svo.

The Formation of Vegetable Nould through the Action of Worms, with obscrvations on their habits. By C. D. With illustrations. London, 1881, Sro. -Fifth thousand (corrected). London, 1881, 8vo.

Sixtl thousand (corrected). London ; 1882, 8vo.

\section{MISCELLANEOUS WRITINGS.}

For private distribution. The following pages contain extraets from letters addressed to Professor Henslow by C. Darwin, Esq., printed for private distribution among the Members of the Cambridgo Plilosophical Socicty in consequence of the geological notices which they contain, etc. [Cambridge, 1835.] $8 \mathrm{vo}$.

Note sur la découverte de quelques Ossemens Fossiles dans l'Amérique du Sud.

Annal. Sci. N'at.2nd Ser. ('/oology).

Toln. vii., 1837, pp. 319, 320.

Notes upon the lihea Americana.

Zool. Soc. Proc., vol, v., 1S37, pp. $35,36$.

Remarks upon the Habits of the Genera Geospiza, Camarhynchns, Cactornis, and Certhidea of Gould.

Proc. Zool. Soc., 1837, p. 49.

Sur trois Espièces du Genre Felis.

linstitut. Tom. vi., 1838, No. 235, pp. 210, 211.

On the formation of Monld (1837).

Geol. Soc. Proc., vol. ii., 1838, pp. 574-576; Geol. Soc. Trans., vol. v., 1840, pp. 505-510; Froriep, Notizen. Bd. vi., 1838, col. 180-183.

Observations of proofs of recent elevation on the Coast of Chili, marle during the smrvey of H.M.S. "Beagle," commanded by Capt. Fitzroy (1837).

Geol. Soc. Proc., vol ii., 1\$33, pp. 446-449.

A sketel of the denosits containing extinct Mammalia in tho neighbourhood of the Plata (1837).

Geol. Soc. Proc., vol. ii., 1838, pp. 542-544; Ann. Sci. Nat. 'Tom. vii., (Zool.) 1837, pp. 319, 320. 
On certain areas of elevation and subsidence in tho Pacific and Indian Oceans, as deduced from the study of coral formations (1837).

Geol. Soc. Proc., vol. ii., 1S38, pp. 552-551; Froriep, Notizen. Bd. iv., 1838, col. 100-103.

Geological Notes made during a survey of the East and West Coasts of South America in the years 1832, 1833, 1834, and 1835; with an account of a transverse section of the Cordilleras of the Aniles between Valparaico and Mendoza.

Geol. Soc. I'roc., vol. ii., 1838, pp. 210-212.

Origin of saliferous deposits. Salt Lakes of l'atagonia and Iua Plata. Geol. Soc. Jour., vol. ii. (pt. 2), 1S38, 1p. 127, 1ES.

On the colmexion of certain volcanic phenomena, and on the formation of mountain chains, and the effects of continental elevations.

Geul. Soc. Proc., vol, ii., 1838, pp. 654-660; Genl. Soc. I'rans., vol. v., 1840, pp. 601-0.32; I'ongendortt, Annal. IBd. lii., 1841, pp. 4\$4-496."

Monographia Chalciditum, by Francis Valker. (Vol. ii., Species collected by C. Darwin.) Isondon, 1839, 8vo.

Note on a rock seen on an iceberg in $16^{\circ}$ South Latitude.

Geog. Soc. Jour., vol. ix., 1839, pp. 528,529 .

Ueber dio Luftschifferei der Spinnen.

Frorien, N. Not. Bd. Ixxvii., No. 222, 1839, pp. 23, 24.

Ohservations on the Parallel Roads of Glen Roy, and of other parts of Lochaber in Scotland, with an attempt to prove that they are of marine origin.

Phil. Trans., 1839, pp. 39-82; Edinb. New Phil. Jour., vol. xxvii., 18:i'), pl. 395-403.
On a remarkable bar of Sandstone off Pernambuco, on the coast of Brazi!.

Phil. MIag., vol. xix., 1S11, pp. 257-260.

Notes on the effects produced by the ancient glaciers of Caernarvonsliire, and on the Boulders transported by floating ice.

Edinb. New. Plit. Jour., vol. xxxiii., 1842, pp. 352, 353.

On the distribution of the erratic boulders, and on the contemporaneous unstratified deposits of South America (1841).

Geol. Soc Proc., vol. iii., 1S12, pp. 425-430 ; Geol. Soc. Trans., vul. vi., 1842, pp. 415-432.

The structure and distribution of Coral Reefs.

Geog. Soc. Jour, , vol xii., 1812, pp. 115-119; Poggendorf, Annal. 13d. lxiv, 1845, pp. 503-613; Júlinb. New Phil. Jour., vol. xxxiv., 1813, pp. 47-50.

Observations on the structure and propagation of the genus Sagitta. Ann. Nat. Mist. Tom. xiii., 1SH, pp. 1-6; Ann. Sc. Nat. ('ool.) 'Jom. i., 1844, pp. 360-365; Froriep, Notizen. Bd. xxx., 1S44, col. 1-6.

Brief descriptions of several Terrestrial Planarixe and of some remarkable Marine species, with an account of their habits.

Ann. Nat. Ilist., vol. xiv., 1914, pp. 241-251.

All Account of the Fine Dust which often falls on vessels in the Atiantic Occan. 26-30.

On the Geology of the Falkiand Islands.

Geol. Soc. Jour., vol. ii., 1S16, pp. 267-274.

On the Transportal of Erratic Bonklers from a lower to a higher level.

Geol. Soc. Jour,, vol. iv., 1848, pp. 315-323. 
A Manual of Scientific Inquiry; prepared for the use of Her Majesty's Navy, and travellers in general. Edited by Sir Joln F. W. Herschel. London, 1849, Svo.

This work, which has run through several editions, consists of a series of papers by various writers. Charles Darwin wrote "Geology," pp. 156195.

On British Fossil Lepadidæ.

Geol. Soc. Jour., vol. vi. 1850, pp. 439, 4.10 .

Analogy of the structure of some Volcanic Rocks with that of Glacier's.

Edinb. Royal Soc. Proe. vol. ii., 1851, pp. 17, 18.

On the power of icebergs to make rectilinear uniformly-airected grooves across a subınarine undulatory surface.

Phil. Mrag., vol. X., 1855, pp. 96-98.

On the action of Sea-water on the germination of Secds (1856).

Linn. Soc. Jour., vol. i., 1857 (Bot.), pp. 130-140.

On the agency of Bees in the Fertilisation of Papilionaceous Flowers, and on the crossing of Kidney Beans.

Ann. Nat. Ilist., vol. ii., 1858, pp. 459-465; Gardeners' Chronicle, 1857, pp. 725, and 1858, pp. 824, 844 .

On the 'I'endency of Species to form Varieties; and on the l'erpetuation of Varieties and Species by Natural Means of Selection. By C. D. and Alfred Wallace.

Jour. Proc. Linn. Soc., vol. iii., 1859, pp. 45-62.

On the variation of organic beings in a state of nature; on the natural means of selection; on the comparison of domestic races and true species.

Linn. Soc. Jour., vol iii., 1859, (Zool.) pp. 46-53; Halle, Zeitsehr. Gesell. Nat Bul. xvi., 1860, pp.425-459.
Fertilisation of Vinces.

Gardeners' Chronicle, 1861, pp. 552, 831,832 .

On the 'Two Forms, or Dimorphic

Condition, in the species of

Primula, and on their remarkable Sexual Relations.

Linn. Soc. Jour., vol. vi., 1862 (Dut.), pp. 77-96.

On the three remarkable sexual forms of Catasctum triclentatum, an Orchid in the possession of the Linnean Society.

Linn. Soc. Jour., vol. vi., 1862 (Bot.), pp. 151-157.

Observations sur l' hétéromorphisme des fleurs et ses conséquences pour fécondation.

Annal. Sci. Nat. 'Tom. xix., 1863, (Bot.) pp. 204-255.

On the thickness of the Pampean formation, near Buenos Ayres.

Gcol. Soc. Jour., vol. xix., 1863, pp. 68.71.

On the existence of two forms, and on their reciprocal sexual relation, in several species of the genus Linum.

Linn. Soc. Jour., vol. vii. (Bot.), 1863, pp. 69-83.

On the so-called "Auditory sac" of Cirripedes. 116.

Nat. Hist. Revicw, 1863, pp. 115,

Ou the sexual relations of the three forms of Lytlirum Salicaria (1864).

Linn. Soe. Jour,, vol. viii., 1865, (Bot.) pp. 169-196; Archives Sci. Phys. Nat. Tom. xxiii., 1865, pp. 69-72.

On the movements and habits of Climbing Plants (1865).

Linn. Soc. Jour., vol. ix., 1S67, (Bot.) pp. 1.118 ; Flora, vol. xlix., 1866, pp. 241.252, 273-282, 321-325, $337-345,375-378,3 \$ 5-393$.

Queries about Expression for Anthropological Inquiry.

Report of Sinithsonian Institution for 1867, p. 324 . 
Note on the Common Broom (Cytisus Scoparius).

Linn. Soc. Jour., vol. ix., 1867 (Bot.), p. 358.

On the character and hybrid-like natire of the offspring from the illegitimate unions of dimorphic and trimorphic plants.

Linn. Soc. Jour., vol. x., 1869 (Bot.), pp. 393-437.

On the specific difference between Primula veris, Brit. Fl. (var. officinalis, Linn.), P. vulgaris, Brit. Fl. (var. acaulis, Linn.) and P. elatior, Jacq. and on the hybrid nature of the common Oxlip. With supplementary remarks on naturally-produced hybrids in the genus Verbascum.

Linn. Soc. Jour., vol. x., 1869 (Bot.), pp. 437-454.

De la variation des animaux et des plantes sous l'action de la domestication. ('Transl.)

Archives Sci. I'hy/s. Nat. Tom. xxxiv., 1869, pp. 41-66.

The Fertilisation of Winterflowering Plants.

N'ature, vol. i., 1869, p. 85.

Notes on the Fertilisation of Orchids.

Amn. Nag. Nat. Hist., vol. iv., 1869, pp. 141-159.

Note on the habits of the Pampas Woodpecker: Colaptes campestris. 706 .

Zool. Soc. Proc., 1870, pp 705,

Pancrenesis. 503.

Nature, vol. iii., 1871, pp. 502,

Fertilisation of Leschenaultia.

Gardener's' Chronicle, 1871, p. 1166.

Origin of certain Instincts.

Nature, vol. vii., 1873, pp. 417, 418.

On the males and complemental males of certain Cirripedes, and on rudimentary structures. 433.

Nature, vol, viii., 3873, pp. 431.
Pcrception in the lower animals. Zoolngist, vol. viii., 1873, p1. 3488 3489 ; Nature, vol. vii., 1873 , p. 360.

Fertilisation of the Fumariacere.

Nature, vol. ix., 1874, p. 460.

Flowers of the Primrose destroyed by birds.

Nature, vol. ix., 1874, p. 482 ; vol. $x_{.}, p, 24$.

Sexual Selection in relation to Monkeys.

Nature, vol. xv., 1876, pp. 18, 19.

Testimonial to Mr. Darwin. Evolution in the Netherlands. Letter of Mr. Darwin.

Nature, vol. xv., 1877, pp. 410-412.

A Biographical Sketch of an Infant.

If ind, vol. ii. (No. 7, July 1877), pp. 2\$5-294. Les Débuts de l’intelligence; Esquisse biographique d'un petit enfant, Revue Scientifique, tom. 13, 1877, pp. 25-29.

The Contractile Filaments of the Teasel.

Nature, vol. xvi., 1877, p. 339.

Fritz Müller on Flowers and

Insects.

Nature, vol. xvii., 1877, p. 78.

Note on Fertilisation of Plants. Gardeners' Chronicle, 1877, p. 246. Transplantation of Shells.

Nature, vol. xviii., 1878, p. 120.

Flowers and their unbidden gruests,

from the German of Dr. A.

Kerner. With a nrefatory letter by C. D. London, 1878, 8vo.

Erasmus Darwin. By iınst Krause. Translated from the German by W. S. Dallas. Wit! a preliminary notice by Charles Darwin. London, 1879, 8vo. Originally appeared in "Kosmos." Charles Darwin wrote the life, pp. 1.127 for the English edition, which on the publication of the work in book form in Germany (1850) was translated and appears in that edition, pp. 1.72. A copy of this work in the Library of the British Museum contains MS. Notes by Samuel Butler. 
Fritz Miiller on a Frog having Eggs on its back: on the Abortion of the Hairs on the Legs of certain Caddis Flies, etc. 464.

Nature, vol. xix., 1879, pp. 462 .

Rats and Water Casks.

Nature, vol. xix., 1879, p. 481.

Fertility of Hybrids from the Common and Chinese Goose.

Nature, vol. xxi., 1880, p. 207.

The Sexual Colours of certain Butterflies.

Nature, vol. xxi., 1880, p. 237.

The Omari Shell Mounds. 562.

Nature, vol. xxi., 1880, pp. 561,

Sir Wyville Thomson on Natural Selection.

Nature, vol. xxiii., 1880, p. 32.

Black Sheep.

Nature, vol. xxiii., 1880, p. 193.

Novements of Plants.

Nature, vol. xxiii., 1881, p. 409.

Mr. Darwin on Vivisection.

Nature, vol. xxiii., 1881, p. 583.

The Mlovements of Leaves. 604 .

Nature, vol. xxiii., 1881, pp. 603,

Inheritance.

Nature, vol. xxiv., 1881, p. 257.

Leaves injured at night by free radiation.

Nature, vol. xxiv., 1881, pp. 459.

On the Bodily and Mental Development of Infants.

Nature, vol. xxiv. 1881, p, 565.

Studies in the Theory of Descent, by August Weismann. Translated and edited by R. Meldola, with a prefatory notice by Charles Darwin. 3 pts., London, 1882, 8 vo.

The parasitic habits of Molothrus.

Nature, vol. $\mathbf{x \times v} ., 1882$, pp. 51, 52.

The action of Carbouate of
Ammonia on the roots of certain plants.

Linn. Soc. Jour. (Bot.), vol. xix., 1882, pp. 239-261 ; abstract by Mr: Francis Darwin in Nature, vol. xxv., $1882, \mathrm{pp}, 489-490$.

The action of Carbonate of Ammonia on Chlorophyll Bodies.

Linn. Soe.Jour.(Bot.), vol. xix. 18s2, pp. 262.284; abstract by Mr. Francis Darwin in Nature, vol. xxv. 1882, pp. 489, 490 .

On the dispersal of freshwater bivalves. 530 .

Nature, vol. Xxv., 1882, pp. 529,

On the Modification of a Race of Syrian Street Dogs by means of Sexual Selection. By Dr. Van Dyck. With a preliminary notice by Charles Darwin.

Proc. of the Zool. Soc. of London, 1882, pp. 367-370.

Mental Evolution in Animals. By George John Romanes. With a posthumous essay on Instinct, by Charles Darwin. London, 1883, 8vo.

Mémoire inédit sur l' instinct.

Revue Sciéntifique, tom. vi. 1883, pp. 749,750 .

The Fertilisation of Flowers. By Prof. Hermann Mueller. 'T'ranslated and edited by D'Arcy W. Thompson. With a preface by Charles Darwin. Loudon, 1883, 8vo.

Notes on Parasites collected by C. D., by T. Spencer Cobbold. Jour, Linn. Soe. (Zoology), vol. xix., 1885, pp. 174-178.

\section{III.-APPENDIX.}

Biography, Critichem, eto.

The European Literature unon Cliarles Darwin and his Wurka. is so extensive that it is only possible to give a selection. 
Alams, W. H. Davenport.Master Minds in Art, Seienee, and Letters. London, 1886, 8 ro.

Charles Darwin, with portrait, pp. 251-276.

Allen, Grant.-The Evolutionist at Large. [Reprinted from the St. James's Gavette.] London, 18s1, 8vo.

-English Worthies. Edited by Andrew Lang. Charles Darwin, by G. A. London, 1885, 8vo.

Argyll, Duke of.-WThe Reign of Law. London, 1867, 8vo.

References to Cliarles Darwin.

The Unity of Nature. London, 1884, 8vo.

Numerous references to Charles Darwill.

Armstrong, R. A. - Modern Sermons. No. 3. Charles Darwin, by the Rev. R. $\Lambda$. Armstrong. Manehester [1S85], Sro.

Aveling, Edward B.-The Stu. dent's Darwin. (International Library of Science and Freethought, vol. ii.) London, 1881, Svo.

-Darwinism and Small Families. London, 1882, 8vo.

The Religious Views of Charles Darwin. London, 1883, 8 vo.

Baildon, Henry B.-The Spirit of Nature, being a series of interpretative essays on the history of matter from the atom to the flower. London, 1880, 8\%o.

Balfour, Franeis M.-A Treatise on Comparative Embryology, 2 vols. London, 1880-1, 8vo.

Bateman, Frederie. - Darwinism tested by language; with a preface by Edward Meyriek Goulburn, Dean of Norwich. London, 1877, 8vo.

Bennett, A. W.-The Theory of Natural Selection from a mathe. matical point of view. (Read before section D of the British Assoeiation, at Liverpool, Sept. 20, 1870).

Bennett, D. M. - The World's Sages, Infidels, and Thinkers. New York, 1876, 8vo.

Darwin, pp. 846-818.

Benson, Lawrenee S.-Philosophic Reviews. Darwin answered; or, Evolution a myth, etc. New York, 1875, 8vo.

Bentham, George._- "Addresses of George Bentham, President, read at the meetings of the Linnean Soeiety, 1862-1873."

Berkeley, Hon. G. C. Grantley F. - Faet against Fietion. With some remarks on Darwin. 2 vols. London, 1874, 8vo.

Bernardo, D. di.-Il Darwinismo e le speeie animali. Sicna, 1881, 8vo.

Bianeoni, J. Joseph.--La Théorie Darwinienne et la Création dite Indépendante. Bologne, 1874, 8 ro.

Biologieal Soeicty of Washington. -Proeeedings of the Biolowical Soeiety of Washington. With the addresses read on the oeension of the Darwin Nemorial Meeting, May 12, 1882. Washington, 1882, 8vo.

With vol.xxv, of the Smithsonian Miscellaneous Collections. The addresses delivered on the occasion were-Introductory by Theodore Gill; Biographical Sketch by William II. Dall; The P'lillosophic Bearings of Darwinism, by John W. Powell; Darwin's Investigations on the relation of Plants and Insects, by C. V. Riley; Darwin as a Botan- 
ist, by L. F. Ward; Darwin on Emotional Expression, by F. Baker ; a Darwinian Bibliography, by F. W. True.

Blind, Mathilde.-Shelley's View of Nature contrasted with Dar. win's. London, 1886, 8vo.

Only 25 copies of this lecture were printed for private distribution.

Boase, Henry S. - A few words on Evolution and Creation, etc. London, 1882, Evo.

Braubach, W.-Religion, Moral, und Philosophie der Darwin' schen Artlehre. Neuwied, 1869, 8 ro.

Bree, C. R.-Species not Transmutable, nor the result of secondary causes. Being a critical examination of $\mathrm{Mr}$. Darwin's work entitled "Origin and Variation of Species." London [1860], 8ro.

An Exposition of Fallacies in the Hypothesis of Mr. Darwill. Londoll, 1872, 8vo.

Büchner, Ludwig.-Sechs Vorles. ungen über die Darwin'sche Theorie, etc. Leipzig, 1868, 8vo.

-Conférences sur la Théorie Darwinienne de la Transinuta. tion des Espèces, etc. Leipzig, $1869,8 \mathrm{vo}$.

Butler, Samuel.-Evolution, old and new; or, the theories of Buffon, Dr. Erasmus Darwin, and Lainarck, as compared with that of Mir. Charles Darwin. London, 1879, 8vo.

Second edition.

1882, 8vo.

Unconscious Memory, etc. London, 1880, 8vo.

-Luck or Cumning, as the main means of organic modification? An attempt to throw additional light upon the late Mr. Charles
Darwin's Theory of Natural Selection. Lonácn, 1887, 8vo. Candolle, Alphonse de.-Histoire desScienceset des Savants depuis deux Siècles, suivie d'autres études sur des sujets scientifiques, en particulier sur la Selection dans l'Espćce Humaine. Genève, 1873, 8vo.

- Darwin considéré au point de vue des causes de son succès et de l'importancede ses travaux. Denxième édition. Genève, 1882, 8ro.

Canestrini, Giovanni.-La Teoria dell' Eroluzione esposta ne' suoi fondamenti come introduziono alla lettura delle opere del Dar. will e de' suoi seguaci. 'Torino, 1877, 8vo.

Carlyle, Rev. Gavin.-The Battle of Unbelief. London, $1878,8 \mathrm{vo}$.

Darwinianism and Man, pp. 149 . 173.

Carneri, B. - Sittlichkeit und Darwinismus. Wien, 1S71, Svo.

Cartoon Portraits. - Cartoon Portraits and Biographical Sketclies of Men of the Day. London, 1873, 4to.

C. R. Darwin, F.R.S., pp. 6 and 7. Cattell, Charles C.-Is Darwinism Atheistic? (The Atheistic Platform, No. viii.) London, 1881, $8 \mathrm{vo}$.

Celakovsky, Ladislav. - Uvahy Prirodovĕdecké o Darwinovĕ 'Theorii, etc. V Praze, 1877 , 8 vo.

Cleland, Jolin.-Evolution, Expression, and Sensation, etc. Glasgow, 1881, 8vo.

Cobbe, Frances Power.-Darwinism in Morals, and other Essays. London, 1872, 8vo.

Collins, Mortimer.-Pelı Sketches by a Vanished Hand; from the 
papers of the late Mortimer Collins. 2 vols. London, 1879,8 vo.

Darwinism, vol. ii., pp. 51-61. Conn, H. W.-Evolution of Today, etc. New York, 1886, 8vo. Cook, Joseph.-Boston Monday Lectures. Heredity, etc. London, 1881, 8vo.

Darwin's Theory of Pangenesis, pp. $59-79$; Darwin on the Origin of Conscience, pp. 80-99.

Cooper, Thomas. - Evolution, the Stone Book, and the Mosaic Record of Creation. London, 1878, 8vo.

Thoughts at fourscore, and earlier. A Medley. London, 1885,8 vo.

Claarles Darwin and the Fallacies of evolution, pp. 132-162; The Origin of Species, pp. 322-334.

Cope, E. D.-Origin of the Fittest. London, 1887, 8vo.

Cunningham, J. T.-The Round Table Series. (No. 5.) Charles Darwin, Naturalist. Edinburgh, 1886, 8vo.

Curtis, George T.-Creation or Evolution? A Philosophical Inquiry. London, 1887, 8vo.

Darwin, Charles R.-The Darwinian Theory of the Transmutation of Species examined by a Graduate of the University of Cambridge. Second edition. London, 1868, 8vo.

The Fall of Man: or, the Joves of the Gorillas. A popular scientific lecture upon the Darwinian Theory of Development by Sexual Selection. By a Learned Gorilla. Edited by the author of "The New Gospel of Peace." [Illustrated.] New York, 1871, 8vo.

Our Blood Relations; or, the Darwinian Theory. Londoll, 1872, 8vo.
Darwin, Clarles R. - Stammen wir von den Affen $a b$ ? [Being $a$ reply to Darwin's Origin of Species.] Dresden, 1872, 8 ro.

The Fall of Man; an answer to Mr. Darwin's “'Descent of Man," being a complete refutation, by common sense arguments, of the Theory of the Development of the human race by means of natural selection. London, 1873, 8vo.

The Darwinian Theory examined. London, 1878, 8vo.

Bondige uiteenzetting van let Darwinisme voor leeken in de natuurwetenschappen. Deventer, 1878, 8ro.

-What Mr. Darwin saw in lis voyage round the world in the ship "Beagle." [Illustrated.] New York [1879], 8\%o.

Die Grundlehren der wahren Naturreligion nach Darwin und Hæckel. Berlin, 1881, 8vo.

-Darwinism stated by Darwin himself. Characteristic passages from the writings of $\mathrm{C}$. $\mathrm{D}$., selected and arranged by $\mathrm{N}$. Sheppard. New York, 1884, 8 vo.

Daubeny, Charles.-Remarks on the final causes of the Sexuality of Plants, with particular reference to Mr. Darwin's work on the Origin of Species. Oxford, 1860, 8vo.

Miscellanies : being a collection of Memoirs and Essays, etc. 2 vols. Oxford, 1867, 8 vo.

Remarks on the Final Causes of the Sexuality of Plants, etc, vol. ii., pp. 85-107.

Davey, Samuel.-Darwin, Carlyle, and Dickens, with other essays. London [1876], 8vo. 
Davies, Charles M. - Mystic London; or, pliases of occult life in the Mctropolis. London, 1875,8 vo.

"Darwinism on the Devil," pp. 179-197.

Diman, Jcremiah Lewis. - The Theistic Argument as effectcd by rccent theories. A course of lectures deliverch at the Lowell Institute in Boston, [Edited, with a preface, by G. P. Fisher.] Boston, 1881, 8vo.

Dixon, Charles.-Evolution without Natural Selection; or, the Segregation of Specics without the aid of the Darwinian IIypothesis. London, 1885, 8 ro.

Dolel, afterwards Dollel-Port, Arnold. Dionenerc Schöpfungsgeschichte nach dem gegenwärtigen Stande der Naturwissenschaften, etc. Leipzig, 1875,8 vo.

Draper, Professor. - "On the Intellectual Development of Europe, considered with refercnce to the vicws of Mr. Darwin and others, that the Progression of Organisms is determined by Law." Papcr read at the Oxford Meeting of the British Association, 1860, with discussion. (Gardeners' Chronicle, Aug. 6, 1860, pp. 713, 714.)

Drcher, Eugcn.-Der Darwinismus und seine Consequenzen in wisscnchaftlicher und socialer Beziehung. Halle, 1882, 8vo.

Drury, John B.-Veddes Lectures, 1883. Truths and Untruths of Evolution. New York [1884], Svo.

Dubois-Reymond, Emil.-Darwin versus Galiani. Berlin, 1876, 8 ro.
Dubois-Reymond, Émil.-Fricd. rich II. in Englischen Ur. theilen. Darwin und Kopernicus, etc. Leipzig, 1884, 8 vo.

Ducasse, Félix. - Étude historique et critiquc sur le Transformisme, etc. Paris, 1876,8 vo.

Dumont, Léon A.-Haeckel et la théorie de l'évolution en Allc. magne. Paris, 1873,8 vo.

Duval, Mathias. - Le Darwinisme. Paris, 18s6, 8vo.

Dykes, Rev.J. Oswald.-Problems of Faith, a contribution to present controversies, being a third series of Lectures to Young Men, etc. With a preface by the Rev. J. O. D. London, 1875, 8 vo.

Disputcd Questions of Belief ; bcing Lectures to Young Men, etc. London, 1874, 8vo.

Evolution: An Exposition and Critique by the Rev. H.S. Paterson, pp. 183-252.

Elam, Charles. - Winds of Doctrine: being an cxamination of the modern theories of automatism and evolution. London, 1876,8 vo.

Encyclopædia Americana. - The Encyclopædia Americana, etc. New York, 1885, 4 to.

Articles Darwin and Darwinism, vol. ii., pp. 542-555.

Encyclopædia Britannica. - The Encyclopædia Britannica. Ninth odition. Vol 8. Edinburgh, 1877,4 to.

The article Evolution by Professor Huxley and James Sully.

Ereolani, Luigi. - Darwinismo. Reggio, Calabria, 1882, 8vo.

Essays.-English Essays. Hamburg, 1869, $12 \mathrm{mo}$.

Mr. Darwin's Theories, vol. ii., pp. 106-138. Reprinted from the Westminster Review, Januiry 1869. Fawcett, Henry. - On the Method 
of Mr. Darwin in his Treatise on the Origin of Species. (Report of the 31st Mecting of the British Association, 1861, p. 141.) London, 1862, 8vo.

Fće, A.-Le Darwinisme, ou Examen de la Théorie relative à l' origine des espèces. Paris, $1864,8 v 0$.

Appeared originally in the Gazette IIebdomadaire de Brédecine et de Chirurgie, 1864.

Ferrière, Émile.-Le Darwinisme. Paris, 1872, 8vo.

Ferris, Benjamin G. - A new theory of the Origin of Species. New York, 1883, 8vo.

Fiske, John. - Darwinism, and other Essays. Lolldon, 1879, $8 \mathrm{vo}$.

Another edition.

Boston

[U.S.] 1885, 8vo.

-Outlines of Cosmic Philosophy, based on the Doctrine of Evolution, etc. 2 vols. London, 1874,8 vo.

Numerous references to Charles Darwin.

Excursions of an Evolutionist. London, 1884, 8vo.

In memoriam: Charles Darwin, pp. 337-369.

-The Destiny of Man viewed in the light of his Origin. Boston [U.S.] 1884, 8vo.

The Idea of God as affected by modern knowledge. London, 1885,8 vo.

Flourens, MT. J. P.-Examen du livre de M. Darwin sur l'origine des espèces. Paris, $1864,12 \mathrm{mo}$. Flower, Professor W. H. On Palæontological Evidence of Gradual Modification of Animal Forms, read at the Royal Institution of Great Britain, April 25, 1873 (Journal of the Royal Institution).
Force, M. F.-Pre-historic Man. Darwinism and Deity. The Mound Builders. Cincinnati, 1873,8 vo.

Gaiton, Francis. - Hereditary Genius : an inquiry into its laws and consequences. London, 1869, 8vo.

References to C. D.

English ALen of Science : their nature and nurture. London, 1874,8 vo.

References to C. D.

Inquiries into Human Faculty and its Development. Lomlun, 1883,8 vo.

References to C. D.

Geology.-Geology and its Teach. ing, especially as it relates to the Development Theory as propounded in "Vestirres of Creation" and Darwin's "Origin of Species." Reprinted from tho "Leeds Express." London, 1861, $12 \mathrm{mo}$.

Gibson, Rev. Charles B.--Philosophy, Science, and Revelation. Second edition. London, 1874, 8 vo.

Goblet d' Alviella, Count Eugène. - The Contemporary Evolution of Raligious'Thought in England, America, and Inửia. Translated by J. Moden. London, 1885, 8 vo.

Graham, William.-The Creed of Science, religious, moral, and social. London, 1881, 8 vo.

Gray, Asa. - Natural Selection not inconsistent with Natural Theology. A free examination of Darwin's Treatise on the Origin of Species and of its American Reviewers. London, 1861, 8vo.

Appeared originally in the Atlantic MIonthly for July, August, and October, 1860. 
Gray, Asa.-Darwiniana: Essays and Reviews pertaining to Darwinism. New York, 1876, 8vo.

Greaves, C. A.-The Science of Life ; and Darwin's Hypothesis. Two lectures. London [1873], $8 \mathrm{vo}$.

Hacckcl, Ernst H .P. A.-Generelle Morphologie der Organismen. Allgcmeine Grundziige der organischen FormenWissenschaft, mechanisch bcgrïndet durch die von Charles Darwin, etc. 2 Bue. Bcrlin, 1866,8 vo.

Natürliche Schöpfungsges. chichte, etc. Bcrlin, 1868, 8 ro.

Die heutige Entwickelungslehre im Vcrhältnisse zur Gesammtwissenschaft. Stuttgart, 1877,8 vo.

Gcsammelte populäre Vorträgc aus dem Gcbiete der Entwicke. inngslehre. Bonn, 1878-79, 8 vo.

Anthropogenie, oder Entwicke!nngsgeschichte des Menschen, etc. Leipzig, 1874, 8ro. -The Evolution of Man, ctc. From the German of E. H. [With plates.] 2 vols. London, 1879, 8vo.

Ziele und Wege der hentigen Entwickelungs-geschichte. Jena, 1875,8 vo.

Die Naturanschauung von Darwin, Goethc, und Lamarck. Jena, 1882, 8vo.

The Pedigree of Man : and other Essay's, by E. Haeckel. Translated from the German by Edward B. Aveling. (Inter. national Library of Science and Freethought, vol. 6.) London, 1883, 8vo.
Hall, A. Wilford.-Tho Problem of Human Life,... with a rcview of Darwin, IIuxlcy, ctc. Reviscd edition. New York, 1880, 8vo.

Hallier, Ernst.-Darwin's Lelrre und dic Specification. Hamburg, 1865, 8vo.

Hartmann, C. R. E. von.-Wahr. heit und Irrthum im Darwinismus. Berlin, 1875, 8vo.

Darwinisinus und Thicrpro. duction. München, 1876, 8 vo.

Le Darwinismc, traduit de l'Allemand par Gcorgcs Guéroult. Paris, 1877 , 8ro.

Hartscn, F. A.-Darwin cn de Godsdicnst. Ecne populaire uitecnzetting van het Darwin. isme, etc. Lcyden, 1869, Sro.

Hcller, Karl B. -Darwin und der Darwinismus. Wien, $1869,8 \mathrm{r}^{\circ}$.

IIenslow, George.-The Thcory of Evolution of living things, and the application of the principles of evolution to religion considered as illustrative of the "Wisdom and Beneficence of the Almighty." London, 187?, $8 \mathrm{ro}$

The Fertilisation of Plants: a lecturc [on D.'s Cross-and-SelfFertilisation of Plants] delivered 8th March, 1877. (Transactions of the Watford Nat. Hist. Soc. Vol. i., 1878, pp. 201-210.)

Hcrtwig, R. - Gedächtnissrede auf Charles Darwin. Königsbcrg, 1883, 4 to.

Hertzka, Theodor.-Die Uigeschichte der Erde und des Menschen, I. Vorlesung uiber die Darwin'sche Theorie, etc. Pest, 1871, 8vo. 
Hicks, It. E.-A Critique of Design-Arguments, etc. New York, 1883, 8vo. 330 .

Darwinisun and Design, pp. 308-

Hodge, Charles. - What is Darwinism? London, 1874, 8vo.

IIoffinann, Hermann.-Untersuchungen zur Bestimmung des Werthes von Speeies und Varietät, etc. Giessen, 1869, 8 vo.

Huber, Johannes.-Die Lehre Darwin's kritiseh betraehtet von Dr. J. H. München, 1871, 8 vo.

Humiecki, M.-Darwinizm. Lwów, 1878,8 vo.

Huxley, Thomas Henry. - Evidence as to Man's Place in Nature. London, 1863, 8vo. -Lay Sermons, $\Lambda$ ddresses, and Reviews. London, 1870, 8vo.

The Origin of Species, pp. 280-327. Reprinted from the Westminster Review, April 1860 ; Criticisms on "The Origin of Species," pp. 328350. Reprinted from the Natural History Review, 1864.

Critiques and

London, 1873, 8vo.

Mr. Darwin's Critics, pp. 251-302.

Reprinted from the Contemporary Review, 1871.

- Science and Culture, and other Essays. London, 1881, 8 vo.

The Coming of Age of the "Origin of Species," pp. 310-324.

Jacoby, Paul.-Études sur la Sélection dans ses rapports avec l'hérédité chez l'homme, etc. Paris, 1881, 8vo.

Jaeger, Gustav.-Die Darwin'. sche Theorie und ihre Stellung zu Moral und Religion. Stuttgart [1869], 8vo.

- In Sachen Darwin's insbesondere contra Wigand. Stutt. gart, 1874,8 vo.
James, Constantin.-Du Darwin. isme, ou l'homme-singe. Paris, 1877, 8vo.

Johns, Rev. B. G.-Moses, not Darwin: a sermon. London, 1871, 8vo.

Kalischer, S.-Teleologie und Darwinismus. Berlin, 1878, $8 \mathrm{vo}$.

Kirby, W. F.-Evolution and Natural Theology. London, $1883,8 \mathrm{vo}$.

Darwin and his Critics, pp. 50-68.

Kirk, Rev. John.-The Doctrine of Creation according to Darwin, $\Lambda$ gassiz and MIoses. Londoll, 1869, 8vo.

Kleinenberg. Nicolaus. - Carlo Darwin e l'opera sua. Discorso commemorativo letto nell' aula della R. Universitá di Messina il 21 Maggio 1882. Messina, 1882, 8vo.

Klönne, B. H.-Onze Voorouders volgens de Theorie van Darwin en het Darwinisme van Winkler. Met gravuren. 'S Hertogenbosch, 1869, 8vo.

Kölliker, Albrecht. - Entwicklungsgeschichte des Mensehon und der löheren Thiere, etc. Leipzig, 1861, 8vo.

Zweite Auflage. Leipzig, 1879, 8vo.

Kramer, Paul. - Theorie und Erfahrung. Beiträge zur Beurtheilung des Darwinismus. Halle a/S., 1877. 8vo.

Krause, Ernest.-Erasmus Darwin und seine Stellung in der Geschichte der DescendenzTheorie. Mit seinem Lebensund Charakterbilde von C. Darwin. Leipzig, 18s0, 8vo.

References to C. D's fanily. Originally appeared in Kosmos. The life by $C . D$. is a translation from the linglish edition (1879). 
Krause, Ernest.-Erasmus Darwin. - Translated from the German by W. S. Dallas. With a preliminary notice by C. Darwin. Portrait and woodcuts. Lon. don, 1879, 8vo.

The Life by C. D. pp. 1.127. There is a copy of this work in the library of the British Museum which contains MS. Notes by Samuel Butler.

Charles Darwin und sein Verhältniss zı Deutschland. (Gesammelte Kleinere Schriften, Bd., 1:) Leipzig, 1885, 8vo.

Laing, F. H.-Essays on Religion and Literature. By various writers. Edited by Henry Edward, Archbishop of Westminster. 'Third Series, London, 1874, 8vo.

Darwinisin brought to Book, by the Rev. F. H. Laing, pp. 257-283.

Laing, Sidney Herbert. - Darwinism Refuted. An Essay on Mr. Darwin's Theory of "Tho Descent of Man." London, 1871, 8vo.

Lamessan, J. L. de.-Étude sur la Doctrine de Darwin. Isa lutte pour l'existence et l'association pour la lutte. Paris, 1881, 8 vo.

Lankester, Edwin Ray.-Degeneration : a chapter in Darwinism. (Nature Series.) London, 1880, $8 \mathrm{vo}$.

Lecomte, A.-Le Darwinisme et l'origine de l'bomme. Paris, $1873,12 \mathrm{mo}$.

Le Conte, Joseph.-Religion and Science: a series of Sunday Lectures on the relation of natural and revealed religion, etc. London, 1874, 8 vo.

Le Hon, H.-L'Homme Fossile en Europe, etc. (AppendiceAbrégé de la Théorie de Darwin ou Transformisme, traduit de l'Italien du Prof. Omboni).
Deuxièmo édition. Bruxelles, 1868, 8vo.

Lessona, Michele.-Carlo Darwin. Roma, 1883, 8vo.

Commemorazione di Carlo Darwin (Atti della R. Accad. delle Scienze di Torino, vol, xviii. 1882, pp. 709-718). Torino, 1882, 8vo.

Lewes, George Henry.-Problems of Life and Mind. Three Series. London, 1874-79, 8vo.

Lichthorn, C.-Die Erforschung der physiologischen Naturgesetze der menschlichen Geistestätigkeit auf der Grundlage der neuesten grossen Entdeck. ungen Dubois - Reymond's, Darwin's und Häckel's iiber die organische Natur, etc. Breslau, 1875,8 vo.

Liddon, H. P. - The Recovery of St. Thomas: a sermon preaclied in St. Paul's Cathedral, April 23, 1882, with a prefatory note on the late Mr. Darwin. London, 1882, 8vo.

Lindsay, William Lauder.-Mind in the Lower Animals in health and disease. 2 vols. London, 1879,8 vo.

Löwenthal, Eduard.-Herr Schleiden und der Darwin'sche Arten - Entstehungs - Humbug. Berlin, 1864, 8 vo.

Lyell, Sir Charles._Life, Letters, and Journals of Sir Charles Lyell, Bart. Edited by his sister-in-law, Mrs. Lyell. 2 vols. London, 18s1, 8vo. C. D.

Contains a number of Letters to

Lyon, W.P.-Homoversus Darwin: a judicial examination of statements recently published by Mr. Darwin regarding “The 
Descent of Man." Second edition. London, [1872], 8vo.

Third edition. London, [1873], 8vo.

I'Cann, Rev. James. - Anti-Darwinism: with Professor Huxley's reply. Glasgow, 1869, 8vo.

IIcCarthy, Justin.-A History of Our Own Times. A new edition. 4 vols. London, 1882, 8 vo. 283.

Charles Darwin, vol. iv., pp. 286-

Maclaren, James.-A Critical Examination of some of the principal arguments for and against Darwinism. London, 1876, 8 vo.

Natural Theology in the Nineteenth Century. London, 1878,8 vo.

Mäklin, F. W.-Allmänna betraktelser öfver den Darwinska descendenslärens förtallande till ochmed de organiska formernas och isynnerhet djurens geografisk utbredning. Helsingfors, 1882, 8vo.

Mantegazza, Paolo.-Commemorazione di Carlo Darwin. Discorso del Professor P. M. Firenze, 1882, 8vo.

Martins, C. - La théorie de l'évolution en histoire naturelle. Paris, 1876, 8 vo.

Maschi, Luigi._-Confutazione delle Dottrine Transformistiche di Huxley, Darwin, etc. Parma, $1874,8 \mathrm{~V}$

Menza, Antonino.-Il Concetto Scientifico di Darwin sviluppato dalla Filosofia Positiva. Saggio critico di A M. Catania, 1882, 8 vo.

Meteyard, Eliza.-A group of Englishmen (1795 to 1815), be. ing records of the younger
Wedgwoods and their friends. London, 1871, 8vo.

Numerous references to the Dar. win family.

Meyer, A. B.-Charles Darwin und Alfred Russel Wallace. Ihro ersten Publicationen über die "Entstehung der Arten" nebst einer Skizze ihres Lebens und einem Verzeichniss ihrer Schriften. Erlangen, 1870, 8vo.

Miall, L. C.-The Life and Works of Charles Darwin; a lecture delivered to the Leeds Philosophical and Literary Society, on February 6, 1883. Leeds, 1883, 8vo.

Michelis, Fr.-Die Naturwissenschaftliche Unhaltbarkheit der Darwinschen Hypothese. Heidelberg, 1885, 8vo.

Mivart, Saint George.-On the Genesis of Species. London, 1871, 8vo.

Men and Apes, an exposition of structural resemblances bearing upon questions of affinity and origin. London, 1873, 8vo. Contemporary Evolution. An essay on some recent social changes. London, 1876, 8vo.

Nature and Thought; an introduction to a Natural Philosophy. London, 1882, 8vo. Second edition. London, 1885,8 vo.

Moleschott, Jacob.—Carlo Roberto Darwin. Commemorazione pronunziata a nome degli studenti dell' Università di Roma, 25 di Giugno, 1882. Toriuo, 1882, 8vo.

Karl Robert Darwin. -Denkredo gehalten im Collegio Romano im Namen der Studirenden der Hochschule zu Rom 
von Jacob Moleschott. Giessen, 1883, 8 ro.

Morris, Rev. F. O.-Difficulties of Darwinism. Read before the British Association at Norwich and Exeter, in 1868 and 1869, etc. London, 1869, 8vo.

All the Artieles of the Darwin Faith. London [1882], Sro.

Moss, Arthur B.--Darwin against Moses. London [1885], Svo.

Miuller, Aug.-Ueber die erste Entsteluung organischer Wesen und deren Spaltung in Arten. Berlin, 1866, 8 vo.

Miiller, F. Max. - Lectures on the Science of Language, etc. Two Series. London, 1861-64, 8vo. Several editions.

Chips from a German Workshop. 4 vols. London, 1867-75, 8 vo.

My reply to Mr. Darwin, vol. iv., pp. $433-472$; reprinted from the Contemporary Review, Jan. 1875.

'The Seience of Thought. Loulon, 1887, Svo.

Miuller, Fritz-Für Darwin. Leipzig, 1864, 8vo.

liaets and Arguments for Darwin. Translated from the German by W. S. Dallas, Lon. don, 1869, 8vo.

Mïller, Hermann.-Anwendung der Darwinschen Lehre auf Bienen. Berlin, 1872, 8vo. -Die Befruchtung der Blumen durch Insekten und die gegenseitigen Anpassungen beider, etc. Leipzig, 1873, 8 vo.

The Fertilisation of Flowers.

Transiated and edited by D'Arey W. Thompson, with a preface by C. Darwin. With illustrations. London, 1883, $8 \mathrm{ro}$.
Müller Hermann. -Alpenblumen, ihre Befruchtung, durch Insekten und ihre Anpassungen an diesel ben. Mit Abbildungen, etc. Leipzig, 1881, 8vo.

Nature Series. - Charles Darwin. Memorial notices reprinted from "Nature." [With a portrait on steel by C. H. Jeens.] London, 1882, 8vo.

Contents-Introductory Notice, by T. H. Huxley ; Life and Character, by G. J. Romanes; Work in Geology, by Archibald Geikie; Work in Botany, by W. T. T. Dyer ; Work in Zoology, by G. J. Romanes; Work in Psychology, by G. J. Romanes.

Neaves, Lord.-The Descent of Man. A continuation of an old Song. Air, "Greensleeves" (Darwin loquitur). [Blackwood's Ediuburgh Magazine, vol. 109, 1871, pp. 517-519.

Songs and Verses, social and scientific. Edinburgh, 1868, 8 vo.

The Origin of Species, pp. 1-4; The Darwinian Era of Farming, pp. 8, 9.

Nicholson, H. Alleyne.-On the hearing of certain palæonto. logical facts upon the Darwinian Theory of the Origin of Species, and on the general doctrine of Evolution. (Journal of the Transactions of the Victorica Institute, vol. ix., 1876, pp. 207-231; Discussion on preceding, pp. 231-236.

O'Neill, T. Warren. - The Refuta. tion of Darwinism; and the Converse Theory of Development. Philadelphia, 1880, 8vo.

Ormathwaite, Lord.-Astronomy and Geology compared. Lon. don, 1872, 8vo.

Remarks on the Theories of Mr. Darwin and Mr. Buckle, pp. 57-111, 
Page, David.-Strictures upon the lectures-on the subjeet, "Man - whence? where? whither? and an exposure of the Darwin ian Development'Theory, etc. Edinburgh, 1867, 8vo.

Parker, W. Kitehen.-On Mammalian Descent : the Hunterian Lectures for 1884. London, 1885,8 vo.

Paseoe, Francis P.-Notes on Natural Seleetion and the Origin of Species. London, 1884, 8 vo.

Patané, Agostino. - Il Darwinismo (a proposito dell 'opera-Di Bernardo). Acircale, 1882, 8vo.

Patterson, Robert. -The Errors of Evolution. An examination of the nebular theory, geologieal evolution, the origin of life, and Darwinism. London, 1885, 8vo.

Pawlieki, Stefan. - Czlowiek i Malpa. Ostatnie Slowo Darwina. Lwów, 1872, 8vo.

Peebles, J. M. - The Conflict between Darwinism and Spiritualism. Boston, 1876, 12 mo.

Pelzeln, August von.-Bemerkungen gegen Darwin's Theorie vom Ursprung der Spezies. Wien, 1861, 8vo.

Perrier, Elmond.-La Philosophie Zoologique avant Darwin. Paris, 1884,8 vo. $^{\circ}$

Pfaff, Friedrich.-Die Theorie Darwin's und die Thatsaehen der Geologic. Frankfurt, a.MI., 1876,8 vo.

Polo y Peyrolon, Manuel.-Parentesco entre el hombre y el Mono. Observaciones contra el Transformismo Darvinista en general y espeeialmente contra el orígen símio, etc. Madrid, 1878, 8vo.
Portanova, Gennaro.-Errori e delirii del Darwinismo. Napoli, 1S72, 8vo.

Porter, J. L. - Seience and Revelation: their destructive pro. vinces. With a review of the theories of Tyndall, Huxley, Darwin, and Herbert Spencer. Belfast, 1874, 8vo.

Powell, B. H. Baden.-Creation and its Records, etc. London, 1886, 8vo.

Pratt, John H.-The Deseent of Man, in connection with the Hypothesis of Development. A leeture, etc. London, 1871, 8 vo. Prel, Karl F. du.-Der Kampf um's Dasein am Himmel. Die Darwin'sche Formel nachgewiesen in der Meehanik der Sternenwelt. Berlin, 1874, 8 vo.

Properzi, Geremia.-Un poco di buon senso, ovvero saggio di un esamo critico popolare delle teorio pedargoriche di P. Sieiliani e delle materialistiehe dei Biichner, Darwin, ctc. Genova, 1S82, 8ro.

Psychosis.-Our Modern Pliilosophers, Darwin, Bain, and Spencer, or the Deseent of Man, Mind alid Body. A rhyme [on C. R. Darwin's "Deseent of of Man," etc.], with reasons, essays, notes and quotations. By Psychosis. London, 18S4, 8ro.

Punch.-Puncli. London, 1871, 1877, 1882, 4 to.

Our Fatmily Tree ( 6 verses), vol. 60, 1871, p. 105; Dar'vin and Pick. wick (3 verses), p. 145; The Development of Dress ( 6 verses), p. 197; A Darwinian Balladl (4 verses), p. 234 ; 'The Origin of Darwinism, vol. 61, p. 69; A Darwinian Development ( 6 verses), p. 110; Darwinian Spiritualism, p. 196 ; Punch to Dr. 
Darwin 8 verses), vol. $73,1877, \mathrm{p}$. 241 : Memorial P'oem (G lines), vol. 82, 1882, p. 203.

Pusey, S. E. B. Bouveric-Permanence and Evolution; an inquiry unto the supposed mut. ability of animal types. London, 1882, 8vo.

Quadri, Achille.-Note alla Teoria Darwilliana. Bologna, 1869, 8 vo.

Quatrefages de Bréau, $\Lambda$. de.Charles Darwin et ses précurseurs Français; étude sur lo Transformisme. Paris, 1870, 8 vo.

R. G.-The Three Barriers : notes on Mr. Darwin's "Origin of Species." Elinburgh, 1861, 8 vo.

Rade, E.-Charles Darwin und seine Deutschen Anhänger im Jahre 1876. Strassburg, 1877, Svo.

Ragusa, C, F.-Saggio critico sul Darwinismo, etc. Napoli, 1878, Svo.

Renooz, C. M.-L 'origine des animaux. Théorie réfutant celle de M. Darwin. Paris, 18s3, $12 \mathrm{nlo}$.

Reus y Balıanonde, Emilio.Estudios sobre Filosofía de la Creacion, etc. MIadrid, 1876, svo.

Richardson, George. - On the spirit in which scientifie studies should be pursued, with remarks on tlie Darwinian theory of Evolution. A lecture, etc. London, 1872, 8vo.

Rolle, Friedrich. -- Charles Darwin's Lehre von der Entstehung der Arten un Pflanzen - und Thierreich, etc. Frankfurt am Main, 1863, 8vo.

Der Mensch, seine Abstammung und Gesittung im Lichte der Darwin' schen Lehre, etc. Frankfurt am Main, 1866, Svo.

Romanes, George Joln.-Animal Intelligence. (Internationab Seicntific Series, vol. xli.) London, 1S82, Svo.

The Scientific Evidences of Organic Evolution. (Nature Series.) Londoll, 18s2, Svo.

Mental Evolution in Animals.

With a posthumous essay on Instinct by Charles Darwin. London, 1883, 8vo.

Numerous references to C. D.

Physiological Selection; au alditional suggestion on the Origin of Species. (Journal of the Linnean Socicty, vol. 19, 1885, pp. 337-411.)

Ross, James.-The Graft Theory of Disease, being an application of Mr. Darwin's Hypothesis of Pangenesis to the explanation of the phenomena of tho Zymotic, Diseases. London, 1872, 8vo.

Rossi, D. C.-Le Darwinisme et les générations spontanées, ou réponse aux réfutations de MM. P. Flourens, de Quatrefages, etc. Paris, $1870,12 \mathrm{mo}$.

Roux, Wilhelm.-Ueber die Leistungsfähigkeit der Principien der Descendenzlehre zur Erklärung der Zweckmässigkeiten des thierischen Organismus. Breslau, 1880 ; 8 vo.

- Der Kampf der Theile in Organismus, etc. Leipzig, 1881, 8vo.

Royer, Clémence.-Darwinisme. (Dictionnaire Encyclopédique des Seiences Médicales, vol. xxv., 698-767.) Paris, 18s0, 8vo.

Ruitimeyer, L.-Die Grenzen der Thierwelt. Eine Betrachtung zı 
Darwin's Lehro. Basel, 1868, 8 ro.

St. Clair, George.-Darwinism and Design; or, Creation by Evolution. London, 1873, 8vo. Schleicher, August.-Dic Darwinsche Theorie und die Sprachwissenschaft. Weimar, 1863, 8 vo.

Darwinism tested by the Science of Itanguage. Translated from the German, with preface and additional notes, by Dr. Alex. V. W. Bikkers. London, 1869, 8 ro.

Schmid, Rudolf.-Dio Darwin' schen Theorien und ihre Stellung zur Philosophie, Religion und Noral. Stuttgart, 1876, 8vo.

The Theories of Darwin, and their relation to philosophy, religrion, and morality. 'I'ranslated from the German, by G. A. Zimmermann. With an introduction by the Duke of Argyll. Chicago, 1883, svo.

Sehmidt, Eiluard Oscar.-Das Alter der Menschlneit und das Pa:alies. Zwei Vortriige von O. S. nui Franz Unger. Wien, 1866,8 vo.

-Descendenzlehre und Darwinismus. Leipzig, 1873, 8vo.

The Doctrine of Descent and Darwinism (International Scicntific Serics). London, 1875, 8vo.

Descendance et Darwinisme. Paris, 1875, 8ro.

Darwinismus und Socialdemo. cratic. Bomn, 187s, sro.

Schneider, G. II.-Der thicrische Wille, ete. Leipzig [1880], Svo. Schultze, Fritz.-Kant und Darwin. Bin Bcitrag zur Geschichte der Entwicklungslehre. Jena, 1875 , svo.

Schumann, Richard.-Darwinismus und Firche. Potsdam, $1874,8 \mathrm{vo}$.

Seidlitz, Georg.-Die Darwin'sche Thcoric. Dorpat, 1871, 8vo.

-Beitrïge zur DescendenzTheoric. Leipzig, 1876, 8vo.

Semper, Carl.-The natural conditions of existence as they affect arimal life. With maps and woolcuts. (International Scientific Serics, vol. xxxi.) London, 1881, 8vo.

Simon, Léon.-Do l'Origino des Especès, en particulicr du système Darwin: conférences, etc. Paris, 1865,8 vo.

Simonin, Amédée H.-Psychologio Humaine. Histoire de Ia Psychologie, etc. Paris, 1879, Svo.

J)arwin et le Darrinisme, rp. 418-443.

Spencer, Herbert.-First Principles. London, 1862, Svo.

The Principles of Jiology. 2 vols. London, 1861, 8vo.

Spengel, J. W.-Die Darwinsche Theoric. Berlin, 1872, Sio.

-Die Fortschritte des Darwinismus. Cöln. 1874, Sro.

Stebbing, Thomas R. R.-Darwinism. A lecture delivered before the Torquay Natural History Society, February 1, 1869. London, 1869, Svo.

Darwinism. - The Noachian Flool. A lecture delivereel before the Torquay Natural Ilistory Society, January 31, 1870. Lonton, 1870, 8vo.

Essays on Darwinism. London, 1871, 8vo.

Stephen, Leslie.-Essays on Free. 
thinking and Plain spcaking. London, 1873, 8v0.

Darwinism and Divinity, pp. $72-109$.

- Life of Henry Fawcett. London, 1885, 8vo.

Cliarles Darwin, pp. 05-102 and 239. Strimpell, Ludwig. - Dic Geisteskräifte der Menschen verglichen mit denen der Thiere. Ein Bedenken gegen Darwin's Ansicht über denselben Gegenstand. Leipzig, 1878, 8ro.

Suckling, H.-Anti-Darwin : or some reasons for not accepting his hypothesis. By the author of "Ccylon, ancient and modern" [H. Suckling]. Twickenham, 1884, $16 \mathrm{mo}$.

Swift, Elmund.-Evolution and Natural Selection in the Light of the New Church, etc. London, 1879, Svo.

Tefft, Benjamin F. - Evolution and Christianity ; or, an auswer to the Development Infidelity of modern times. Boston [U.S.], 1885, 8vo.

Thomson, George.-Evolution and Involution. London, 1850, 8 vo. Traill, H. D.-The new Lucian, being a series of Dialogues of the Dearl. London, 188t, 8vo.

Lucretius, Paley, and Darwin, pp. 287-312.

True, Frederick W.-A Darwinian Bibliography. (Smithsonian Miscellancous Collections, vol. xxv., 1883, pp. 92-101.)

I'wemlow, Maj.-Gen. George.Facts and fossils adduced to prove the Deluge of Noah and modify the transmutation system of Darwin, etc. London [1868], 8 ro.

Tyndall, John. - Fragments of Science. 2 vols. Inondon, 1879, 8vo.
Vaclali-Papale, G. - Darwinismo Naturale e Jarwinismo Sociale. Torino, 1882, Svo.

Vianna De Lima, Arthur. - Exposé sommaire des T'héories Transformistes de Lamarck, Dirwin et Hacckel. I'aris, $1885,12 \mathrm{mo}$.

Virchow, Rudolph.-Dic Freiheit der Wissenchaft in modernen Staat, etc. Berlin, 1877, 8vo.

The Freedom in Science in the Modern State. 'I'ranslated from the German. London, 1878, 8vo. "Wagner, A.-Zur Feststellung des Artbegrifles. München,1861,8vo. Wagner, Carl._Stammt der Mensch vom Affen ab? Stutt. gart, 1879,8 vo.

Wagner, Mnritz.-Dic Darwin' sche 'Theorie und das Migrationsgesetz der Organismen. Leipzig, 1868, 8 vo.

'The Darwinian Theory and the Law of the Migration of Organisms. Translated from the German of M. W. by James L. Laird. Liondon, 1873, 8ro.

Wainwright, Samuel.-Scientific Soplisins. A review of current theories concerning A toms, A pes, and Men. London, 1881, 8ro.

Walford, Edward.-Portraits of Men of Eminence in Literature, Science, and Art, etc. London, 1S66, 8vo.

Charles Robert Darwin, with portrait, vol. v., pp. 49-52.

Wallace, Alfred Russel.-Natural Selection-Mr. Wallace's reply to Mr. Bennett. (Nature, vol. iii, 1870, pp. 49,50 .)

Contributions to the theory of Natural Selection. A series of essays. London, 1871, 8vo.

Ward, Lester F.-Dynamic Sociology, or applied Social Science, etc. '2 vols. New York; 1883, 8 vo. 
Weidenlımmer, R.-Die sandwirthschaftliche Thierzucht, als Argument der Darwin' schen Theorie. Stuttrart, 1864, 8vo. WTeismann, August.-Uंber die Berechtigung der Darwin' schen Theorie. Leipzigr, 1S68, Svo. -Studien zur DescendenzTheorie. Leipzig, 1S75, etc. svo.

Studies in the Theory of Deseent. Translated and edited by R. Meldola, with a prefatory notice, by Charles Darwin. 3 pts. London, 1850-\$2, 8vo.

Werner, Hermanu.-Ueber Darwin's Theorie von der En tstehung der Arten und der Abstammung des Menschen. Elberfeld, 1876, Svo.

Weygoldt, G. P.-Darwinismus, Religion, Sittlichkeit, etc. Leiden, 1878, 8vo.

Wieser, Johann.-Mensch und Thier . . mit Riicksicht auf die Darwin' sche Descendenzlehre. Freiburg in Breisgau, 1875, 8vo.

Wiesner,Julius. - Das Bewegungsvermögen der Pflanzen. Eine kritischo Studie über das gleichnamige Werk von Charles Darwin. ["On the movements and habits of Climbing Plants."] Wien, 1881, 8vo.

Wigand, Albert.-Der Darwinismus und die Naturforschung Newtons und Cuviers. 3 Ble. Braunschweig, 1874, 8vo.

Wilberforce, Samuel. - Essays contributed to the Quarterly Review. 2 vols. London, 1874, 8vo.

Darwin's Origin of Species (July 1860), vol. i., pp. 52-103.

Wilson, Andrew. - Leisure-Time
Studies, ehiefly Biological. London, 1879, 8 vo.

References to Charles Darwin.

Chapters on Evolution. London, 1883, svo.

Numerous references to Cliarles Darwin.

Studies in Life and Sense.

With thirty-six illustrations

London, 1887, 8vo.

Winn, J. M. - Darwin. Reprinted

from The Journal of Psychological Medicine, vol. viii., part 2. London [1Ss3], 8vo.

-Modern Pscudo-Philosophy.

London, [1578], 8vo.

Woodall, Edward.-Transactions of the Shropshire Archeological and Natural History Society. Vol. viii., 1885. . Shrewsbury [1885], 8vo.

Contains a paper on Charles Darwin, contributed by Edward Woodall, pp. 1.64, with a portrait and illustrations.

-Charles Darwin. A paper contributed to the Transactions of the Shropshire Archæological Society. London [1S84], 8vo.

Worsley-Benison, H. W. S.Charles Darwin. [Reprinted from the Journal of Microscopy and Natural Science.] Bath, 1856, svo.

Wright, Chauncey.-Darwinism : being an examination of Mr. St. George Mivart's Genesis of Species. [Reprinted from tho ' North American Review,' July 1871, with additions]. London, 1871,8 vo.

Yates, E. H.-Celebritics at Home. Reprinted from "The World." London, 1877, 8 vo.

Mr. Darwin at Down. Second series, pp. 223-230.

Yorke, J. H.-Notes on Evolution and Christianity. London, 1582, sio. 
Young, J. R.-MLodern Scepticism, viewed in relation to Modern Science; more especially in reference to the doctrines of Colenso, Huxley, Lyell, and Darwin, etc. London, 1865, Svo.

Zacharias, Otto:-Zur Entwicklumgstheoric. Jena, 1876, 8vo. Charles R. Darwin und die culturlistorische Bedeutung seiner Theorie vom Ursprung der Arten. Berlin, 1882, 8vo.

\section{Magazine Articles.}

Darwin, Charles Robert. - Unscre Zeit, by J. Schönemann, Bu. 7, 1863, pp. 699-718. - Ergänzungrblätter: zur Kentniss der Gegenwart, by J. B. Carus, Bu. 3, 1868, 1p. 46-48. - Every Saturday, with portrait, vol. 10, p. 347.-Eclectic Magazine, witli portrait, vol. 13, N.S., 1871, pp. 757, 758.-Appleton's Journal of Literature, with portrait, vol. 3, 1870, pp. 439.441. -Penn Monthly Magazine, vol. 2, 1871, pp. 469-472.-Once a Week, with portrait, vol. 9, third series, $1872, \mathrm{pp} .520-523$. - Popular Science Monthly, with portrait, vol. 2, 1873, pp. 497, 498. - Nature, with portrait, by $\Lambda$ sa Gray, vol. 10, 1874 , pp. $79-81$; same article, Popular Science Monthly, vol. 5,1874 , pp. 475.480 ; American Naturalist, vol. 8, 1874, pp. 473-479. - Dublin University Magazine, with portrait, vol. 2, N.S., 1878; pp. 154-163. 一Men of Mark, with portrait, third series, 1878. - Times, April 21, 1882. - American Journal of Science by Asa Gray, vol 24,
Darwin, Cliarles Robert.

1882, pp. 453-463.-Wesleyan Methodist Magazine, by $\mathrm{W}$. Spiers, vol. 105, 1882, pp. 488494. - Saturday Review, A pril 22, 1882, pp, 481, 482.-A thenreum, April 29, 1882, рр. 541, 542 , and NTay 13, pp. 604, 605. - Academy, by Grant Allen, April 29, 1882, pp. 306, 307.Journal of Botany, by A. W. Bennett, lvol. 11, N.S., 1882 pp. 165-168. - Atlantic Monthly, by John Fiske, vol. 49, 1882, pp. 835-845.-American Natur. alist, vol. 16, 1882, pp. 487-490. -Dial, by David S. Jordan, vol. 3, 1882, pp. 2-4.-Zoolo. gist, vol. 6, thiru series, 1882 pp. 193-195. - Unsere Zeit, by J. Victor Carus, Bd. 2, 1882, pp. 200-226. - Spectator, 1882, pl. 525, 526, 557, 558.-Inquirer, by W. Binns, May 6, 1882, pp. 297, 298. - Nature, vol. 26,1882 , pp. 49-51, 73-75, $97-100,145-147,169-171$, reprinted in Nature Series, 1882. -Geological Magazine, vol. 9, N.S., 1882, pp. 239, 240.Journal of Microscopy, by $\mathrm{H}$. W. S. Worsley-Benison, vol. 5, 1886, pp. 69.92; reprinted same year.

and Chemistry. Christian Scientific Magazine, by Andrew Taylor, April 1887.

and Copernicus. Nature, ly Du Bois Reyniond, vol. 27, 1883, pp. 557, 558.

and Evolution. Cliurclı Quarterly Review, vol. 14, 1882, pp. 347-367.

and Galiani. Popular Science MIonthly, by Prof. Emil du Bois - Reymond, vol. 14. 1879, nl. 409-425. 
Darwin, Charles Robert.

and Hackel. Popular Science Monthly, by Professor Huxley, vol. 6, 1s75, pp. 592-598.

_- and his Tcachings. Quarterly Journal of Science, illustrated, vol. $3,1866, \mathrm{pp}$. 151-176.

-and Pangenesis. Scientific Opinion, vol. 2, 1869, pp. 365 367, 391-393, 407, 408.-Quarterly Journal of Science, vol. 5, 186s, pp. 295-313.

-Pangenesis as applice to the faculty of momory. Journal of Antluopology, by Alfred Sanders, Oet. 1870, pp. 144-149.

-and Philosophy.

Contem-

porary Review, by Sir A. Grant, vol. 17, 1871, lp. 275-281; same article, Littell's Living Age, vol. 109, 1871, Pp. 626631.

- cla Filosofia del Secolo XIX. Rivista Europea, by C. Bizzozero, vol. 29,1882 , pp. 5-34.

-and Spencer, Huxlcy, and Tymdall. Dickinson's Theological Anuual, by George B. Cheever, 1875, pp. 418-441.

-Animals and Plants under Domestication. Boston Review, by C. R. Bliss, vol. 9, 1869, $\mathrm{pp}$. 453-462. - Student and Intel. lectual Observer, vol. 1, 1868, pp. 179-188. - Westminster Review, vol. 35, N.S., 1869 , pp. 207-227.-Harper's New Monthly Magazine, vol. 36, 1867, pp. 58-63.- Nuova Antologia, by P. Mantegazza, tom. 8, 1868, pp. 70-93.-Das Ausland, No. 10, 1868, pp. 217-224; No. 11, pp. 246-251, and 281-286.

Answercd. Penn Monthly Magazine, vol. 6, 1875, pp. 368-372.
Darwin, Charles Robert.

- as a Botanist. Smitlısonian Miscellaneous Collections, by Lester F. Ward, vol. 25, 1883, pp. 81-86.

-as a Horticulturist. Gar. deners' Chronicle, with portrait, March 6th, 1875, pp. 308, 309.

before the Freneh Academy. Nature, vol. 2, 1870, pl. 261, 238, and 309.-Das Ausland, 1870 , pp. 855-857.

Biography of. Biograph, vol. 6, 1881, pp. 525.529.Smithsonian Miscellaneous Collections, by William H. Dall, vol 25, 1ss3, pp. 56-59.

Contributions to Philosophy. Smithsonian Miscellancous Col. lections, by John W. Towell, vol. $25,1883,1]$. 60-70.

Critics on. Contemporaly Review, by T. H. Huxley, vol. 18, 1871, pp. 443-476; reprinted in Critiques and Addresses, by Huxley, 1873.

-et ses Critiques. Revue des Deux Mondes, by Auguste Laugel, tome 74, sêconde période, 1868, pp. 130-156.

-und scine Gegner. Aus Ausland, 1871, pp. 88-91.

-Cross and Sclf-I'crtilisation in the Vegctable Kingdom. American Journal of Science, by Asa Gray, vol. 13, 3rd Series, 1877, pp. 125-141. - Nature, by W. T. Thiselton Dyer, vol. 15, 1877, pp. 329-332.

Debt of Scicnce to. Illustrated. Century, by Alfred R. Wallace, vol. 25, 1883, pp. 420-432.

Desccnt of Man. Academy, by Alfred R. Wallace, vol. 2, 1871, pp. 177-183.-.A thenrum, March 
Darwin, Cliarles Robert. 4, 1871, pp. 275-277. - Saturday Review, vol. 31,1871, pp. 276 , 277, and 315,316 . All the Year Round, vol. 5, N.S., 1871, pp. 445-450. - Nature, by P. H. PyeSmith, vol. 3, 1871, pl. 44244, and 463-465. --Revue des Denx Monles, by R. Radau, vol. 95, 1871, pp. 675-690. - Monthly Religrious Marazine, vol. 45, p. 501.--Southern Review, rol. 9, 1871, pp. 733738. -Lutheran Quarterly, by C. Thomas, vol. 2, pp. 213, etc., and 346 , etc. - Nation, by B. G. Willer, vol. 12, 1871, pp. 258-260.-Month, by A. Weli, vol 15, 1871, pp. 71-101.-Old and New, vol. 3, 1871, pp. 594600. - Quarterly Journal of Psychological Society, vol. 5, 1871, pp. 550-566.-British and Foreign Evangelical Review, by J. R. Leebody, vol. 21, 1872, pp. 1-35. - Edinburgl Review, rol. 134, 1871, pp. 195-235.Quarterly Review, vol. 131, 1871, pp. 47-90; same article, Eclectic Magazine, vol. 14, N.S., pl. 385-404, 605.611; Littell's Jiving Age, vol. 23, 4th series, pp. 67-90.-Canadian Monthly, by H. Alleyne Nicholson, vol. 1, 1872, pp. 35-45.Westminster Review, vol. 42, N.S., 1872, pp. 378-400.Baptist Quarterly, by E. Nisbet, vol. 7, 1873, pp. 204-227.Brownson's Quarterly Review, July, 1873, pp. 340-352.Journal of Speculative Philosophy, by J. H. Pepper, vol. 10, 1876, pp. 134-141.-Charing Cross, by J. C. Hollgson, vol. 6 N.S., 1878, pp. 254-266. - Doctrine of. Smithsonian
Darwin, Charles Robert.

Miscellaneous Collections, by Theodore Gill, vol. 2i, 1883, 1). $47-55$.

Expression of the Emotions in Mron and Animals. St. Patil's Magazine, by Henry Holbench, vol. 12, 1873, pp. 190-211. Ediuburgh Review, vol. 137, 1873, p. 492-528; same article, Littell's Living Arre, vol. 118,

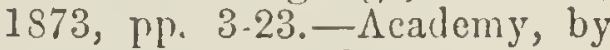
Anton Dolirn, vol, 4, 1873, pp. 209-212.-A thenæum, Nov, 9 and $16,1872,17.591$ and 631 , 632. - Saturday Reriew, vol. 34, 1872, pl. 633-635. - Smith. sonian Miscellaneous Collec. tions, by Frank Baker, vol. 25, 1883, pp. 87-92.-Revue Scientifique, by A. Bain, vol. 7, 1874, pl. 433-441.

Facts and Fancies of. Good

Words, by David Brewster, 1862, pp. 3-9.

His Biograplecrs and his Traducer. Journal of Science, vol. 5, 3rd series, 1883, pp. 203210.

His Mistake. Catholic World, vol. 39, 1884, p). 289-300.

His Work in Entomology. Smithsonian Miscellaneous Col. lections, vol. 25, 1883, pp. 70 S1.

Hypotheses of. Fortuightly Review, by G. H. Lewes, vol. 9, 1868, np. 353-373, 611-628, and vol. 10, rp. 61-s0, 492 . 509.

Hypothesis and Design in Nature. Dickinson's Theological Annual, by George F. White, 1877, pp. 404-419.

Inscctivorous Plants. Nature, by Alfred W. Bennett, vol. 12, 1875, pp. 207-209, aud 228-231. 
Darwin, Charles Robert.

Life and Work. Modern Review, by IV. B. Carpenter, vol. 3, 1882, pp. 500-524.Canadian Mlonthly, vol. 8, N.S., 1882, pp. 540.542 .

On a Future State. Spectator, 1882, p. 1249.

On Coral Recefs. Nature, by James D. Dana, vol. 10, 1874, pp. 408-410. - Nature, by John ILurray, vol. 22, 1880, pp. 351 . 354. - Proc. of the Royal Socicty, Edinb., by John Murray, vol. 10, pp. 505.518 [abstract].

On Earth Worms. Fiaser's Magazinc, by F. $\Lambda$. Paley, vol. 25 , N.S., 1s82, pp. 46.53.Nature, by George J. Romanes, vol. 24, 1881, pp. 553-556.Academy, by H. N. Moseley, vol. 20, 1881, pp. 313, 314.Athenæum, Oct. 15, 1881, pl. 499, 500.-Saturday Review, vol. 52, 1881, pp. 578, 579.

-On II is Travels. Penn

Monthly, by R. E. Thompson, vol. 2, 1871, pp. 562-572.

On Orchids. - Weldon's Regis. ter, by W. B. 'Tegetmeicr, 1862, pp. 38, 39. - Popular Science Review, vol, 1, N.S., 1877, pp. 174-180.—Edinburgh New Philosophical Magazine, vol. 16, N.S., 1862 , pp. $277 \cdot$ 285.-Das Ausland, No. 29 1862, pp. 681-685.-Das Ausland, No. 13, 1865, pp. 294-297, and No. 14, pp. 319-322.

Origin of Specics. - Saturday Review, vol. 8, 1859, pp. 775, 776. - Athonæum, Nov. 19, 1859, pp. 659, 660._Quarterly Revicw, by S. Wilberforce, vol. 108, 1860, pp. 225.264. - Edinburgh Review, vol. 111, 1860, pp.
Darwin, Charles Robert.

p. 487-532. - Atlantic Monthly, by $\Lambda$. Gray, vol. 6,1860 , pl. 109-116, and 229.239. - West. minster Review, by T. H. IIuxley, vol. 17, N.S., 1860, pr. 541.570. - American Journal of Science, reprinted in Lay Scrmons, etc. 1860 , by A. Gray, vol. $79,1 £ 60$, pp. 153.184. National Review, vol. 10, 1860 , pp. 188-214. - Nortl British lieview, vol. $32,1860, \mathrm{pp}$. 455 486 ; vol. 46, 1867, pp. 277. 318.-Christian Examiner, by J. A. Lowell, vol. 68, 1860, pp. 449.464. - British Quarterly Review, vol. 31, 1860, pp. 398 . 421; same article, Eclectic Masrazine, vol. 50, pp. 331-345. - Eclectic Review, vol. 3, N.S., 1860, pp. 217-242. —Chambers's Journal, vol. 12, 1860, pp. 388 . 391.-London Review, vol. 14, pp. 281-308.-American Presbyterian Revicw, vol. 20, pp. 349 , etc.-Macmillan's Magazine, by Henry Fawcett, vol. 3, 1860, pp. 81-92. - Edinburgh New Philosophical Journal, vol. 2, N.S., 1860, pp. 280-289.Revue des Deux Mondes, by A. Laugel, tom. 26, 1860, pp. 644 671. - Christian Observer, vol. 60, 1860, pp. 561-574.-Canadian Journal, vol. 5, N.S., pp. 367 , etc. - Canadian Journal, by W. Hincks, vol. 8, N.S., pp. 390, etc.-American Journal of Science, vol. 80, by F. Bowen, 1860, pp. 226-239. - - North American Review, vol. 90, 1860, pp. 474-506.-Register of Literature, Aug. 1860, pp. 1-7.Das Ausland, No. 5, 1860, pp. 97-101, 135-140; No. 4, 1\&67, pr. 73-80; No. 3, 1870, 
Darwin, Charles Robert.

pp. 59.62.-Revue Germanique, hy E. Claperède, tom. 16, 1861, pp. 523-559, and tom. 17, pp. 232-263. - Proccedings of the Literary and Philosophical Socicty of Liverpool, by H. H. Higgins, No. 15, 1861, pp. 42 49, and pp. 135-140. -Methodist Quarterly Review, by W. C. Wilson, vol. 43, 1861, pp. 605627.-American Quarterly Church Review, vol. 17, 1565, pp. 169198. - Revue des Deux Mlondes, by George Pouchet, tum. 85, 1870, pl.691-703. - Revue des Deux Mondes, by $\Lambda$. de Quatrefages; vol. 78, 1868, pn. 832860, Les Precurseurs Franeais de Darwin ; vol. 79, pp. 208 . 240, La Théorie de Darwin; vol. 80, pp. 61.95 and $397-452$, Discussion des Théories T'ransformistes; vol. 80, pp. 638-672, Théories de $i a$ Transformation progressive et de la Transforma. tion brusque; Origine Simienne de l'fomme. - Fortnightly Review, by G. H. Lewes, vol. 9, 1868, pp. 353-373, and 611-628. -Nation, by B. G. Wilder, vol. 12, 1871, pp. 199-201.-Month, by A. Weld, vol. 4, N.S., 1871, pp. 71-101.-Monthly Religious Magazine, vol. 50, pp. 496, etc. -Nature, by $A$. W. Bennett, vol. 5, 1872, pp. 318, 319.

-Ayassiz Viezs of the Origin of Species. Proceeding 3 of Literary and Philosophical Society of Liverpool, by C. Collingwood, No. 15, 1861, pp. 81-99.

A Characlerisation of the Origin of Spccies. Jourual of Science, by Oswald Dawson,
Darwin, Charles Robert. vol. 7, 3rd Ser., 1885, pp. 441458 .

Criticisms on the Origin of Species. Natural History lieview, by T. H. Huxley, vol. 4, 1864, pp. 566-580 ; reprinted in Lay Serinons, 1870. Cominiy of Age of the

Origin of Species. Nature, by T. H. Huxley, vol, 22, 1880, pp. 1-4; same article, l'opular Science Monthly, vol. 17, 1880, pp. 337-344.

Philosophy of Language. Frascr's Magazine, by Professor Max Müiller, vol. 7, N.S., 1873, pp. 525.541 and 659-678, and vol. 8, N.S., pl. 1-24; same article, Eclectic Magazine, vol. 18, N.S., pp. 75-88, 148-163, and 257.275 .

Max Müller on. Proccedings of Literary and Philosophical Society of Liverpool, No. 27, 1873, pp. xli-liii.

Phrenological Detincation of. Phrenological Magazine, witl portrait, vol. 1, 1880, pp. 89-92. - Power of Mlovement in Plants.

Saturday Review, vol. 51, 1881, pp. 57, 58. - Edinburgh Revicw, vol. 153, 1881, pp. 497-514.Acadeiny, by George Henslow, vol. 19, 1881, pp. 120-122. Atlenæum, Dec. 18, 18s0, pp. 817, 818.- Journal of Botany, vol. 10, 1881, pr. 375-381.Nation, by Asa Gray, Jan. 6 and 13, 1876 ; reprinted in Darwiniana, by Asa Gray, 1876.Dial, by David S. Jordan, vol. 1, 1881, pp. 255.257.

Reminisecnce of. Harper's New Montlly Magazine (portrait), by James D. Hague, vol. 69,1881, PL. 759.763. 
Darwin, Charles Robert. Studies in. Amcrican Church Review, by J. F. Garrison, vol, 27, 1875, pp. 197-218.

Testimonial to, in the Nether. lands. American Naturalist, vol. 11, 1877, lp. 295-300.

Theorics of. Dial, by A. L. Chapin, vol. 3, 1882, pp. 168, 169. I'heory of Instinct. Ninetcenth Century, by G. F. lomanes, vol. 16, 1884, pp. 434-450.

IVorks of. Westminster Rcview, N.S., vol. 62, 18s2, pp. 85-121.

Dawinian Eden. - Ovcrland Monthly, by M. G. Upton, rol. 7, 1871, pp. 159-166.Darwinian Idea-Every Saturday, vol. 10, pp. 414 , ctc.

Darvinism. - Christian Examiner, by J. A. Lowell, vol. 68, 1860, pp. 449-464.-Dublin Review, vol. 48, 1860, pp. 50-81.Unitarian Review, by W. H. Furncss, vol. 5, p. 291, etc.Unitarian Rcview, by L. J. Livermorc, vol. 3 , p. 237 , ctc. - Morgenblatt, 1862, pp. 1-6, 31-36. - Unserc Zcit, by M. J. Schlciden, Jahr. 5, pp. 50.71, and 258-277.- Eclcctic Review, vol. 4, N.S. 1863, pp. 337-345, - Gazette Hebdomadaire de Médecine et de Chirurgic, by Dr. Fée 1864, pp. 289-292, 321 . $323,337-342,353 \cdot 357,409-413$, 427-432, 481-484.—Ergänzungsblatter zur Kenntniss der Gegenwart, Bd. 1, 1866, by G. Jaeger, pp. 291.294 ; Bd. 4, 1869, by J. Huber, pp. 607-615, 670-678,728. 739. - Atlantic Monthly, by C.J. Sprague, vol. 18, 1866, pp. 415425. - New Englander, by W. N. Rice, vol, 26, 1867, pp. 603-
Darwin, Charles Robert. 635. - Student and Intellectual Observer, vol. 1, 1868, pp. 179. 188. - Proceedings of the Bristol Naturalists' Society, by Charles Jecks, vol. 3, N.S., pp, 107-113. -American Quarterly Church Revicw, vol. 21, 1870, pp. 52t536. - Das Ausland, by $\mathrm{M}$. Wagner, 1871, pp. 289.293, $322 \cdot 327,343-347,535-540,559-$ 564, 865-870, 891-894, 913.918, 916-948, 1057-1061, 1081-1085. -Bibliothcca Sacra, by F. Gardincr, vol. 29, 1872, pp. 240-289.-Transatlantic, vol. 1, 1872, pp. 139-146. - Catholic World, by F. Smitl, vol, 17, 1873, pp. 641-655. - Southern Review, vol. $12,1873, \mathrm{pp} .406$. 423. - Old and New, by Gcorge M. Kellogg, vol. 8, 1873, pp. 283-292. - Baptist Quarterly, by E. Nisbet, vol. 7, $1873, \mathrm{pp}$. 69 87, and 204-227. - Congregational Review, by S. Adams, vol. $11, \mathrm{pp} .233$, etc., 338 , etc. -New Englander, by L. 'I'. Adams, vol. $33,1874, \mathrm{pp} .741$. 769. - Old and Ncw, by G. Axford, vol. 6, pp. 655.663.Scribner's Montlily, by J. B. Drury, vol. 10,1875 , ip. 348 . 360.-Tinsleys' Magazine, by W. H. Penning, vol. 19, 1876, pp. 515-523--Bibliotheca Sacra, by G. F. Wright, vol. 33, 1876, pp. 656-694.-Catholic World, by J. Bayne, vol. 26, 1878, pl. 496-511. - Atlantic Monthly, by William James, vol. 46, 1880, pp. 441-459. - Nature, by George J. Romanes, Feb, 1887, pp. 362364.

Analogics with Calvinism. Bibliotheca Sacra, by Geo. F. Wriglit, vol. 37, 1880, j'!. 48-76. 
Darwin, Charles Robert. - and Agassiz. Popnlar Seience Montlıly, by John Fiske, vol, 3, 1873, pp. 692-705.

-and Chemistry. Christian Seience Magazine, by A. Taylor, $\Lambda$ pril $1 \& S 7$.

- and Christianity. Lakeside Monthly, by E. O. Haven, vol. 7, 1872, pp. 302-313.-Baptist Magazine, vol. 74, 1882, pp. 245-253.

- MTan in, and in Christianity. American Chureh Review, vol. 24, 1872, pp. 288-299.

and Design, St. Clair on. Dublin Review, vol. 23, N.S., 1874, pp. 232-240.

- and Divinity. Fraser's Magazine, by Leslio Stephen, vol. 5, N.S., 1872, pp. 409-421 ; same artiele, Topular Seicnce Monthly, vol 1, 1872, pp. 188 . 202.

- - and its Iiffects upon Religious Thought. Jour. of the Trans. of the Victoria Institute, by C. R. Bree, vol. 7, 1874, pp. 253570 .

-Discussion on preceding, np. 270.285 .

- and Language. North Ameriean Reriew, by W. D. Whitney, vol. 119, 1874, pp. 61.S8.Das Ausland, No. 17, 1864, pp. 397-399.

- and Language, Schleicher on.

Nature, by Max Müller, vol. 1, 1870, pp. 256-259.

- and Morality.

Canadian

Monthly, by Jolin Watson, vol. 10, 1876, pl. 319-326.Spectator, 1867, pp. 1255, 1256. - and National Life. Nature, vol. 1, 1869, pp. 183, 184.

- and licligion. Nlacmillan's Magazine, vol. 24, 1871, pp.45-
Darwin, Charles Robert.

51 ; same artiele, Eelectie Magazine, vol. 14, N.S., 1871 , pp. 25 31, and Littell's Living $\Lambda$ ge, vol. 109, 1871, pp. 621-626.

-and Schopenhaner. Journal of Anthropology, by Dr. D. Asher, Jan. 1871, pp. 312-332. An Exegesis of, by Oswald Dawson. Jollmal of Seicnce, vol. 6 , 3rd series, 1884 , pp. 725738.

- Application of, to Flowers and the Insects which visit them. American Naturalist, by E. Muller, vol. 5, 1871, pp. 271. 297.

- Attitude of Working Natural. ists towards. Nation, by $\Lambda$ sa Gray, vol. 17, 1873, pp. 258. 261 ; reprinted in Darwiniana, by Asa Gray, 1876.

Bateman on. Dublin Review, vol. 31, N.S., 187s. pp. 139152. - Nation, by J. Fiske, vol. $27,1878, \mathrm{pn} .367,368$.

Creclibility of. Jour. of the Trans. of the Vietoria Institute, by Geo. Warington, vol. 2, 1867, pp. 39-62.

Reply to preeeding Paper, by James Reddie, vol. 2, 1567, pp. 63-85.

pp. $85-125$.

Discussion on same,

Dangers of. Popular Scienee Montlily, rol. 15, 1879, pp. 6s-71.

- Dectuction from. Nature, by W. Stanley Jerons, vol. 1, 1870, P. 231, 232.

Develomment Theory in. Das A usland, No. 14, 1863, pp. 325. 331.

Difficulties of. Quarterly Journal of Seience, vol. 12, 1875, rip. 322-336. 
Darwin, Charles Robert.

Ethical Aspect of. Canadian Monthly, by J. Watson, vol. 11, 1878, pp. 638.644.

- Fallacies of, Dr. Eree on. Dublin Review, vol. 23, N.S., 1874, pp. 240-246. - Nature, by Alfred R. Wallace, vol. 5, 1872, pp. 237.239.

- Fiske on. Nature, vol. 20, $1879, \mathrm{pp} .575,576$.

Frolie in Space. Iakeside, by J. M. Binckley, vol. 8, pp. 416 , etc.

Gray's Darwiniana. Nation, by H. W. Holland, vol. 23, 1876, pp. 358, 359.

Great Difficulty of. Nature, by L. S. Beale, vol. 5, 1872, pp. 63, 64 .

Hacckel's Reply to Virehow. Nation, by H. 'I'. Finck, vol. 28, 1879, l'p. 320-322.

-ITistoric Development of. Baptist Quarterly, by G. IV. Samson, vol. 11, 1877, pp. 2933.

Infallibility in. Dublin University Magazine, vol. 5, N.S., 1880, pp. 641-669.

in Germany. North American

Revicw, by C. L. Brace, vol. 110, 1870, pp. 284-299.-Wation, by C. Wright, vol. 21, 1875, pl. 168-170. -Anthropological Review, vol. 6, 1868, pp. 21-26. in Mrorals. Canadian Monthly, by J. A. Allen, vol. 11, 1878, pp. 490-501.--Theological Review, by F. P. Cobbe, vol. 8,1871, pp. 167-192.

-Its Value as a Cosmologieal Theory. Cape Monthly Magrazine, by the Rev. J. 'Turnbull, vol. 11, N.S. 1875 , pp. 184-188 and $212-225$.
Darwin, Charles Robert.

-Last Attack on. Nature, by

A. R. Wallace, vol. 6, 1872, pp. 237-239.

Latest Development of. Lon. don Quarterly lieview, vol. 57, 1882, pl). 371-391.

Mrissing Links in. Gentle. man's Magazine, by Androw Wilson, 1879, pp. 298-320.

Mivart on. Dublin Review, vol. 16, N.S., $1871, p p, 482$. 486.

IIy Cousin the Gorilla. Tins. ley's Magazine, vol. 8, 1871, pp. $395-399$, and vol, 9, pp. 135140.

New York "Nation" on, in Germany. Popular Science Monthly, vol. 8, 1876, pp. 235240.

- Iiclation of, to other branehes of Science. Longman's Magazine, by Robert S. Bell, vol. 3, 1884, pp. 76-92.

- Ricliculous. Lutheran Quarterly, by W. Streissgutli, vol. 5, pl. 404, etc.

Scienee ayainst. University Quarterly, by J. Moore, vol. 35, pp. 186, etc.

Some Popular Misconceptions of. Proc. of the Literary and Phil. Soc. of Liverpool, by S. Fletcher-Williams, No. 36, 1882, pp. 133-156.

Strictures on. Anthropological Journal, by H. H. Howorth, vol. 2,1873 , pl. 21.40 ; vol. 3 , pl. $208-229$; vol. 4, pp. 101 . 121.

Studies in. American Church Review, by J. F. Garrison, vol. 27, 1875, pp. 197-218.

- - tested by recent rescarches in language. Jour. of the Trans. of the Victoria Institute, by 
Darwin, Charles Robert.

Fred. Bateman, vol. 7, 1874, pp. 73-95.

Theological Import of. Christian Observer, vol, 73, p. 623 , etc. Trizmph of. North American Review, by J. Fiske, vol. 124, 1877, pp. 90-106.

-True and False in. Journal of Specrlative l'hilosophy, by E. von Hartmann, vol. 11,
Darwin, Charles Robert.

1877, pp. 244-251, and 392399 ; vol. 12 , pp. 138-145; vol. 13, pp. 139-150.

- versus Philosophy. Southern Review, vol. 13, 1873, pp. 253. 273.

What is? Nation, by A. Gray, vol. 18, 1874, pp. 348. 351 ; reprinted in Darwiniana, by Asa Gray, 1876.

\section{IV.-CHRONOLOGICAL LIST OF WORKS.}

Journal of Researclies

Structure and Distribution of Coral Reefs

Geolocrical Observations on the Volcanic Islands visited during the Voyage of II.M.S. Beagle .

Geologrical Observations on South America

Monograpl on the Fossil Lepalidie

1839

1844

Monograph of the Cirripedia ${ }^{2}$ on the Fossil Palanicla

On the Origin of Species . On the Various Contrivances by which Orchids are fertilised.

1842

1846

1851

$1851-54$ 1854
Movements and Habits of Climbing Plants . . The Variation of Animals and Plants under Domestication . • . 1868 The Descent of Man . . 1871 The Expression of the Emotions . . . 1872 Insectivorous Plants . • 1875 The Effects of Cross and Self-Fertilisation in the Vegetable Kingdom 1876 The Different Forms of Flowers on Plants of the same Species

1865 1859

The Power of Mlovement in Plants. . 1850

The Formation of Vecretable Mould through the 1862 



\section{THE SCOTT LIBRARY.}

Cloth, Uncut Edges, Gilt Top. Price 1s. 6d. per Volume.

\section{VOLUMES ALREADY ISSUED-}

I MALORY'S ROMANCE OF KING ARTHUR AND TIIE Quest of the Holy Grail. Edited by Ernest Rhys.

2 THOREAU'S WALDEN. WITH INTRODUCTORY NOTE by Will H. Dircks.

3 THOREAU'S "WEEK." WITH PREFATORY NOTE BY Will H. Dircks:

4 TIOREAU:S ESSAYS. EDITED, WITH AN INTROduction, by Will H. Dircks.

5 CONFESSIONS OF AN ENGLISH OPIUM-EATER, ETC. by Thomas De Quincey. With Introductory Note by William Sharp.

6 LANDOR'S IMAGINARY CONVERSATIONS. SELECTED, with Introduction, by Havelock Ellis.

7 PLUTARCH'S LIVES (LANGHORNE). WITH INTRO. ductory Note by B. J. Snell, M.A.

S BROWNE'S REIIGIO MEDICI, ETC. WITH INTROduction by $J$. Addington Symonds.

9 SHELLEY:S ESSAYS AND LETTERS. EDITED, WITH Introductory Note, by Ernest Rhys.

Io SWIFT'S PROSE WRITINGS. CHOSEN AND ARRANGED, with Introduction, by Walter Lewin.

I I MY STUDY WINDOWS. BY JAMES RUSSELL LOWELL. With Introduction by R. Garnett, LL.D.

I2 LOWELL'S ESSAYS ON THE ENGLISH POETS. IVITII a new Introduction by Mr. Lowell.

I3 TIIE BIGLOW PAPERS. BY JAMES RUSSELL LOWELL. With a l'refatory Note by Ernest Rhys.

I4 GREAT ENGLISH PAINTERS. SELECTED FROM C'unningham's Lices. Edited by William Sharp.

London: Walter ScotT, Limited, Paternoster Square. 


\section{THE SCOTT LIBRARY-continued.}

I5 BYRON'S LETTERS AND JOURNALS. SELECTED, with Introduction, by Mathilde Blind.

I6 LEIGH HUNT'S ESSAYS. WITH INTRODUCTION AND Notes by Arthur Symons.

17 LONGFELLOW'S "HYPERION," "KAVANAGI," AND "The Trouveres." With Introduction by W. Tirebuck.

I8 GREAT MUSICAL COMPOSERS. BY G. F. FERRIS. Edited, with Introduction, by Mrs. William Sharp.

19 THE MEDITATIONS OF MARCUS AURELIUS. EDITED by Alice Zimmern.

20 TIE TEACHING OF EPICTETUS. TRANSLATED FROM the Greek, with Introduction and Notes, by T. W. Rolleston.

21 SELECTIONS FROM SENECA. WITH INTRODUCTION by Walter Clode.

22 SPECIMEN DAYS IN AMERICA. BY WALT WHITMAN. Revised by the Author, with fresh Preface.

23 DEMOCRATIC VISTAS, AND OTHER PAPERS. BY Walt Whitman. (Published by arrangement with the Autlior.)

24 WHITE'S NATURAL HISTORY OF SELBORNE. WITH a Preface by Richard Jefferies.

25 DEFOE'S CAPTAIN SINGLETON. EDITED, WITH Introduction, by $\mathrm{H}$. Halliday Sparling.

26 MAZZINI'S ESSAYS: LITERARY, POLITICAL, AND Religious. With Introduction by William Clarke.

27 PROSE WRITINGS OF HEINE. WITH INTRODUCTION by Haveloek Ellis.

28 REYNOLDS'S DISCOURSES. WITH INTRODUCTION by Helen Zimmern.

29 PAPERS OF STEELE AND ADDISON. EDITED BY Walter Lewin.

30 BURNS'S LETTERS. SELECTED AND ARRANGED, with Introduction, by J. Logie Robertson, M.A.

3 IOLSUNGA SAGA. William Morris. With INTROduction by H. II. sparling.

London: Walter SCotr, Limited, Paternoster Square. 


\section{THE SCOTT LIBRARY-continued.}

32 SARTOR RESARTUS. BY THOMAS CARLYLE. IVITH Introduction by Eruest Rhys.

33 SELECT WRITINGS OF EMERSON. WITH INTRO. duction by Percival Clubbb.

34 AUTOBIOGRAPHY OF LORD HERBERT. EDITED, with an Introduction, by Will H. Dircks.

35 ENGLISH PROSE, FROM MAUNDEVILLE TO Thackeray. Chosen and Edited by Arthur Galton.

36 THE PILLARS OF SOCIETY, AND OTHER PLAYS. BY Henrik Ibsen. Edited, with an Introduction, by Havelock Ellis.

37 IRISH FAIRY AND FOLK TALES. EDITED AND Selected by W. B. Yeats.

38 ESSAYS OF DR. JOHNSON, WITH BIOGRAPHICAL Introduction and Notes by Stuart $J$. Reid.

39 ESSAYS OF WILLIAM HAZLITT. SELECTED AND Edited, with Introduction and Notes, by Frank Carr.

40 LANDOR'S PENTAMERON, AND OTHER IMAGINARY Conversations. Edited, with a Preface, by $\mathrm{H}$. Ellis.

AI POE'S TALES AND ESSAYS. EDITED, WITH INTROduction, by Ernest Rhys.

42 VICAR OF WAKEFIELD. BY OLIVER GOLDSMITH. Edited, with Preface, by Eruest Rhys.

43 POLITICAL ORATIONS, FROM WENTWORTH TO Macaulay. Edited, with Introduction, by William Clarke.

44 THE AUTOCRAT OF THE BREAKFAST-TABLE. BY Oliver Wendell Holmes.

45 THE POET AT THE BREAKFAST-TABLE. BY OLIVER Wendell Holmes.

46 THE PROFESSOR AT THE BREAKFAST-TABLE. BY Oliver Wendell Holmes.

47 LORD CHESTERFIFLD'S LETTERS TO HIS SON. Selected, with Introduction, by Charles Sayle.

48 STORIES FROM CARLETON. SELECTED, WITH INTROduction, by W. Yeats.

London: Walter Scotr, Limited, Paternoster Square. 


\section{THE SCOTT LIBRARY-continued.}

49 JANE EYRE. BI" CHARLOTTE BRONTË. EDITED BI Clement K. Shorter.

50 ELIZABETIAN ENGLAND. EDITED BY LOTHROP Withington, with a Preface by Dr. Furnivall.

5I THE PROSE WRITINGS OF THOMAS DAVIS. EDITED by T. W. Rolleston.

52 SPENCE'S ANECDOTES. A SELECTION. EDITED, with an Introduction and Notes, by John Underhill.

53 MORE'S UTOPIA, AND LIFE OF EDWARD V. EDITED, syith an Introduction, by Maurice Adams.

5+ SADI'S GULISTAN, OR FLOWER GARDEN. TRANS. lated, with an Essay, by James Ross.

55 ENGLISH FAIRY AND FOLK TALES. EDITED BY E. Sillney Hartland.

56 NORTIERN STUDIES. BY EDMUND GOSSE. WITH a Note by Ernest Rhys.

57 EARLY REVIEWS OF GREAT WRITERS. EDITED BY E. Stevenson.

5S. 1 RISTOTLE'S ETHICS. WITH GEORGE HENRY Lewes's Essay on A ristotle pretixed.

59 LANDOR'S PERICLES AND ASPASI. EDITED, WITH an Introduction, by Havelock Eillis.

60 ANNALS OF TACITUS. THOMAS GORDON'S TRANSlation. Edited, with an Introduction, by Arthur Galton.

6I ESSAIS OF ELIA. BY CHARLES LAMB. EDITED, with an Introduction, by Ernest Rhys.

62 LALZAC'S SHORTER STORIES. TRANSLATED BY William Wilson and the Count Stenbock.

63 COMEDIES OF DE MUSSET. EDITED, WITI AN Introductory Note, by S. L. Giwynn.

64 CORAL REEFS. BY CHARLES DARWIN. EDITED, with an Introduction, by Dr. J. W. Williams.

65 SHERIDAN'S PLAYS. EDITED, WITH AN INTRO. duction, by Rudolf Dircks.

London: Walter SCotT, Lcmeter, Patemoster Square. 


\section{THE SCOTT LIBRARY-continued.}

66 OUR VILLAGE. BY MISS MITFORD. EDITED, WITI an Introduction, by Ermest Rhys.

67 MASTER IIUMPHREY'S CLOCK, AND OTHER STORIES. By Charles Dickens. With Introduction by Frank T. Marzials.

68 TALES FROM WONDERLAND. BI RUDOLPI Baumbacl. Translated by Helen B. Dole.

69 ESSAYS AND PAPERS BY DOUGLAS JERROLD. EDITET by Walter Jerrold.

70 VINDICATION OF THE RIGHTS OF WOMAN. EY Mary Wollstonecraft. Introduction by Mrs. E. Robins Pemnell.

7I "THE ATHENIAN ORACLE." A SELECTION. EDITED by John Underhill, with Prefatory Note by Walter Besant.

72 ESSAIS OF SAINTE-BEUVE. TRANSLATED AND Edited, with an Introduction, by Elizabeth Lee.

73 SELECTIONS FROM PLATO. FROM THE TRANS. lation of Sydenham and Taylor. Edited by T. W. Rolleston.

74 IIEINE'S ITALIAN TRAVEL SKETCHES, ETC. TRANS. lated by Elizabeth $A$. Sharp. With an Introduction from the French of Theophile Giantier.

75 SCHILLER'S MAID OF ORLEANS. TRANSLATEI, with an Iutroduction, by Major-General Patrick Maxwell.

76 SELECTIONS FROM SYDNEY SMITH. EDITED, WITH an Introduction, by Ernest Rhys.

77 TILE NEW SPIRIT. BY HAVELOCK ELLIS.

iS TIE BOOK OF MARVELLOUS ADVENTURES. FROM the "IIorte d'Arthur:" Edited by Ernest Rhys. [This, together with No. 1, forms the complete "Morte d'Artliur."]

79 ESSAYS AND APIHORISMS. BY SIR AKTHUR IHELPS. With an Introduction by E. A. Helps.

SO ESSAYS OF NONTAIGNE. SELECTED, WITI A Prefatory Note, by Percival Chubb.

SI THE LUCK OF BARRY LYNDON. BY I. M. Thackeray. Edited by F. T. Marzials.

S2 SCHILLER'S WILLIAM TELL. TRANSLATED, WITH an Introduction, by Major-(ieneral Patrick Mlaxwell.

Loudon: WaITER Scort, IMMI'TE, Paternoster Square. 


\section{THE SCOTT LIBRARY-continued.}

83 CARLYLE'S ESSAYS ON GERMAN LITERATURE。 With an Introduction by Ernest Rhys.

84 PLAYS AND DRAMATIC ESSAYS OF CHARLES LAMB. Edited, with an Introduction, by Rudolf Dircks.

85 THE PROSE OF WORDSWORTH. SELECTED AND Edited, with an Introduction, by Professor William Kninht.

86 ESSAYS, DIALOGUES, AND THOUGHTS OF COUNT Giacomo Leopardi. Translated, with an Introduction and Notes, by Major-General Patrick Maxwell.

87 THE INSPECTOR-GENERAL. A RUSSIAN COMEDY. By Nikolai V. Gogol. Translated from the original, with an Introduction and Notes, by Arthur A. Sykes.

88 ESSAYS AND APOTHEGMS OF FRANCIS, LORD BACON. Edited, with an Introduction, by John Buchan.

89 PROSE OF MILTON. SELECTED AND EDITED, WITH an Introduction, by Richard Garnett, LL.D.

90 THE REPUBLIC OF PLATO. TRANSLATED BY Thomas Taylor, with an Introduction by Theodore Wratislaw.

9I PASSAGES FROM FROISSART. WITH AN INTRO. duction by Frank T. Marzials:

92 THE PROSE AND TABLE TALK OF COLERIDGE. Edited by Will H. Dircks.

93 HEINE IN ART AND LETTERS. TRANSLATED BY Elizabeth A. Sharp.

94 SELECTED ESSAYS OF DE QUINCEY. WITH AN Introduction by Sir George Douglas, Bart.

95 VASARI'S LIVES OF ITALIAN PAINTERS. SELECTED and Prefaced by Havelock Ellis.

96 LAOCOON, AND OTHER PROSE WRITINGS OF LESSING. A new Translation by W. B. Rönnfeldt.

97 PELLEAS AND MELISANDA, AND THE SIGHTLESS. Two Plays by Maurice Maeterlinck. Translated from the French by Iaurenoe Alma Tadema.

98 THE COMPLETE ANGLER OF WALTON AND COTTON. Edited, with an Introduction, by Charles Hill Dick.

London: Walter ScotT, Limited, Paternoster Square. 


\section{THE SCOTT LIBRARY-continued.}

99 LESSING'S NATHAN THE WISE. TRANSLATED BY Major-General Patrick Maxwell.

IOO THE POETRY OF THE CELTIC RACES, AND OTHER Essays of Ernest Renan. Translated by W. G. Hutchison.

IOI CRITICISMS, REFLECTIONS, AND MAXIMSOF GOETHE. Translated, with an Introduction, by W. B. Rönnfeldt.

IO2 ESSAYS OF SCFOPENHAUER. TRANSLATED BY Mrs. Rudolf Dircks. With an Introduction.

I03 RENAN'S LIFE OF JESUS. TRANSLATED, WITH AN Introduction, by William G. Hutchison.

IO4 THE CONFESSIONS OF SAINT AUGUSTINE. EDITED, with an Introduction, by Arthur Syroons.

105 THE PRINCIPLES OF SUCCESS IN LITERATURE. By George Henry Lewes. Edited, with an Introduction, by T. Sharper Knowlson. 


\section{LIBRARY OF HUMOUR}

Cloth Elegant, Large Crown 8vo, Price $3 / 6$ per vol.

VOLUMES ALREADY ISSUED.

THE HUMOUR OF FRANCE. Translated, with an Introduction and Notes, by Elizabeth Lee. With numerous Illustrations by Paul Frénzeny.

THE HUMOUR OF GERMANY. Translated, with an Introduction and Notes, by Hans Müller-Casenov. With numerous Illustrations by C. E. Brock.

THE HUMOUR OF ITALY. Translated, with an Introduction and Notes, by A. Werner. With 50 Illustrations and a Frontispiece by Arturo Faldi.

THE HUMOUR OF AMERICA. Selected with a copious Biographical Index of American Humorists, by James Barr.

THE HUMOUR OF HOLLAND. Translated, with an Introduction and Notes, by A. Werner. With numerous Illustrations by Dudley Hardy.

THE HUMOUR OF IRELAND. Selected by D. J. O'Donoghue. With numerous Illustrations by Oliver Paque.

THE HUMOUR OF SPAIN. Translated, with an Introduction and Notes, by S. Taylor. With numerous Illustrations by $\mathrm{H}$. R. Millar.

THE HUMOUR OF RUSSIA. Translated, with Notes, by E. L. Boole, and an Introduction by Stepniak. With 50 Illustrations by Paul Frénzeny.

THE HUMOUR OF JAPAN. Translated, with an Introduction, by A. M. With Illustrations by George Bigot (from Drawings made in Japan). [In preparation.

London: Walter Scott, Limited, Paternoster Square. 


\section{IBSEN'S PROSE DRAMAS.}

\section{EDITED BY WILLIAM ARCHER.}

Complete in Five Vols. Crown 8vo, Cloth, Price $3 / 6$ each. Set of Five Vols., in Case, 17/6: in Half Morocco, in Case, 32/6.

"We seem at last to be shown men and women as they are; and at first it is more than we can endure. . . . All Ibsen's char acters speak and act as if they zere hypnotised, and under their creator's imperious demand to reveal themselves. There never was such a mirror held up to nature before: it is 100 terrible. . . . Yet we must return to Ibsen, with his remorseless surgery, his remorseless electric-light, until ave, too, have groiun strong and learned to face the naked-if necessary, the flayed and bleeding-reality."-SPEAKER (London).

VOL. I. "A DOLL'S HOUSE" "THE LEAGUE OF YOUTH," and "THE PILLARS OF SOCIETY." With Portrait of the Author, and Biographical Introduction by WILLIAM ARCHLR.

VOL. II. "GHOSTS," "AN ENEMY OF THE PEOPIL," and "THE WILD DUCK." With an Introductory Note.

Vol. III. "LADY INGER OF ÖSTRÅT," “THE VIKINGS AT HELGELAND," "THE PRETENDERS." With an Introductory Note and Portrait of Ibsen.

VOL. IV. "EMPEROR AND GALILEAN." With an Introductory Note by WILLIAM ARCHER.

VOL. V. "ROSMERSHOLM," "THE LADY FROM THE SEA," "HEDDA GABLER." Transiated by WILLIAM ARCHER. With an Introductory Note.

The sequence of the plays in each volume is chronological; the complete set of volumes comprising the dramas thus presents thein in chronological order.

"The art of prose translation does not perhaps enjoy a very high literary status in England, but we have no hesitation in numbering the present version of Ibsen, so far as it has gone (Vols. I. and II.), among the very best achievements, in that kind, of our generation."-Acadlemy.

"We have seldom, if ever, met with a translation so absolutely idiomatic."-Glas.sout Herald.

London: Walter Scott, Limited, Paternoster Square. 
COMPACT AND PRACTICAL.

In Limp Cloth; for the Pocket. Price One Shilling.

\section{THE EUROPEAN}

\section{CONVERSATION BOOKS.}

\section{FRENCH \\ ITALIAN \\ SPANISH GERMAN \\ NORWEGIAN}

\section{CONTENTS.}

Hints to Travellers-Everyday Expressions-Arriving at and Leaving a Railway Station-Custom House Enquiries-In a Train-At a Buffet and Restaurant-At an Hotel-Paying an Hotel Bill-Enquiries in a Town-On Board Ship-Embarking and Disembarking-Excursion by Carriage-Enquiries as to Diligences-Enquiries as to Boats-Engaging Apartments-Washing List and Days of Week-Restaurant VocabularyTelegrams and Letters, etc., etc.

The contents of these little handbooks are so arranged as to permit direct and immediate reference. All dialogues or enquiries not considered absolutely essential have been purposely excluded, nothing being introduced which might confuse the traveller rather than assist him. A few hints are given in the introduction which will be found valuable to those unaccustomed to foreign travel.

London: Walter Scott, Limited, Paternoster Square. 
Crown 8vo, about 350 pp. each, Cloth Cover, 2/6 per Vol.; Half-Polished Morocco, Gilt Top, 5s.

\section{Count Tolstoy's Works.}

The following Volumes are already issued-

A RUSSIAN PROPRIETOR.

THE COSSACKS.

IVAN ILYITCH, AND OTHER

STORIES.

MY RELIGION.

LIFE.

MY CONFESSION.

CHILDHOOD, BOYHOOD,

YOUTH.

THE PHYSIOLOGY OF WAR.

ANNA KARÉNINA. $3 / 6$.

WHAT TO DO?

WAR AND PEACE. (4 vols.)

THE LONG EXILE, ETC.

SEVASTOPOL.

THE KREUTZER SONATA, AND

FAMILY HAPPINESS.

THE KINGDOM OF GOD IS WITHIN YOU.

WORK WHILE YE HAVE THE LIGHT.

THE GOSPEL IN BRIEF.

Uniform with the above-

IMPRESSIONS OF RUSSIA. By Dr. Georg BRANDES.

Post 4to, Cloth, Price Is.

PATRIOTISM AND CHRISTIANITY.

To which is appended a Reply to Criticisms of the Work. By Count Tolstoy.

\section{I/- Booklets by Count Tolstoy.}

Bound in White Grained Boards, with Gilt Lettering.

WHERE LOVE IS, THERE GOD

IS ALSO.

THE TWO PILGRIMS.

WHAT MEN LIVE BY.

THE GODSON.

IF YOU NEGLECT THE FIRE, YOU DON'T PUT IT OUT. WHAT SHALL IT PROFIT A MAN?

\section{2/- Booklets by Count Tolstoy.}

NEW EDITIONS, REVISED.

Small 12mo, Cloth, with Embossed Design on Cover, each containing Two Stories by Count Tolstoy, and Two Drawings by H. R. Millar. In Box, Price 2s, each.

Volume 1. containsWHERE LOVE IS, THERE GOD IS ALSO.

THE GODSON.

Volume II. containsWHAT MEN LIVE BY. WHAT SHALL IT PROFIT A MAN?
Volume III. containsTHE TWO PILGRINS. IF YOU NEGLECT THE FIRE, YOU DON'T PUT IT OUT.

Volume IV. containsMASTER AND MAN.

Volume V. containsTOLSTOY'S PARABLES.

London: Walter Scott, Linited, Paternoster Square. 


\section{NEW ENGLAND LIBRARY. GRAVURE EDITION.}

PRINTED ON ANTIQUE PAPER. 2s. 6d. PER VOL. Each Volume with a Frontispiece in Photogravure.

\section{BY NATHANIEL HAWTHORNE.}

THE SCARLET LETTER.

THE HOUSE OF THE SEVEN GABLES.

THE BLITHEDALE ROMANCE.

TANGLEWOOD TALES.

TWICE-TOLD TALES.

A WONDER-BOOK FOR GIRLS AND BOYS.

OUR OLD HOME.

MOSSES FROM AN OLD MANSE.

THE SNOW IMAGE.

TRUE STORIES FROM HISTORY AND BIOGRAPIY. THE NEW ADAM AND EVE.

LEGENISS OF THE PROVINCE HOUSE.

\section{By OLIVER WENDELL HOLMES.}

THE AUTOCRAT CF THE BREAKFAST-TABLE. THE PROFESSOR AT THE BREAKFAST-TABLE. THE POET AT THE BREAKFAST-TABLE. ELSIE VENNER.

\section{By HENRY THOREAU.}

ESSAYS AND OTHER WRITINGS. WALDEN; OR, LIFE IN THE WOODS. A WEEK ON THE CONCORD.

London: Walter Scott, Limited, Paternoster Square. 
Crown Svo, Cloth, 3s. 6d. each; some vols., 6s.

\section{THE}

\section{Contemporary Science Series.}

Edited by HAVELOCK ELLIS.

Illustrated Volumes containing between 300 and 400 pp.

EVOLUTION OF SEX. By Prof. GedDEs and THOMSON. ELECTRICITY IN MODERN LIFE. By G. W. DE TUNZEL. MANN.

THE ORIGIN OF THE ARYANS. By Dr. TAYLOR.

PHYSIOGNOMY AND EXPRESSION. By P. MANTEGAZZA. EVOLUTION AND DISEASE. By J. B. SUTTON.

THE VILLAGE COMMUNITY. By G. L. GOMME. THE CRIMINAL. By HAVELOCK ELLIS. SANITY AND INSANITY. By Dr. C. MERCIER. HYPNOTISM. By Dr. AlBERT MOLL (Berlin).

MANUAL TRAINING. By Dr. WOODWARD (St. Louis). SCIENCE OF FAIRY TALES. By E. S. HARTLAND. PRIMITIVE FOLK. By ElIE RECLUS EVOLUTION OF MARRIAGE. BY LETOURNEAU. BACTERIA AND THEIR PRODUCTS. Dr. WOODHEAD. EDUCATION AND HEREDITY. By C. M. GUYAU. THE MAN OF GENIUS. By Prof. LOMBRoso. THE GRAMMAR OF SCIENCE. By Prof. PEARSON. PROPERTY : ITS ORIGIN. By CH. LETOURNEAU. VOLCANOES PAST AND PRESENT. By Prof. HULl. PUBLIC HEALTH PROBLEMS. By Dr. J. F. SYKES. MODERN METEOROLOGY. By FRANK WALdO, Ph.D. THE GERM-PLASM. By Professor WEISMANN. 6 s. THE INDUSTRIES OF ANIMALS. By F. HOUSSAY. MAN AND WOMAN. By HAVELOCK Ellis. 65. MODERN CAPITALISM. By JOHN A. HOBSON, M.A. THOUGHT-TRANSFERENCE. By F. PODMORE, M.A. COMPARATIVE PSYCHOLOGY. By Prof. C. L. MORGan. 6s. THE ORIGINS OF INVENTION. By O. T. MASON. THE GROWTH OF THE BRAIN. By H. H. DONALDSON. EVOLUTION IN ART. By Prof. A. C. HADDON. HALLUCINATIONS AND ILLUSIONS. By E. PARISH. 6s. PSYCHOLOGY OF THE EMOTIONS. By Prof. RiBot. 6 s. THE NEW PSYCHOLOGY. By Dr. E. W. SCRIPTURE. 6 s. SLEEP: Its Physiology, Pathology, Hygiene, AND Psychology. By Marie DE MANACEÏNL.

THE NATURAL HISTORY OF DIGESTION. By A. LOCKhaRT GillesPie, M.D., F.R.C.P. ED., F.R.S. ED. $6 \mathrm{s.}$

DEGENERACY: Its CaUses, Signs, and Results. By Prof.

EUgene S. TALbot, M.D., Chicago. $6 s$. 


\section{SPECIAL EDITION OF THE \\ CANTERBURY POETS.}

Square 8vo, Cloth, Gilt Top Elegant, Price 2s. Each Volume with a Frontispiece in Photogravure. CHRISTIAN YEAR. With Portrait of John Keble.

LONGFELLOW. With Portrait of Longfellow.

SHELLEY. With Portrait of Shelley.

WORDSIVORTH. With Portrait of Wordsworth.

WHITTIER. With Portrait of Whittier.

BURNS. Songs ) With Portrait of Burns, and View of "Tho BURNS. Poems $\}$ Auld Brig o' Dooll."

IKEATS. With Portrait of Keats.

E.MERSON. With Portrait of Emerson.

SONNETS OF THIS CENTURY. Portrait of D. G. Rosselli. WHITMAN. With Portrait of Whitman.

IO VE LEITERS OF A VIOLINIST. Portrait of Eric Mackay. SCOTT. Lady of the Lake, With Portrait of Sir Walter Scott, etc. $\}$ and View of "The Silver SCOT'T. Marmion, etc. $\int$ Strand, Loch Katrine."

CHILDREN OF THE POETS. With an Engraving of "Tho Orphans," by Gainsborough.

SONNETS OF EUROPE. With Portrait of J. A. Symonds. SYDNEY DOBELL. With Portrait of Sydney Dobell.

IHERRICK. With Portrait of Herrick.

BALLADS AND RONDEAUS. Portrait of W. E. Henley. IRISH MINSTRELSY. With Portrait of Thomas Davis.

PARADISE IOST. With Portrait of Milton.

FAIRY MUSIC. Engraving from Drawing by C. E. Brock.

GOLDEN TREASURY. With Engraving of Virgin Mother.

AMERICAN SONNETS. With Portrait of J. R. Lowell.

IMITATION OF CHRIST. With Engraving, "Ecce Homo." PAINTER POETS. With Portrait of Walter Crane.

WOMEN POETS. With Portrait of Mrs. Browning.

POEMS OF HON. RODEN NOEL. Portrait of Hon. R. Noel. AMERICAN HUMOROUS VERSE. Portrait of Mark Twain. SONGS OF FREEDOM. With Portrait of William Morris. SCOTTISH MINOR POETS. With Portrait of R. Tannahill. CON'TEMPORARY SCOTTISH VERSE. With Portrait of Robert Louis Stevenson.

PARADISE REGAINED. With Portrait of Milton.

CAVALIER POETS. With Portrait of Suckling. HUMOROUS POEMS. With Portrait of Hood.

HERBERT. With Portrait of Herbert.

POE. With Portrait of Poe.

OWEN MEREDI'H. With Portrait of late Lord Lytton. 
LOVE LYRICS. With Portrait of Raleigh.

GERMAN BALLADS. With Portrait of Schiller.

CAMPBELL. With Portrait of Campbell.

CANADIAN POEMS. With View of Mount Stephen.

EARLY ENGLISH POETRY. With Portrait of Earl of Surrey.

ALLAN RAMSAY. With Portrait of Ramsay.

SPENSER. With Portrait of Spenser.

CHATTERTON. With Engraving, "The Death of Chatterton."

COWPER. With Portrait of Cowper.

CHA UCER. With Portrait of Chaucer.

COLERIDGE. With Portrait of Coleridge.

POPE. With Portrait of Pope.

$\left.\begin{array}{l}\text { BYRON. Miscellaneous } \\ \text { BYRON. Don Juan }\end{array}\right\}$ With Portraits of Byron.

JACOBITE SONGS. With Portrait of Prince Charlie.

BORDER BALLADS. With View of Neilpath Castle.

AUSTRALIAN BALLADS. With Portrait of A. L. Gordon.

HOGG. With Portrait of Hogg.

GOLDSMITH. With Portrait of Goldsmith.

MOORE. With Portrait of Moore.

DORA GREEN ELL. With Portrait of Dora Greenwell.

BLAKE. With Portrait of Blake.

POEMS OF NATURE. With Portrait of Andrew Lang

PRAED. With Portrait.

SOUTHEY. With Portrait.

HUGO. With Portrait.

GOETHE. With Portrait.

BERANGER. With Portrait.

HEINE. With Portrait.

SEA MUSIC. With View of Corbière Rocks, Jersey.

SONG.TIDE. With Portrait of Philip Bourke Marston.

LADY OF LY()NS. With Portrait of Bulwer Lytton.

SHAKESPEARE: Songs and Sonnets. With Portrait.

BEN JONSON. With Portrait.

HORACE. With Portrait.

CRABBE With Portrait.

CRADLE SONGS. With Engraving from Drawing by T. E. Macklin.

BALLADS OF SPORT.

Do.

do.

MATTHEW AR NOI.D. With Portrait.

AUSTIN'S DAYS OF THE YEAR. With Portrait.

CLOUGH'S BOTHIL, and other Poems. With View.

BROWNING'S Pippa Passes, etc.

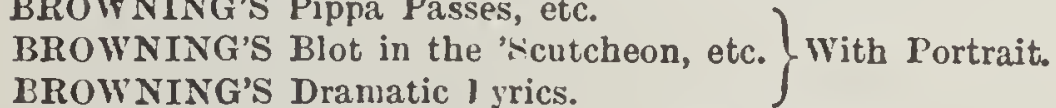

MACKAY'S LOVER'S MISSA I. With Portrait.

IKIRKE WHITE'S POFMI: With Portrait.

LYRA NICOTIANA. With Portrait.

AURORA LEIGH. With Portrait of E. B. Browning. 


\section{Great Writers.}

A NEW SERIES OF CRITICAL BIOGRAPHIE.3.

Edited by E. Robertson and F. T. MARzIALS.

Clotl, Uncut Edges, Gilt Top. Price $1 / 6$.

Longfellow By Professor Hric. . Robertinn

Coleridge . . . . . . By Hall Caine

Dickens : : ij Frank T. Marzials

Dante Gabriel Rossetti . . . By J. Knight

Samuel Johnson - . By Colonel F. Grant

Darwin . . . By G. T. Bettany

Charlotte brontio : - . - By A. Birrell

Carlyle . . . . liy R. (iarnett, LL. D).

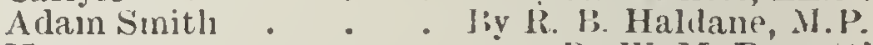

Kieats . • . . • JiY W. Russetti

Shelley . • • • . Ijy Willian sharp

Smollett - • . . - By David Hanlay

Goldsmith . . . . By Austin Jobson

Scott - . . . By Professor Yonge

Burns . . . . By Professor Blackie

Victor Hugo . . . My Frank T. Marzials

Emerson . . . . Hi R. Garnett, Ll, D.

Goethe . . . By James Sime

Congreve - . . . By Ednund Gosse

Bunyan - . . . By Canon Venables

Crabbe . . . . . Ey T. E. Kehbel

Heine + . . . . By Wrilliam Sharp

Mill • • . . . . By W. L. Conrtney

Schiller - . . By Henry W. Nerinson

Marryat : • . . - By David Hamiay

Iessing - . . . . By T W. Rollestun

Milton . . . By $\dot{\mathrm{R}}$ (jarnett, LL. J).

Balzac . . . By Frederick Wedmore

George Eliot - . . - By Oscar Browning

Jane Austen . . . . By Goldwin Smitl

Browning . . . . By William Sharp

Byron . . . . By Hion. Roden Nisel

Hawthorne - . . By IIoncure D. Conway

Schopenhaner - . . By Professor Wallice

Sheridan . . . By bloyd Sanders

Thackeray. . By II. Merivale anil F. T. Marzials

Cervantes : . . By H. E. Wutts

Voltaire - • . . By Francis Espinasso

Leigh Hunt . . . by Cosmo Monkhouse

Whittier . . . . By IV. J. Iinton

Renan - . . . By Francis Espinasso

Thoreau . . . . . By H. S. Salt

A Complete Bibliography to each Volnme, by J. P. A.vdirson, British Museum, London.

Library Ldition of "Great Writers," Demy svo, 2/6. 



